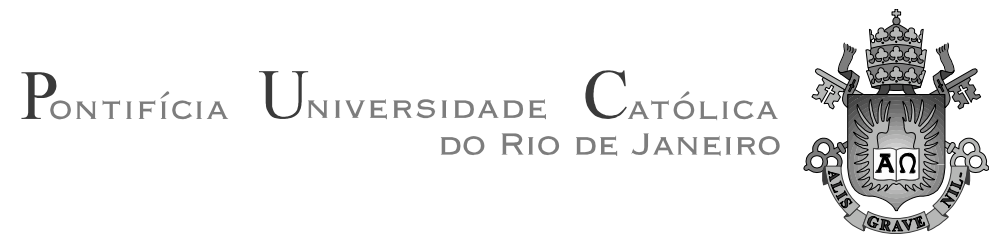

Maikel da Silveira

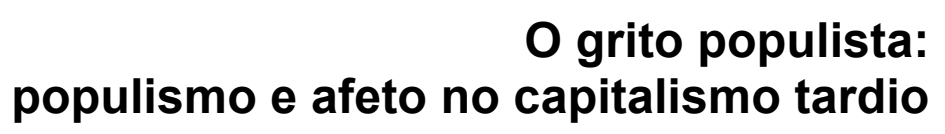

Dissertação de Mestrado

Dissertação apresentada ao Programa de Pós-graduação em Filosofia da PUC-Rio como requisito parcial para a obtenção do grau de mestre em Filosofia.

Orientador: Prof. Rodrigo Guimarães Nunes

Rio de Janeiro

Agosto de 2017 


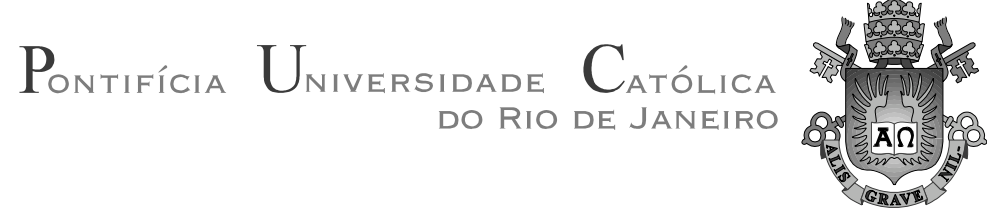

Maikel da Silveira

\title{
O grito populista: \\ populismo e afeto no capitalismo tardio
}

Dissertação apresentada como requisito parcial para obtenção do grau de Mestre pelo Programa de PósGraduação em Filosofia do Departamento de Filosofia do Centro de Teologia e Ciências Humanas da PUC-Rio. Aprovada pela Comissão Examinadora abaixo assinada.

\author{
Prof. Rodrigo Guimarães Nunes \\ Orientador \\ Departamento de Filosofia - PUC-Rio
}

Prof. Gabriel Tupinambá

Departamento de História - PUC-Rio

Prof. Pablo Ortellado

Universidade de São Paulo - USP

Profa. Monah Winograd

Coordenadora Setorial do Centro de Teologia e Ciências

Humanas - PUC-Rio

Rio de Janeiro, 23 de agosto de 2017 
Todos os direitos reservados. É proibida a reprodução total ou parcial do trabalho sem a autorização da universidade, do autor e do orientador.

\section{Maikel da Silveira}

Graduou-se em Comunicação Social, habilitação em Jornalismo, pela Faculdade J.Simões - 2004.

Ficha Catalográfica

Silveira, Maikel da

O grito populista : populismo e afeto no capitalismo tardio / Maikel da Silveira ; orientador: Rodrigo Nunes. 2017.

157 f. ; $30 \mathrm{~cm}$

Dissertação (mestrado)-Pontifícia Universidade Católica do Rio de Janeiro, Departamento de Filosofia, 2017. Inclui bibliografia

1. Filosofia - Teses. 2. Populismo. 3. Afeto. 4. Política. I. Nunes, Rodrigo. II. Pontifícia Universidade Católica do Rio de Janeiro. Departamento de Filosofia. III. Título. 


\section{Agradecimentos}

Agradeço primeiro à Thais, por dividir uma vida comigo e por acreditar em mim, apesar conviver tão de perto com minhas angústias, ansiedades e inseguranças - e por não ter me chutado quando eu ficava horas em silêncio, tentando articular conceitos com tanta desenvoltura quanto meu sobrinho de quatro anos articula peças de Lego. Por ter aceitado, com resignação, a ocupação de quase todos os cômodos do apartamento por livros - quando muito perguntando, de vez em quando, ao me ver abrir mais um pacote da Amazon: "Mas outro Espinosa?! Tá comprando repetido?".

Ao Rodrigo Nunes, claro, agradeço, em primeiro lugar, pela paciência (com a dislexia, com os zumbis \& so on \& so on) e pela generosidade. Conheci poucas pessoas na vida que dominassem tão bem um leque tão vasto de autores e conceitos e conseguisse, ao mesmo tempo, se expressar de maneira tão precisa e clara. Foi uma honra.

Ao Gabriel Tupinambá, ao Pablo Ortellado e à Tatiana Roque, agradeço por terem aceitado o convite para participar da minha banca. Meus amigos mais próximos sabem o quanto comemorei quando confirmaram presença. Esbarrei com os três nas redes sociais e devo, a cada um deles, muitos insights que desenvolvi aqui.

Agradeço aos meus pais, que nunca entenderam o que li, nunca leram o que escrevi, mas sempre me estimularam e, dentro das possibilidades, me ajudaram continuar fazendo uma coisa e outra.

Ao Orlando, agradeço por ter me apontado o caminho das pedras (filosofais). Eu não teria percorrido nem metade desse caminho sem a inspiração dele. Agradeço também a Layla, Miriam e Werley, amigos pra toda vida, que viram como tudo isso começou - e merecem saber a quantas anda.

À Deborah, agradeço pelas melhores aulas sobre Leibniz que tive na vida, por ter me deixado falar de distopias.

Se não fosse pela Alyne, acho que esse mestrado nunca teria acontecido. Não sei se ela faz ideia do quanto foi bom ter topado com ela nessa vida. (Planet Earth is blue com você. Amor sem escalas). Sem a amizade do Rafael, meu 
bibliófilo favorito, talvez eu tivesse escrito uma dissertação menos caótica, mas, na certa, estaria mais infeliz. Numa palavra: show.

Pedro, o Perspicaz, Ádamo, o Lord, PH, o Mao, boa parte do que aprendi foi bebendo naquela padaria com vocês. Ronaldo, obrigado pelas festas. Carla, obrigado por me levar pro Timoneiros. Carlos, obrigado por ter se juntado a nós. Raquel, obrigado pela força (que ela esteja com você). Mirian, obrigado por ouvir minhas teses sobre a Anitta. Obrigado, Irene, pela elegância. Gall, obrigado pela companhia de boteco, pelas piadas (era tudo piada, né?). Uriel, obrigado por tirar minhas dúvidas sobre Lacan.

Obrigado, Gabriel, por ser o melhor amigo pra se dividir uma baia, uma mesa de bar, um prato no Cosmopolita - ou pra falar da vida, do universo e de tudo mais. Ravicz, obrigado por aquela conversa no Al-Kuwait - não, mentira, obrigado por todas as longas conversas que tivemos nesses anos todos! A vida é bem mais legal com você por perto. Waltinho, Fafá, obrigado por me ouvirem falar de filosofia em nossos almoços e jantares. E por terem se tornado tão importantes pra mim e pra Thais. Erico, Amanda, Vinicius, Clarissa, Eric, Ana Maria, Douglas, Libera, obrigado pelo(s) Reveillon(s) - e por terem feito do Rio um lugar muito mais acolhedor. (E me desculpem se andei sumido). Paulo, obrigado pelos textões.

À Helena, agradeço por ter me adotado, no Rio. E por me ajudar a ser mais paciente. E pelo Maracanã. E por ser quem é. Ao Rafael Oliveira, agradeço pelas horas abonadas e pela compreensão.

À Tatiana, agradeço porque me deu um sobrinho, e vai me dar uma sobrinha (além de ser uma pessoa adorável e muito prestativa). À Carol, por ter tornado o meu período de licença mais divertido e por ter se aproximado tanto nos últimos meses.

Agradeço, enfim, a todo mundo que conviveu comigo nesses dois anos e meio. Todo mundo que sabe o quanto foi importante pra mim voltar pra universidade. O quanto isso me ajudou a segurar a onda, quando tudo parecia perdido - ou me sentir perdido, quando nada mais dava onda. 


\section{Resumo}

Silveira, Maikel da; Nunes. Rodrigo Guimarães (Orientador). O grito populista: populismo e afeto no capitalismo tardio. Rio de Janeiro, 2017, 157p. Dissertação de mestrado - do Departamento de Filosofia do Centro de Teologia e Ciências Humanas, Pontifícia Universidade Católica do Rio de Janeiro.

A proposta desta dissertação é abordar o potencial do populismo na organização política ou, mais precisamente, na constituição de corpos eficazes. O trabalho apresenta os principais conceitos mobilizados pela teoria do populismo, de Ernesto Laclau e, num diálogo com autores como Yannis Stavrakakis, John Protevi, Vittorio Morfino, Frédéric Lordon e Espinosa, tem como objetivo aprofundar a discussão acerca dos aspectos afetivos envolvidos na construção do discurso populista, bem como investigar a possível relação entre a recente explosão populista, sobretudo nos Estados Unidos e na Europa, e determinadas características do chamado capitalismo tardio.

\section{Palavras-chave}

Populismo; afeto; política. 


\section{Abstract}

Silveira, Maikel da; Nunes. Rodrigo Guimarães (Advisor). The populist scream: populism and affect in late capitalism. Rio de Janeiro, 2017, 157p. Dissertação de mestrado - do Departamento de Filosofia do Centro de Teologia e Ciências Humanas, Pontifícia Universidade Católica do Rio de Janeiro.

The purpose of this dissertation is to address the potential of populism in political organization or, more precisely, in the constitution of effective bodies. The paper presents the main concepts mobilized by Ernesto Laclau 's theory of populism and, in a dialogue with authors such as Yannis Stavrakakis, John Protevi, Vittorio Morfino, Frédéric Lordon and Espinosa, aims to deepen the discussion about the affective aspects involved in the construction of a populist discourse, as well as investigating the possible relationship between the recent populist explosion, especially in the United States and Europe, and certain characteristics of so-called late capitalism.

\section{Keywords:}

Populism; affect; politics 


\section{Sumário}

1. Introdução 10

2. Democracia, hegemonia, discurso e alguns espectros 14

2.1. O paradoxo democrático e seus espectros 15

2.2. Hegemonia 18

2.3. O populismo como lógica do político 27

2.4. Nomeação, investimento radical, catexia: o papel do afeto na constituição das identidades populares $\quad 32$

2.5. Lacan e as aventuras do afeto 39

3. Crise ou mudança estrutural? Capitalismo democrático, razão neoliberal e desdemocratização 53

3.1. Crise do capitalismo democrático?

3.2. Biopolítica e razão neoliberal 63

3.3. Neoliberalismo e desdemocratização 68

3.4. A nova armadura institucional do capitalismo e a $\begin{array}{ll}\text { desdemocratização } & 77\end{array}$

3.5. A razão neoliberal e a desdemocratização 84

3.6. O ocaso neoliberal: mudança estrutural e causalidade imanente 93

4. Afeto e relacionismo radical em Espinosa 100

4.1. O relacionismo radical e o atravessamento das paixões 100

4.2. Os afetos primários 106

4.3. Da multidão ao corpo político 112

4.4. A razão populista e a coalizão de forças desejantes 120

4.5. A gênese de um ingenium 128

4.6. Expressões da indignação na explosão populista 135

5. Conclusão: Das ruínas às estradas (ou um pitaco sobre geringonças, manipulação do oikos e espaços de "descapitalização")

6. Referências bibliográficas 


\section{Lista de abreviações}

Todos os autores citados nesta dissertação estão referenciados de acordo com as regras da $\mathrm{ABNT}$, com exceção de Espinosa, cujas obras consultadas constam na bibliografia, mas as citações e referencias no corpo do texto obedecem às seguintes abreviaturas, que virão acompanhadas do número da página na edição consultada.

E

Ap

Ax

$\mathrm{C}$

$\mathrm{D}$

Daf

DGA

Dem

Lem

$\mathrm{P}$

Pos

Pref

Esc

$\mathrm{TP}$

TPT

TCI

Carta (No)

BT

PM
Ética: demonstrada à maneira dos geômetras

Apêndice

Axioma

Corolário

Definição

Definição dos Afetos

Definição Geral dos Afetos

Demonstração

Lema

Proposição

Postulado

Prefácio

Escólio

Tratado Político

Tratado Político-Teológico

Tratado da Correção do Intelecto

Correspondência Completa

Breve Tratado

Pensamentos Metafísicos 


\section{Introdução}

"Before I speak, I have something

important to say".

Groucho Marx

A proposta deste trabalho é apresentar os principais aspectos da teoria do populismo de Ernesto Laclau e buscar compreender em que medida isso que ele entende como uma "lógica do político" pode funcionar como uma ferramenta teórica útil para a organização política, mais precisamente, para a construção de corpos políticos eficazes. Essa reflexão foi, em grande medida, inspirada pela proliferação de uma série de manifestações recentes de populismo, sobretudo nos Estados Unidos e na Europa, o que John B. Judis (2016) chamou de "explosão populista”. É sobre essa explosão populista, que se pretende lançar alguma luz aqui, a partir das teses de Laclau, e sobre o pano de fundo do que pode ser compreendido como uma mudança da armadura institucional do capitalismo (Lordon, 2015), que se confunde com o fim do que se pode chamar de era de ouro do capitalismo democrático nas economias centrais, dos Estados Unidos e da Europa, o período de trinta anos que sucedeu o pós-guerra, o ápice do chamado fordismo e o grande momento do estado de bem-estar social (Streeck, 2012). Se, no pós-guerra, capitalismo e democracia viveram, nas economias centrais, uma duradoura lua de mel, pode-se dizer que, na virada para os anos 1970, o casamento entrou em crise. Fatores como a crise do petróleo, a desaceleração das economias, a queda nas taxas de lucro das empresas e o crescimento da inflação, tudo isso contribuiu para abalar as estruturas desse relacionamento, abrindo passagem para a ascensão do pensamento coletivo neoliberal - o neoliberalismo abordado como como uma racionalidade, tal como foi pensado por Michel Foucault (2008), em seus cursos sobre O Nascimento da Biopolítica. Às teses de Foucault, somam-se as de Wendy Brown, que, recentemente, retomou e levou mais longe alguns insights do pensador francês para pensar a relação entre o neoliberalismo e o que ela vem chamando de "desdemocratização" das democracias. Desdemocratização que, para ela, emerge como uma consequência 
da submissão não só das instituições democráticas, mas também de toda esfera pública e privada aos critérios, controles e métricas da economia. O que se quer, com essa abordagem, é pensar como fica o populismo, compreendido como lógica do político num contexto onde o político, amarrado institucional e subjetivamente pela razão neoliberal, tem cada vez menos espaço nas "democracias".

Para Ernesto Laclau, a questão dos afetos é fundamental para determinar o sucesso ou o fracasso de um "corte populista". A forma como o autor aborda essa dimensão dos afetos, a partir do referencial psicanalítico, será retratada no capítulo dedicado à apresentação dos principais conceitos articulados pelo filósofo argentino. Na última parte do texto, o tema do afeto será retomado de uma outra perspectiva, a partir de algumas leituras contemporâneas de Espinosa. A intenção é desvencilhar-se um pouco do referencial psicanalítico, com sua ênfase excessiva na questão do indivíduo, para abordar os afetos de uma perspectiva transindividual (Morfino, 2014; Lordon, 2015). O objetivo dessa escolha teórica nasce da impressão que a teoria laclauniana do populismo dá pouca atenção à importância das "estruturas globais" que incidem sobre nossos corpos e produzem, de uma perspectiva espinosista, afetos de toda ordem. O que se quer com isso é compreender como funciona o populismo no interior dessa estrutura global do Capitalismo Mundial Integrado - CMI (Guattari e Rolnik 1986). Por fim, procura-se demonstrar de que modo uma compreensão adequada - ou tão adequada quanto possível - de como essas estruturas incidem sobre é algo fundamental para aumentar a eficácia de um corte populista, não só em sua tentativa produzir hegemonia, mas em sua capacidade de transformar, efetivamente, determinadas configurações do social. Sem atentar para esses aspectos todos, é grande a chance de que o que se acredita ser um "corte" não passe de um "grito": uma expressão do desespero diante do horror da servidão humana - ou da força dos afetos.

$\mathrm{Na}$ conclusão, que tem um tom mais ensaístico, procura-se amarrar todas essas questões e explicar de que modo uma série de afetos, produzidos por estruturas globais, levaram à escolha do populismo como objeto de pesquisa desta dissertação.

Embora a explosão populista funcione aqui como um norte, não há interesse em levar adiante nenhum estudo de caso sobre as recentes manifestações do populismo. Eventos recentes serão evocados, obviamente, a fim de ilustrar de que 
modo os conceitos que serão discutidos ao longo do trabalho podem ser mais ou menos percebidos neles. O contexto contemporâneo operou, por assim dizer, em segundo plano, ao longo da pesquisa - ora reforçando certas linhas de investigação, ora levantando dúvidas.

Essa dissertação articula, por vezes, autores cuja compatibilidade, reconheço, é discutível. Procurei me esquivar, na medida do possível, de aproximar demais, por exemplo, a psicanálise lacaniana da esquizoanálise. Não porque não ache que essa compatibilidade exista, mas porque defender isso de maneira consistente exigiria um esforço teórico que, evidentemente, não daria pra fazer aqui - e, sinceramente, não me vejo sequer em condições de fazê-lo (hoje).

Espero não ter sido demasiadamente herético nas "bricolagens". Procurei me servir aqui da filosofia (mas não só) como "caixa de ferramentas", como diria Foucault, para tentar responder a uma série de questões que, acredito, não afetam a mim apenas, mas grande parte do mundo contemporâneo hoje. Sei que ora peco pelo excesso, me detenho excessivamente sobre um autor ou conceito e me torno repetitivo; ora passo rápido demais por um número demasiado grande de filósofos, em transições às vezes abruptas. Se grande parte disso posso atribuir ao ingenium, outra parte posso atribuir à febre que tomou conta de mim quando decidi fazer mestrado em filosofia tendo vindo, originalmente, da área de Comunicação - e depois de 10 anos longe da faculdade. Passei pelo que meu orientador chamou, à época da qualificação, de "problema da loja de doces". Um desespero por recuperar o máximo de tempo perdido, conhecendo o máximo de autores e absorvendo o maior número de conceitos.

Não me refiro a esse contexto em busca de condescendência (embora reconheça que essas negações sempre tenham algo de suspeitas). Tem mais a ver, creio, com coerência mesmo. Afinal, um dos aspectos centrais da minha argumentação, ao longo do texto, tem a ver justamente com a importância de reconhecer a força dos afetos, das estruturas que nos constituem, mas, apesar delas, avançar, a despeito das contradições. Seria pouco espinosista de minha parte lamentar o que poderia ter feito. Como sugere François Zourabichvili (2014), não há espaço para futuro do pretérito no espinosismo. Como diria 
Borges: "falar é incorrer em tautologias". Tautologicamente, falo, portanto: fiz o que está feito. Agora, seja o que Deus - ou a Natureza - quiser. 


\title{
2 \\ Democracia, hegemonia, discurso e alguns espectros
}

\author{
"As ficções servem para descobrir \\ coisas, e mudam conforme mudam as \\ necessidades de fazer sentido. Os mitos \\ são os agentes da estabilidade. As \\ ficções, os agentes da mudança" \\ Frank Kermode
}

A proposta deste capítulo é apresentar os principais aspectos da teoria do populismo de Ernesto Laclau. Para isso, é imprescindível elucidar uma série de conceitos agenciados pelo autor para a construção dessa teoria. Serão apresentados não apenas o conceito de hegemonia e discurso, que constituem o fundamento ontológico desta teoria, mas também outros conceitos com os quais estes relacionam, por exemplo, o conceito de democracia, que, na teoria do populismo, possui um caráter que pode ser descrito como espectral (Derrida, 1994).

Como o próprio Laclau (2013) reconhece, os fundamentos teóricos do conceito de populismo que ele põe em cena são bastante ecléticos. Vão da linguística de Saussure, passando pelo pós-estruturalismo e pelo segundo Wittgenstein, sem deixar de recorrer à psicanálise, com Freud e Lacan, nem tampouco abandonar o diálogo com o marxismo, principalmente a partir de figuras como Gramsci e Rosa Luxemburgo. Todo esse referencial, deve-se dizer, está a serviço da crítica do marxismo e visa restabelecer o primado do político sobre o econômico no entender do autor (e de sua parceira de vida e obra, Chantal Mouffe). O pós-marxismo de Laclau e Mouffe, pode-se dizer, tem contornos "pós-modernos" e ecoa, em grande medida, o movimento de crítica das metanarrativas. Todo esse contexto está refletido, mais ou menos explicitamente, na teoria da hegemonia, que resulta numa defesa apaixonada do caráter contingente de toda formação social e do protagonismo das identidades políticas na configuração desse espaço. A teoria do discurso é, para os autores, uma ferramenta fundamental para compreender o processo de constituição dessas 
identidades. Por discurso, os autores entendem não apenas a linguagem falada ou escrita, mas uma totalidade que inclui, igualmente, conteúdos extralinguísticos. Pode-se dizer que eles não fazem distinção entre atos, falas e atos de fala. Tudo opera num mesmo campo e são fundamentais em qualquer processo de significação.

É sobre esse pano de fundo (apresentado nos subcapítulos 2.1 e 2.2) que a lógica populista será descrita por Ernesto Laclau como a própria lógica do político. O modo de funcionamento dessa lógica, conforme compreendido por Laclau, será objeto do subcapítulo 2.3. Nele, explica-se a dinâmica entre equivalência e diferença que está em jogo no corte populista, bem como a categoria de demanda e a importância atribuída por Laclau à construção de cadeias de equivalência entre demandas heterogêneas, por meio de significantes vazios ou flutuantes, como forma de produzir identidades políticas.

Por fim, no subcapítulo 2.4, entra-se na questão afetiva, que Laclau aborda sobretudo a partir do referencial oriundo da psicanálise lacaniana. Com o recurso de outro autor, Yannis Stavrakakis, procura-se mostrar o percurso que leva do afeto à jouissance na teoria lacaniana. Ao mesmo tempo, discute-se a crítica de Stavrakakis ao conceito laclauniano de discurso em nome da importância de uma abordagem distinta da questão do afeto, elemento fundamental na constituição de identidades políticas.

\section{1 O paradoxo democrático e seus espectros}

A democracia moderna pode ser compreendida a partir de seu caráter espectral (Derrida, 1994). Disso resulta, em grande medida, a dificuldade que não raro encontramos para defini-la. Desde sua origem grega, ela está associada ao ideal de soberania popular - o ideal de um demos soberano. É em nome dessa soberania que o povo pressiona as instituições democráticas e seus representantes para exigir mudanças no sistema, a fim de ter seus interesses representados. Essa soberania, no entanto, existe apenas como um horizonte inalcançável que, ao mesmo tempo, promove mudanças efetivas, na medida em que sua existência nos mantém, por assim dizer, em constante movimento, e, por outro lado, desloca-se à medida que dela nos aproximamos. Nisso consiste o caráter espectral da 
democracia, teorizado por Derrida, para quem ela é sempre uma democracia por vir (Derrida, 1994).

Mas o que se pretende mudar com a pressão popular? Dito de modo simples: o sistema. As leis, instituições e organizações que determinam os limites dentro dos quais a soberania se exerce (ou não). Para Chantal Mouffe (2000), nas democracias modernas, esses limites são estabelecidos pelos princípios liberais de liberdade individual e direitos humanos universais, "valores centrais para a tradição liberal, constitutivos da visão de mundo moderna" (Mouffe, 2000, p.2), mas que não estão na origem da tradição democrática. $\mathrm{O}$ ideal da soberania popular entra sempre numa espécie de conflito com esses princípios liberais, o que confere à democracia moderna seu caráter paradoxal e, no entender de Mouffe, agonístico.

O paradoxo democrático é, para a autora, o específico da democracia moderna, aquilo que a diferencia da democracia clássica. Não se trata, simplesmente, de uma mudança de tamanho - a democracia moderna não é uma democracia que inclui mais pessoas, uma simples ampliação do demos e dos limites da polis - mas de uma mudança de natureza, expresso nesse equilíbrio instável de duas lógicas conflitantes. Para Mouffe, é importante lutar pela manutenção desse arranjo, que confere às democracias modernas seu caráter pluralista, relacionado com "o fim de uma ideia substantiva de boa vida, o que Claude Leffort chamou de 'dissolução dos marcadores de certeza'" (Mouffe, 2000, p.14). Segundo a autora, é importante que nenhum dos lados prevaleça. Uma democracia orientada unicamente pelo princípio da soberania popular poderia resultar, por exemplo, numa tirania da maioria. Por outro lado, uma sociedade orientada unicamente pelo ideal de liberdade individual e direitos humanos universais poderia tornar-se igualmente opressiva, esmagando particularidades culturais e modos de vida incompatíveis com o modelo liberal. Para Mouffe, é a oscilação entre estes extremos que produz mudanças na estrutura democrática. $\mathrm{O}$ povo pressiona as instituições para fazer valer o princípio da soberania, de um lado; as instuições limitam o povo, para tentar garantir a liberdade individual e os direitos humanos, de outro.

Como a questão do populismo, que emerge do interior desse corpo democrático paradoxal, se insere nessa discussão? Uma das hipóteses que está em jogo aqui é a de que o populismo depende, para ser posto em ação, tanto dessa 
ideia de soberania do demos quanto de outros espectros, como as ideias de liberdade, igualdade e justiça, que, na teoria do populismo (Laclau, 2011; 2013), podem operar, quando encarnadas numa liderança, num movimento ou num partido, como significantes vazios ou flutuantes, que servem para representar uma ausência, uma falta, uma carência no interior do corpo democrático; a falta constitutiva em torno da qual se podem construir hegemonias. Esclarecer melhor a relação entre os conceitos de espectro, deslocamento, significante vazio ou flutuante e hegemonia é um passo crucial para uma abordagem adequada da teoria do populismo.

Para Derrida, o espectro é "uma incorporação paradoxal, o tornar-corpo, uma certa forma fenomênica e carnal do espírito" (Derrida apud Laclau, 2011, p.110). Nem carne, nem espírito, mas igualmente um e outro ao mesmo tempo, pois

[S]ão a carne e a fenomenalidade que dão ao espírito sua aparição espectral, mas os quais desaparecem imediatamente na aparição, no vir mesmo do revenant ou no retorno do espectro, há alguma coisa desaparecida, ausente na aparição mesma como reaparição do ausente. (Derrida apud Laclau, 2011, p.110)

O espectro, enquanto manifestação do espírito, não tem corpo, no entanto, corporifica-se: apresenta-se com o corpo do morto, com as características, os traços, a aparência de um corpo que já não é. Um corpo desaparecido, ausente, um corpo que é passado: o espectro manifesta-se, desse modo, como presença dessa ausência. Como aponta Laclau, "o anacronismo é essencial para a espectralidade" (Laclau, 2011, p.110), tanto quanto a indecidibilidade entre carne e espírito. Derrida elabora esse problema da seguinte forma: "Para haver fantasma, tem que haver um retorno ao corpo, mas para um corpo mais abstrato do que nunca" (Derrida apud Laclau, 2011, p.110). Uma vez que o espírito precisa produzir visibilidade a partir de sua invisibilidade, torna-se extremamente difícil distinguir o espírito do espectro (Laclau, 2011).

Para Derrida, Marx, em sua teorização do fetichismo da mercadoria, gira em torno da "rondologia"1 (hantologie), pois não apenas o valor de troca, mas

\footnotetext{
${ }^{1}$ A expressão "hantologie" é normalmente traduzida para o inglês como hauntology e, para o português como "espectrologia". Rondologia é uma tradução feita pelo próprio Laclau para a edição espanhola de Emancipation(s). Em nota explicativa, ele argumenta que o termo Hanter, em francês, significa cernir, rondar como um fantasma. Laclau acredita que, nesse sentido, "rondologia" seria a tradução adequada. Essa justificativa está reproduzida numa
} 
também o valor de uso dos produtos, no capitalismo, encontra-se marcado pela lógica do espectro, pois "não há valor de uso no qual a possibilidade de troca e de comércio (...) não tenha inscrito de antemão um fora de uso - uma significação excessiva que não possa ser reduzida ao sem-uso" (Derrida apud Laclau, 2011, p.111). A rondologia teria, para ele, uma centralidade na produção dos vínculos sociais.

Marx, no entanto, tentou a crítica do rondológico, a partir da perspectiva de uma ontologia. Se o espectro habita a raiz do vínculo social na sociedade burguesa, a transcendência da última, a chegada a um tempo que não está mais deslocado, a realização de uma sociedade plenamente reconciliada com ela mesma abrirá o caminho para "o fim da ideologia" - ou seja, para uma sociedade puramente ontológica, que, após a consumação do milênio proletário, verá a rondologia como seu passado. Tendo em vista que a rondologia é inerente à política, a transcendência da divisão entre ser e aparência significará o fim da política (poderíamos, de fato, pôr esse argumento em termos saint-simonianos: a transição do governo dos homens para a administração das coisas). (Laclau, 2011, p.112)

Para Laclau, há um espectro de Marx - o fantasma do comunismo - que ronda a sociedade burguesa, como aponta Derrida, mas também um espectro que ronda o próprio Marx: o fantasma de uma sociedade plenamente reconciliada, que visita sua obra e impede de estabelecer uma "ontologia não assombrada" (Laclau, 2011, p.113). Assim, conclui Laclau, "o lugar a que chegamos - o de um presente nunca idêntico consigo mesmo - é o próprio terreno dessa prática fantasmática, sem essência, que denomino política (Laclau, 2011, p.113).

\section{2 Hegemonia}

Laclau e Mouffe rejeitam a ideia de uma socieadde plenamente reconciliada. Esse é um elemento fundamental da teoria da hegemonia. "A impossibilidade da sociedade" é um conceito desenvolvido por Laclau em artigo homônimo (Laclau, 1990), no qual o autor opõe a compreensão da ideologia tanto como totalidade inteligível do social quanto como falsa consciência, concepções que pressupõem, respectivamente, a crença na possibilidade de uma representação da totalidade do social e um fundamento a ser revelado/denunciado pela crítica. Para Laclau, como já foi pontuado anteriormente aqui, essa representação é impossível (e 
nisso, possivelmente, ele concorda com a crítica das metanarrativas, feita pelos teóricos da chamada pós-modernidade): não existe um fundamento último para o social. Laclau critica a aspiração de cunho essencialista a uma representação totalizante da realidade social que, para ele, deve ser aceita em sua infinitude, uma vez que:

todo sistema estrutural é limitado, (...) está sempre envolto por um "excesso de sentidos" que somos incapazes de dominar e que, consequentemente, a "sociedade" como um objeto unitário e inteligível que embasa seu próprio processo parcial é uma impossibilidade. (Laclau, 1990, p.90)

Tomando como base o caráter diferencial de toda identidade num dado sistema, segundo a perspectiva estruturalista, Laclau acredita que devemos recusar toda tentativa de fixá-la definitivamente e o social deve ser associado, por sua vez, ao "infinito jogo das diferenças" que constitui, na teoria laclauniana, o discurso. Para o autor, um discurso condenado ao infinito jogo das diferenças, incapaz de fixar qualquer tipo de significado, assemelha-se ao discurso de um psicótico. Algum tipo de fixação tem que ser possível.

É nesse ponto que incide o conceito de hegemonia:

O social não é apenas o infinito jogo das diferenças. É também a tentativa de limitar esse jogo, de domesticar a infinitude, de abarcá-la numa ordem finita. Mas essa ordem - ou estrutura - não mais toma a forma de uma essência subjacente do social; em vez disso, é uma tentativa - por definição instável e precária - de agir sobre o "social" para hegemonizá-lo. (Laclau, 1990, p.91)

Para Laclau e Mouffe, a hegemonia é o resultado de uma prática articulatória que produz um discurso capaz de funcionar como ponto de convergência de sentido para possibilidades significativas heterogêneas, que carecem de localização diferencial da ordem simbólica e excedem-na. A hegemonia agrega em seu interior uma série de pontos de vistas, demandas e atitudes que, sem ela, não teriam nenhuma relação necessária entre si. A condição para que a hegemonia se estabeleça "é que uma força social particular assuma a representação de uma totalidade que lhe é radicalmente incomensurável" (Laclau e Mouffe, 2015, p.37). Para os autores, essa é a única totalidade que está ao alcance de uma comunidade política. O fundamento ontológico dessa teoria encontra-se no conceito de discurso que os autores põe em cena. 
O conceito de discurso, para Laclau e Mouffe, não se resume à linguagem falada ou escrita, mas abrange todo e qualquer ato significativo. Trata-se, por assim dizer, de um conceito expandido de discurso que diz respeito a "totalidades discursivas" que incluem tanto elementos linguísticos quanto extralinguísticos. Uma resposta a uma crítica de Norman Geras a Hegemonia e Estratégia Socialista, os autores explicam, de maneira bastante didática, sua concepção. Começam tomando como exemplo o processo de construção de um muro. $\mathrm{O}$ contexto envolve dois trabalhadores. Um deles, no alto da escada, pede ao colega que lhe alcance um tijolo. O colega atende a solicitação e passa o tijolo, que é imediatamente acrescentado ao muro em construção pelo outro pedreiro. Se quiséssemos separar os componentes linguísticos e extralinguísticos dessa interação, o primeiro gesto, o de pedir um tijolo, seria um gesto linguístico; o segundo, colocar o tijolo sobre o muro, seria extralinguístico. Essa, no entanto, é uma descrição que pouco tem a dizer sobre o que está ocorrendo, sobre o contexto no qual os dois atores estão envolvidos: o da construção de um muro. No diálogo entre os dois trabalhadores, o linguístico só faz sentido em relação a esse contexto extralinguístico. As duas dimensões são absolutamente indissociáveis. O que vale para o tijolo, vale para todos os objetos com os quais nos relacionamos no mundo. Seu significado depende de um conjunto de relações, de uma totalidade que Laclau e Mouffe chamam de discursiva. Outro exemplo: "Se chuto um objeto esférico na rua ou uma bola num jogo do futebol, o efeito físico é o mesmo, mas seu significado é diferente" (Laclau, 1990, p.100). O “objeto esférico" só se torna bola em determinado contexto, quando sua presença é interpretada e ela é reconhecida dentro de um determinado sistema de relações . É a existência do jogo de futebol - uma criação humana - que permite que o objeto esférico seja identificado com uma bola de futebol. Ao afirmarem que tudo é discurso, Laclau e Mouffe estão longe de incorrer num idealismo solipsista, que nega a existência concreta das coisas. Os autores argumentam que uma série de ações, como as que estão implicadas no processo de construção de um muro, poderiam ser descritas em unidades mínimas, como acontece na psicologia comportamental (behaviorista), que tivessem como ponto de partida os objetos em sua mera existência, por exemplo: "X emite uma série de sons; Y dá um objeto cúbico a $\mathrm{X} ; \mathrm{X}$ adiciona o objeto cúbico a um conjunto de objetos cúbicos similares, etc." (Laclau, 1990, p.101). Eles deixam cargo do leitor a tarefa de 
escolher qual a melhor maneira de descrever a construção de um muro. Outra questão levantada pela noção de discurso defendida por Laclau e Mouffe diz respeito à necessidade de distinguir o sentido da ação. Mesmo que admita que o sentido de uma ação é indissociável dela, não teria a ação em si mesma algo de outra ordem? Os autores argumentam que, do ponto de vista do sentido, se aplica a distinção clássica entre semântica - que lida com o sentido das palavras - e pragmática - que lida com a maneira como essa palavra é utilizada em determinado contexto. Para Wittgenstein, pontuam, o significado e o uso de uma palavra estão intimamente ligados. O significado é apreendido e moldado no e pelo uso, tanto sua apreensão quanto sua configuração depende da pragmática que, por sua vez, dá origem aos jogos de linguagem.

O uso de um termo é um ato - nesse sentido faz parte da pragmática; por outro lado, o significado só é constituído nos contextos atuais de uso do termo: nesse caso, a semântica é inteiramente dependente dessa pragmática, da qual pode ser separada - quando muito - apenas analiticamente. Isso quer dizer, em nossa terminologia, que toda identidade ou objeto discursivo é constituído no contexto de uma ação" (Laclau, 1990, p.102).

Para Laclau e Mouffe fatos naturais (da física, da biologia, da astronomia) são também fatos discursivos. "E eles são assim pela simples razão de que a ideia de natureza não é algo dado, a ser lido na aparência das coisas, mas é resultado de uma complexa construção histórica e social" (Laclau, 1990, p.102). Em outras palavras, só podemos classificar algo como objeto natural, porque dispomos de um sistema de classificação. Dizer isso não significa negar, por exemplo, a existência de uma rocha. Mas dizer que não é a mera existência dessa pedra que faz dela uma matéria prima ou um objeto de culto, tampouco ajuda a distinguir uma pedra da outra.

A genealogia do conceito remete tanto à filosofia analítica, quanto à fenomenologia e ao estruturalismo. Nos três casos, argumentam os autores, a tentativa inicial de obter um acesso imediato às coisas mesmas - um acesso não mediado pela linguagem - fracassou e dissolveu-se em algum momento: na filosofia analítica, com o segundo Wittgenstein, na fenomenologia com a analítica existencial de Heidegger, e no estruturalismo com a crítica pós-estruturalista. O mesmo movimento os autores identificam na epistemologia, com a transição que 
vai do verificacionismo a Paul Feyerabend, passando por Karl Popper e Thomas Kuhn; bem como no marxismo, que com Gramsci teria visto diluírem-se as identidades de classe do marxismo clássico, ora preteridas em nome de "identidades hegemônicas construídas através de mediações não-dialéticas" (Laclau e Mouffe, 2015, p.38).

De todas essas correntes teóricas, o pós-estruturalismo foi a que mais influenciou os autores na construção de sua teoria da hegemonia, especialmente por meio das obras de Derrida e Lacan. Da desconstrução, Laclau e Moufe trouxeram a noção de indecidibilidade, que permite identificar no campo outrora definido como estrutural um sem número de indecidíveis. Para os autores, podese, inclusive, "ver a hegemonia como uma teoria da decisão tomada num terreno indecidível” (Laclau e Mouffe, 2015, p.38).

Níveis mais profundos de contingência requerem articulações hegemônicas - isto é, contingentes - o que é outra maneira de dizer que o momento de reativação não significa outra coisa que não a recuperação de um ato de instituição política, que encontra em si mesmo sua única fonte e motivação. (Laclau e Mouffe, 2015, p.38)

Da psicanálise lacaniana, os autores trouxeram as categoria de point de capiton, que denoninaram, por sua vez, ponto nodal. O conceito de ponto nodal denota um elemento particular capaz de assumir o papel de estruturante "universal" no interior de um determinado campo discursivo. Quando isso ocorre, o ponto nodal funciona como um significante vazio (o equivalente, na teoria do populismo, ao significante-mestre na psicanálise lacaniana). Toda organização que esse campo discursivo venha a assumir emergirá, para os autores, apenas como resultado dessa função de ponto nodal exercida por um elemento particular desse conjunto discursivo e isso não dependerá da particularidade desse elemento per $s e^{2}$. Para os autores, representações hegemônicas criam retrospectivamente os interesses que representam. A hegemonia exige, no entanto, condições de possibilidade muito precisas.

Se a objetividade social, através de suas leis internas, determinasse qualquer que fossem os arranjos estruturais (como uma concepção puramente sociologizante da

\footnotetext{
${ }^{2}$ Se, por exemplo, um partido assume esse papel de ponto nodal, como no caso do Solidariedade, o sindicato polonês que ocupou a centralidade da luta contra o regime soviético naquele país, suas características particulares importam menos que o papel organizador que ele desempenha no espaço sócio-político (ou campo discursivo).
} 
sociedade) não haveria espaço para rearticulações hegemônicas - nem, na verdade, para a política como atividade autônoma. (Laclau e Mouffe, 2015, p.39).

Ou, como coloca Laclau em outro texto (1994), se os agentes tivessem lugares pré-definidos para ocupar na estrutura social, a emergência das identidades seria impossível: tratar-se-ia apenas de descobri-las ou reconhecê-las. É na inexistência de papéis e lugares predeterminados para os atores políticos, que reside o problema do deslocamento, que dá origem à impressão de que as coisas encontram-se fora do lugar ou propicia a experiência de um "tempo fora do eixo" - o "time out of joint" anunciado por Hamlet, no trecho que inspirou o conceito de espectro desenvolvido por Derrida. O deslocamento, sob a ótica da hegemonia, no entanto, não tem a ver literalmente com coisas fora de lugar, porque tais lugares não existem a priori, mas com uma falta constitutiva que desafia as identidades (Laclau, 1994).

O conceito de identidade, que está em jogo na teoria da hegemonia, remete à psicanálise lacaniana e à ideia de que há uma falta na raiz de toda identidade: é preciso se identificar com alguma coisa, porque há, em tudo, uma falta originária e insuperável de identidade (Laclau, 1994). Essa falta como limite não deve ser compreendida num sentido puramente negativo, proibitivo ou castrador. Como aponta Stavrakakis (2007), Laclau e Mouffe enxergam corretamente nessa falta uma dimensão produtiva. É ela que possibilita aos seres humanos (re)construírem continuamente as identidades políticas e sociais.

É possível dizer que o clima de "pós-verdade" que toma conta do espaço político contemporâneo, por meio do qual todo fato torna-se mera interpretação, é um terreno fértil para as articulações hegemônicas e para a proliferação de identidades políticas. Períodos de crise institucional, quando a solidez das instituições passa a ser questionada, atendem igualmente ao mesmo critério. É nesse sentido que Laclau se referia, em trecho citado anteriormente, à política como terreno de uma prática fantasmática, sem essência. "Para que haja hegemonia, o requisito é que os elementos cuja própria natureza não os determina a fazerem parte de um arranjo ou de outro não obstante convirjam, em decorrência de uma prática externa ou articulatória” (Laclau e Mouffe, 2015, p.39). Essa prática externa ou articulatória pressupõe a visibilidade de "atos de instituição originária" (ibidem, loc. cit.) que criam sujeitos políticos contingentes. "Privilegiar o momento político na estruturação da sociedade é um aspecto 
essencial de nossa abordagem" (ibidem, loc. cit.), esclarecem os autores. Toda hegemonia tem, para eles, pretensões universais.

Trata-se, no entanto, de um universalismo que nada tem a ver com o contrato hobbesiano, com a instituição de um Leviatã, nem tampouco com a ideia marxista do proletariado como classe universal. A universalidade da hegemonia decorre de uma dialética específica entre as lógicas da equivalência e da diferença. Para Laclau e Mouffe (2012), todos os atores sociais ocupam posições diferenciais nos discursos que constituem o tecido social. São, no sentido estrito, particularidades. Esse tecido social povoado de particularidades é, no entanto, rasgado por antagonismos que criam fronteiras em seu interior. Grupos de interesse, partidos, facções, organizações que disputam a hegemonia. É possível, no entanto, que diante de ameaças representadas por determinadas forças opressoras, tais grupos deixem em segundo plano suas diferenças para estabelecer relações de equivalência entre si. Eles se unem contra um inimigo comum. Para que isso aconteça, no entanto, é preciso que a totalidade dessa cadeia possa ser representada, de alguma forma, para além dos particularismos que as diferenciam.

O que pode representar esta totalidade? Como argumentamos, somente uma particularidade cujo corpo esteja dividido, pois sem deixar de ser sua própria particularidade, ela transforma seu corpo em representação de uma universalidade que a transcende (a universalidade da cadeia de equivalências). Esta relação, por meio da qual uma particularidade assume a representação de uma universalidade que lhe é inteiramente incomensurável, é o que chamamos de uma relação hegemônica. (Laclau e Mouffe, 2015, p.40-1)

Trata-se, no entanto, de uma universalidade contaminada, nas palavras dos autores. Uma universalidade que vive uma tensão irresolúvel entre universalidade e particularidade - como o espectro, que, segundo Derrida, como já visto antes, vive essa mesma tensão irresolúvel entre espírito e corpo. Ao mesmo tempo, a totalidade alcançada por meio da relação hegemônica tem sempre um caráter contingente. Não se trata, jamais, de uma conquista definitiva. Toda operação hegemônica é, para os autores, reversível. A universalidade, pensada em termos de hegemonia, é sempre uma universalidade política, depende das fronteiras internas da sociedade e está, por isso, marcada por um antagonismo que, no entender dos autores, não se confunde nem com uma oposição real, nem com uma contradição dialética. "Nossa tese é que os antagonismos não são relações 
objetivas, mas relações que revelam os limites de toda objetividade" (Laclau e Mouffe, 2015, p.40-1).

Para os autores, a sociedade se constitui em torno desses limites. Só há política ou, em outras palavras, só há luta por um ou outro modelo de sociedade, porque há indecidibilidade, porque não há lei transcendente ou juiz onisciente, não há um Grande Outro, em termos lacanianos, que nos diga o que fazer ou para onde ir. Há, no entanto, espectros. O espectro da justiça, da igualdade, da emancipação, da soberania que podem aparecer, corporificados, num ou noutro movimento político, numa ou noutra liderança, num ou noutro partido ou, nos termos de Laclau e Mouffe, numa ou noutra particularidade que "assume a representação de uma universalidade que lhe é inteiramente incomensurável" (Laclau e Mouffe, 2015, p.40-1).

Os significantes vazios, na teoria do populismo, incorporam, portanto, a falta constitutiva. Não é nenhuma propriedade empírica que confere a esse significante sua importância, mas o fato de, ao entrar em cena, permitir ao sujeito ver um determinado estado de coisas e apreendê-lo como totalidade: sua importância reside nesse efeito de totalização que constitui, ao mesmo tempo, fechamento e abertura, na medida em que é sempre possível buscar, por trás dele, um significado mais profundo, que ele ao mesmo tempo permite e garante.

Já foi mencionada, anteriormente, a relação entre o conceito de ponto nodal, na teoria da hegemonia, e o de point de capiton, na teoria lacaniana. Agora que o conceito de significante vazio foi apresentado mais detalhadamente, é importante enfatizar que a passagem do ponto nodal ao significante vazio nem sempre ocorre. "Nem toda posição na sociedade, nem toda luta é igualmente capaz de transformar seus conteúdos próprios num ponto nodal que possa se tornar um significante vazio" (Laclau, 2011, p.76). Isso se deve, entre outras razões, ao caráter histórico das construções hegemônicas, que definem, sim, com maior ou menor força, localizações sociais desiguais para os diversos elementos do tecido social. Como aponta Laclau:

Não se trata de negar a efetividade histórica da lógica das localizações estruturais diferenciais, mas, melhor dizendo, de negar que essas localizações, como um todo, tenham o caráter de uma infraestrutura que determina, a partir de si mesma, as leis do movimento da sociedade. (Laclau, 2011, p.76). 
Segundo Yannis Stavrakakis (2007), a teoria da hegemonia, na obra de Laclau e Mouffe, pode ser caracterizada como uma ontologia negativa. Trata-se, não obstante, de uma negatividade criativa ou produtiva. Para esse autor,

[essa] aceitação de uma ontologia negativa (produtiva) é o que aproxima Laclau da problemática lacaniana em um de seus aspectos mais essenciais e reveladores. Porque na teoria lacaniana, o "discurso" de Laclau - fortemente equivalente ao simbólico de Lacan, a ordem do significante - é, de modo similar, revelado como falta: ele busca o impossível, quer dizer, a representação de uma coisa em última instância irrepresentável. Tanto no nível subjetivo quanto no objetivo, há sempre um real que escapa a nossas tentativas de dominá-lo, de representá-lo, de simbolizá-lo. É a impossibilidade de dominar esse real que divide a realidade entre subjetiva e objetiva e sustenta o desejo. (Stavrakakis, 2007, p.69)

Essa dinâmica é importante para compreendermos o papel da dimensão afetiva na passagem do ponto nodal ao significante vazio. Para Stavrakakis (2007), um discurso populista "cola" não apenas porque cristaliza uma hegemonia simbólica, mas porque "efetivamente manipula uma dimensão afetiva, libidinal" (Stavrakakis, 2007, p.21).

\begin{abstract}
A capitonnage ideológica efetuada por meio de pontos nodais semióticos tem que ser suportada por um nó no nível afetivo da jouissance para "colar". O poder simbólico e a autoridade encontram seu real suporte na dinâmica emocional da fantasia e do gozo (parcial). Da mesma forma, nenhuma mudança social ou política pode ser efetivamente instituída se é perseguida meramente no nível do conhecimento, por meio da transformação das consciências. Aqui, de novo, a dimensão do afeto e do investimento libidinal é crucial. Isso pra não falar de outros fatores (coerção, costume, dinâmicas econômicas e institucionais, o habitus, etc.) que desempenham um papel aqui. Isso apenas para asseverar a importância da muitas vezes ignorada ou rebaixada dimensão do afeto, da libido e da jouissance, que deve ser levada seriamente em conta e deve estar também profundamente implicada no funcionamento desses outros fatores. Por exemplo, pode a confiança do capitalismo tardio no consumo ser explicada em um nível puramente econômico, sem levar em conta o desejo e o gozo? E não há jouissance inconsciente e sintomática normalmente por trás da costumeira repetição social de atos e comportamentos que reproduzem estruturas de subordinação e obediência? (Ibidem, op. cit.).
\end{abstract}

Esse trecho introduz uma série de temas que serão explorados mais à frente e aponta, desde já, para alguns possíveis limites do populismo como forma de constituição de corpos políticos. Algo que tem a ver tanto com a maneira como os afetos circulam nesse corpo e contribuem para a produção de sentido, quanto com a maneira como o encontro com outros corpos influencia nessa dinâmica. Antes 
de avançar mais nesta direção, no entanto, é necessário apresentar, de maneira mais aprofundada a teoria do populismo.

\section{3 \\ O populismo como lógica do político}

Para Ernesto Laclau, o populismo é a própria lógica do político. Longe de ser uma anomalia que perturba a ordem democrática, é um gesto de ruptura que emerge em situações de "institucionalidade extrema", quando o sistema revela-se incapaz de dar conta das demandas da população. O populismo opera criando um povo, por meio de uma operação metonímica, mais precisamente, uma sinédoque na qual uma parte passa a representar o todo. Tal movimento, característico do populismo como concebido por Laclau, traduz uma operação hegemônica por meio da qual uma parte menos privilegiada, que se sente mal representada ou não representada pelo sistema - a plebs - passa a falar em nome do populus, a totalidade da população, e reivindicar sua parte num sistema do qual estariam, teoricamente, excluídos. No corte populista, a plebs se apresenta como o único representante legítimo do populus (à maneira dos sovietes, na Rússia, quando exigiam: Todo o poder aos sovietes!). A plebs, em um movimento populista, deixa de se ver apenas como parte do populus que reivindica seus direitos: a plebs passa a se identificar com a totalidade do populus e exige o reconhecimento de sua soberania para reconfigurar o espaço social à sua maneira. Para Laclau, portanto, o populismo sempre se estabelece em torno de uma dicotomia do tipo nós/eles. Para tanto, recorre, via de regra, a um léxico conhecido, cujo objetivo é instaurar esse conflito, esse antagonismo.

Como se pode depreender dos estudos de Michael Kazin (1998), o léxico mobilizado pelo discurso populista não difere muito de país para país. Quando os americanos opõem a middle class e os taxpayers do povo - aos burocrats, fat cats e Big Men da elite, o que temos é a oposição entre os "trabalhadores" e "contribuintes" do povo e os "burocratas", os "marajás" e os "peixes grandes" da elite, que se vê no discurso populista por estas bandas. O que está em jogo, nesta 
retórica, é a construção de uma oposição nós/eles, que é a própria lógica do político segundo Laclau (2013) ${ }^{3}$.

Em sua investigação sobre o populismo, Laclau toma como "unidade mínima de análise" o conceito de "demanda", palavra que, no inglês (demand), pode ser compreendida tanto como solicitação quanto como exigência; é justamente na transição de uma a outra que Laclau enxerga a possibilidade do corte populista. Às demandas diferenciais - demandas específicas ou isoladas encaminhadas aos representantes do poder público por aqueles que, por algum motivo, não se sentem representados por ele em um ou outro ponto, Laclau denomina demandas democráticas. Essa qualificação não se refere ao regime democrático, mas ao status de "sem parte", no sentido rancieriano ${ }^{4}$, dos solicitantes. O autor não questiona, tampouco, a legitimidade dessas demandas, mas permanece num plano estritamente descritivo. As únicas características que o autor retém da democracia são as seguintes: (1) essas demandas têm, implicitamente, um fundo igualitarista, e "são formuladas para o sistema por alguém que foi excluído dele (Laclau, 2013, p.191) e (2) que "sua emergência pressupõe algum tipo de exclusão ou privação" (Ibidem, loc. cit), ou, em outras palavras, um ser deficiente ${ }^{5}$. Isso remete mais uma vez, como se pode perceber, à ideia de falta constitutiva.

\footnotetext{
3 Dentro dessa lógica identificada por Kazin, John B. Judis (2016) faz uma distinção operacionalmente interessante. Para ele, o populismo de esquerda apresentaria uma estrutura binária, que oporia a base e o meio da pirâmide (o povo) ao topo (a elite ou o establishment político-financeiro). O populismo de direita, por sua vez, teria uma estrutura trinária: o povo, um recorte específico, que pode ser étnico, racial ou religioso, por exemplo, que se oporia, nesse caso, não apenas ao establishment, mas a um terceiro grupo, um estrangeiro, um forasteiro, um imigrante supostamente beneficiado pelo establishment político-financeiro. Para o autor, o populismo de esquerda difere, historicamente, dos movimentos socialistas ou social-democratas. Nele, não entra em cena a luta de classes e a abolição do capitalismo não é, para a maioria deles, uma questão importante. Difere, também, das políticas progressistas ou liberais, que visam conciliar interesses opostos de classes e grupos. O que o populismo pressupõe é um antagonismo básico entre o "povo" e a "elite", duas categorias discursivamente construídas. O populismo de direita, por outro lado, difere do conservadorismo que se identifica sobretudo com o empresariado e se posiciona contra seus críticos e adversários. Difere, também, do conservadorismo autoritário (ou fascismo), pois, a princípio, não postula a subversão da democracia mas opera, no entanto, no contexto democrático. (Judis, 2016).

${ }^{4}$ Para Jacques Rancière, o demos, nas democracias, sempre se manifesta num desentendimento, um litígio, em que aqueles que não têm lugar, que não tomam parte, cujos interesses não são representados na polis, reivindicam seus direitos, seu lugar (Rancière, 1996).

5 "Isso explica, assim espero, por que denominei essas demandas 'democráticas'. Não devido a quaisquer ligações nostálgicas com a tradição marxista, mas porque existe nessa tradição um ingrediente do conceito de 'democracia' que é vital reter: o conceito de não atendimento da demanda, que a confronta com o status quo existente e possibilita o desencadeamento da lógica de equivalências que leva ao surgimento de um 'povo'. Suponhamos que em vez de 'democráticas' as denominássemos 'específicas'. Esta última evocaria imediatamente a ideia de uma positividade
} 
As demandas democráticas são sempre encaminhadas diferencialmente, na forma de solicitações: o cidadão solicita ao poder público, na figura dos representantes - eleitos ou não -, o atendimento a uma demanda específica, concreta, por exemplo, o asfaltamento de uma rua, a construção de um posto de saúde, manutenção do sistema de iluminação pública, mais policiamento nas ruas, o aumento das linhas de ônibus ou a manutenção do preço das passagens - como no caso do Movimento Passe Livre (MPL) em junho de 2013. Os representantes podem atender ou não a essas solicitações. Uma vez atendida, a demanda deixa de existir e indica que o sistema está funcionando a contento e as demandas democráticas estão sendo atendidas. Quando isso não ocorre, no entanto, o ideal é que a negativa venha acompanhada de uma justificativa por parte dessa representação. Essa justificativa, por sua vez, pode ser aceita ou não pelo cidadão solicitante. Especialmente no segundo caso, mas não raro também no primeiro, as demandas democráticas não atendidas não desaparecem, simplesmente, mas passam a existir, negativamente, como demandas não atendidas que se acumulam, por assim dizer, à margem do sistema. São demandas para as quais o sistema não tem resposta. À medida que essas demandas se acumulam, a insatisfação da população aumenta e, aos poucos, o sentimento que o sistema não representa os interesses da população se dissemina cada vez mais. "A crise de representação se encontra na raiz de qualquer explosão populista" (Laclau, 2013, p.105) e desempenha um papel central na divisão da sociedade em dois campos: instaurase um antagonismo entre o establishment político e o "povo".

Para que esse antagonismo se manifeste, como vimos anteriormente, é preciso que essa insatisfação tome forma, que as demandas democráticas não atendidas convertam-se no que Laclau denomina demandas populares. As demandas populares não têm caráter diferencial, mas equivalencial. Nelas as solicitações se convertem em exigências. A demandas democráticas não atendidas

plena, fechada em si. Sabemos, porém, que essa positividade não existe: ou a demanda é construída diferencialmente - o que significa que sua positividade não é isolada, mas localizada num conjunto relacional - ou mantém uma relação de equivalência com outras demandas. Sabemos também que essa alternativa se justapõe àquela outra que se configura entre demandas atendidas e não atendidas. Mas uma demanda atendida deixa de ser uma demanda. É somente a falta de um atendimento, que pode oscilar entre a total rejeição e um 'estar em equilíbrio instável entre a satisfação e a não satisfação', que confere a uma demanda presença e materialidade. A qualificação 'democrática' - que na verdade não é uma qualificação, pois repete como se fosse um adjetivo aquilo que já incluímos no conceito de demanda - aponta para o contexto discursivo/equivalencial, que é a condição da emergência da demanda, ao passo que os qualificativos 'pontual' ou 'isolado' não o fazem”' (Laclau, 2013, p.194). 
são reunidas debaixo de um guarda-chuva mais amplo: quem solicitava iluminação pública e policiamento nas ruas, passa a exigir segurança; quem solicitava o aumento das linhas de ônibus e manutenção do preço das passagens, passa a exigir transporte público de qualidade. O crescimento das demandas populares aparece, via de regra, como sintoma de uma crise institucional; é sinal de que essa sociedade que postula o bem-estar tornou-se incapaz de atender às demandas democráticas e, deixou, portanto, de representar os cidadãos na defesa de seus interesses por mais direitos e qualidade de vida.

Os conceitos de indecidibilidade e deslocamento, discutidos na seção anterior, são importantes para compreender essa dinâmica. Quando as solicitações convertem-se em exigências, as demandas democráticas convertem-se, por sua vez, em demandas populares, mas para que isso ocorra é preciso criar entre as primeiras uma cadeia de equivalências. As demandas populares, quando ganham força suficiente, mostram que as instituições já não são capazes de cumprir com o seu papel de representar os interesses do demos e precisam, portanto, mudar.

Todo esse processo, para Laclau, pressupõe a emergência de um significante vazio - um significante capaz de cancelar as diferenças e criar, em torno de si, um "povo". Um vazio que exerce uma força centrípeta sobre as demandas negadas e produz uma massa para que, dessa forma, possam aparecer positivamente no interior do sistema, agora como demandas populares. Os significantes vazios permitem dar unidade discursiva ao conjunto de demandas heterogêneas, não processáveis pelo sistema (assim como aquilo que, num sistema simbólico, excede o que é diferencialmente representável em seu interior). Essas demandas heterogêneas não se unem ou separam no interior desse sistema: são geradas precisamente por seu deslocamento. Adicionalmente, elas não tendem espontaneamente a aglutinarem-se entre si. "O que lhes confere um laço de equivalência fraco e inicial é o simples fato de que todas elas refletem o fracasso do sistema institucional" (Laclau, 2013, p.169). Para Laclau, é o significante vazio que, ao incorporar esse fracasso, torna presente essa ausência. $\mathrm{O}$ mesmo vale para os significantes flutuantes, que incorporam espectros. $\mathrm{O}$ modelo equivalencial pressupõe essa unidade baseada no equilíbrio instável estabelecido entre as diversas demandas.

Os conceitos de significante vazio e significante flutuante são fundamentais para a compreensão da lógica populista. É por meio deles que esse "laço de 
equivalência fraco e inicial" toma forma e ganha força. Compreender de que modo eles operam na construção das identidades populares é um passo fundamental para responder às perguntas "o que cola?" e "por que cola?" em se tratando de populismos. Para tanto, é necessário atentar para a distinção que Laclau (2013) estabelece entre a forma e a força de um discurso. Os significantes vazios ou flutuantes, na teoria do populismo, funcionam como catalizadores de fluxos afetivos que entram na constituição do "povo"; o que torna o significante desse tipo importante à compreensão do processo de constituição de corpos políticos capazes de afetar e de serem afetados é precisamente o fato dele não ter sentido, mas fazer sentido. Nesse processo, entra em cena a questão do investimento radical ou da catexia - a concentração de todas as forças mentais sobre uma representação específica. Nem todo significante vazio faz sentido, quer dizer, nem todos têm a mesma eficácia para conferir sentido ao conjunto dos significantes. Como aponta o próprio Laclau:

O que a retórica pode explicar é a forma tomada por um investimento sobredeterminante, mas não a força que explica o investimento enquanto tal e sua durabilidade. Aqui algo mais tem que ser colocado em cena. Qualquer sobredeterminação requer não apenas uma condensação metafórica, mas também investimentos catéxicos. Ou seja, algo da ordem do afeto tem um papel primordial na discursividade construída pelo social. Freud já o sabia: o vínculo social é um vínculo libidinal. Um afeto (...) não é algo adicionado à significação, mas algo consubstancial a ela. Portanto, se vejo a retórica como primária, ontologicamente, na explicação das operações inerentes às fórmulas assumidas pela construção hegemônica da sociedade, vejo a psicanálise como o único caminho válido para explicar as pulsões que existem por trás dessas construções - vejo, de fato, como a abordagem mais profícua para entender a realidade humana. (Laclau, 2014, p.326)

A força de um discurso reside, portanto, em sua capacidade de resultar num investimento radical, em sua capacidade de produzir catexia. O investimento radical, como fica claro no trecho supracitado, é algo da ordem do afeto e, para Laclau, o afeto é um dos elementos abarcados pelo seu conceito expandido de discurso, por isso, consubstancial a toda significação: as coisas fazem sentido, porque nos afetam. Parafraseando Espinosa (E3P9Esc), não desejamos e nos esforçamos por algo porque julgamos que é bom, julgamos que é bom porque o desejamos e por ele nos esforçamos. 


\section{4 \\ Nomeação, investimento radical, catexia: o papel do afeto na constituição das identidades populares}

Na teoria do populismo, dimensão afetiva aparece vinculada à questão da nomeação. Conforme discutido anteriormente, a teoria da hegemonia, que está na base do conceito laclauniano de populismo, descarta a existência de estruturas fundamentais que justifiquem esta ou aquela ordem do discurso. Para Laclau, o fundamento das coisas resulta de uma operação de nomeação. A origem dessa abordagem remete ao debate entre descritivistas e antidescritivistas. Para os descritivistas, dentre os quais se encontrava Bertrand Russel, o conteúdo de um nome é determinado por uma constelação de traços descritivos e podem ser de quatro tipos: nomes comuns, de conteúdo descritível, nomes próprios, de conteúdo indescritível, nomes ordinários, que possuem apenas descrição abreviada, e nomes lógicos, que correspondem a categorias dêiticas (dizer, apontar, demonstrar; os nomes lógicos referem-se a pronomes pessoais, demonstrativos, tempos verbais e categorias gramaticais que relacionam enunciados a aspectos de tempo, espaço, pessoa da enunciação e circunstâncias). Para os antidescritivistas, abordados por Laclau a partir da obra de Kripke, as palavras se referem às coisas não em função de seus traços descritivos, mas de um batismo primordial que dispensa inteiramente a descrição. Nomes são designadores rígidos. Nos termos da linguística de Saussure, pode-se dizer que os descritivistas se ocupam de determinações conceituais, ou seja, visam estabelecer relação fixa entre significante e significado. Para os antidescritivistas, o significante não está, de modo algum, sujeito ao significado, mas resulta de uma nomeação. É no campo do antidescritivismo que Laclau inscreve sua teoria do populismo, mas não sem, primeiro, submetê-lo a uma leitura lacaniana, o que ele faz com a ajuda de Slavoj Zizek.

O problema básico do antidescritivismo é determinar o que constitui a identidade do objeto designado para além da constelação sempre mutável dos traços descritivos - o que torna o objeto idêntico a si mesmo, ainda que todas as suas propriedades tenham mudado; em outras palavras, como conceber o correlato objetivo do "designador rígido" para o nome, na medida em que ele denota o mesmo objeto em todas as palavras possíveis, em todas as situações contrafactuais. O que se passa por alto, pelo menos na versão padronizada do antidescritivismo, é que garantir a identidade do objeto em todas as situações contrafactuais - através de uma mudança de seus traços descritivos - é o efeito retroativo da nomeação: é o 
próprio nome, o significante, que sustenta a identidade do objeto. (Zizek apud Laclau, 2013, p.163)

Nessa leitura lacaniana, a nomeação antidescritivista, que é uma teoria da pura designação, ganha outro status ontológico e, quando ocorre, resulta num processo de produção retroativa do objeto, porque é o nome atribuído ao ponto nodal (o point de capiton lacaniano) que o converte no significante vazio capaz de representar a impossibilidade de totalização ou a falta (o objet petit a, de Lacan, objeto que é causa do desejo), aquilo que, na realidade objetiva, procuramos em vão, algo que não possui consistência positiva, que emerge simplesmente como objetificação de um vazio. "Não é através de uma abundância de significados, mas, ao contrário, através da presença de um significante puro que essa função de fixação nodal é preenchida" (Laclau, 2013, p.164). A força do ponto nodal não está em ser, por assim dizer, uma palavra mais rica de sentido, mas em ser uma palavra que condensa toda riqueza de significados de um determinado campo, unificando-o: “é, por assim dizer, a palavra a que 'as coisas' se referem para se reconhecerem em sua unidade" (Zizek apud Laclau, 2013, p.164). Zizek recorre a dois exemplos da publicidade: Marlboro e Coca-Cola. Para o autor, as duas marcas funcionam como pontos nodais na construção da identidade americana. Laclau explica:

\begin{abstract}
No primeiro exemplo, ao se referir aos anúncios do cigarro Marlboro, todas as alusões aos Estados Unidos - "um país de gente forte, honesta, de horizontes ilimitados" - são fixadas nodalmente através de sua relação com o produto: não é que o cigarro Marlboro expresse a identidade americana, mas ela é construída através do reconhecimento dos Estados Unidos como o país do Marlboro. O mesmo mecanismo pode ser observado nos anúncios da Coca-Cola: "Coke, isto é os Estados Unidos" não pode ser invertido para "Estados Unidos, isto é Coke", pois é somente no papel de Coke como puro significante que a identidade norteamericana se cristaliza. (Laclau, 2013, p.164)
\end{abstract}

Nos dois casos, Coca-Cola e Marlboro representam uma falta, mais precisamente, a falta da sociedade americana, um vazio que é causa de desejo. $\mathrm{O}$ que as marcas fazem, ao agrupar sentidos em torno de si (o país de gente forte, honesta e de horizontes ilimitados) é representar esse objeto que é causa do desejo - esse objeto $a$, essa impossibilidade de totalização da sociedade, tão importante na teoria do populismo de Ernesto Laclau.

As totalizações, enquanto representações da totalidade, são essas tentativas de limitar o jogo, de domesticar a infinitude e abarcá-la numa ordem ou estrutura 
finita. Elas não estabelecem os limites "do social" ao fazer dele um objeto determinado: o social sempre excede os limites das tentativas de constituição da sociedade. Embora se trate de lacuna impossível de ser eliminada, nada impede que haja tentativas de "sutura", que permitam uma fixação relativa do social por meio do que Laclau denomina pontos nodais. É nesse sentido que, da perspectiva da hegemonia, todo discurso se constitui como tentativa de "dominar o campo da discursividade", conter o "fluxo das diferenças e construir um centro" (Laclau e Mouffe, 2015). Esse centro, nas palavras de Laclau, não pode ser determinado $s u b$ species aeternitatis: "cada formação social tem suas próprias formas de determinação e relativa autonomia, sempre instituídas por meio de um processo complexo de sobredeterminação e, portanto, não pode ser definido a priori”" (Laclau, 1990, p.91). É em relação a essa concepção de sociedade que Laclau contesta a crítica da ideologia como falsa consciência, uma vez que não haveria fundamento a ser descoberto ou revelado. É nesse sentido, também, que se pode dizer que Coca-Cola e Marlboro não são meros reflexos da ideologia americana, mas estão na base mesma dessa sociedade. A ideologia, para Laclau, não consiste na incapacidade de reconhecer a essência positiva da sociedade - que, em última instância, não existe - mas em não reconhecer "o caráter precário de toda positividade, a impossibilidade de qualquer sutura definitiva". (Laclau, 1990, p.92)

Para Laclau, as identidades populares fundamentam-se nessa dimensão performativa da nomeação. É ela que unifica um determinado campo, é em torno do puro significante, o significante vazio, que a identidade se cristaliza. Laclau remete o papel do significante vazio à função exercida pelo zero de Pascal, teorizado por Paul de Man: “'Zero’ é a ausência do número, mas, ao dar um nome a essa ausência, estou transformando o 'zero' em 'um'” (Laclau, 2013, p.166). Para Laclau, no processo de construção das identidades populares, esse papel do zero é desempenhado por um conteúdo parcial (uma parte) que "assume a representação de uma universalidade em relação à qual ele é incomensurável" (Laclau, 2013, p.167). Isso pode ser observado nos exemplos da Coca-Cola e do Marlboro que, embora funcionem como pontos nodais que totalizam uma certa significação, não deixam de ser, também, enquanto marcas, entidades particulares. Há, nessa relação, uma contaminação mútua entre universalidade (do ponto nodal) e a particularidade (da marca) - como no caso do corpo e do espírito, na 
manifestação do espectro. Não se pode privar as marcas de sua identidade particular, nem confiná-las ao papel de ponto nodal. O mesmo fenômeno ocorre, para Laclau, na operação hegemônica que dá origem às identidades populares. Nelas, é sempre uma particularidade que passa a representar a universalidade, uma parte que representa o todo: a hegemonia se constitui como sinédoque.

Tal sinédoque, no entanto, não consiste numa operação meramente linguística, dada a concepção laclauniana de discurso, que, conforme já visto, sempre envolve uma articulação entre palavras e ações, algo da ordem dos jogos de linguagem, na teoria do segundo Wittgenstein. Para Laclau, a articulação universalidade/particularidade, que se dá no nível das palavras e imagens, está sempre sedimentada em práticas e instituições (Laclau, 2013). Ou seja, na construção das identidades populares, a função nodal está sempre inserida em "práticas materiais que podem adquirir uma fixidez institucional" (Laclau, 2013, p.168). Para o autor, isso equivale a dizer que

(...) qualquer deslocamento hegemônico deveria ser concebido como uma mudança na configuração do Estado, contanto que esse seja concebido não em um sentido jurídico restritivo, mas como esfera pública, num sentido gramsciano amplo, como momento ético-político da comunidade. Qualquer Estado manifestará a combinação de particularismo e universalidade, que é inerente à operação hegemônica. (Laclau, 2013, p.168, grifo meu)

O deslocamento, nesse caso, parece sinalizar uma distância entre as instituições e práticas que constituem um determinado Estado e os anseios éticopolíticos da plebs. É isso que configura o desejo que leva a parte (a plebs) a querer se apossar do todo (o populus) para poder modificá-lo, transformá-lo, desenhá-lo de outro modo, mais a seu gosto. Para Laclau, esse desejo popular não surge como resultado de uma transição lógica ou dialética (considerando-se o contexto pósmarxista em que está inscrita sua teoria, pode-se dizer que tudo que ele não quer é que a transição hegemônica seja compreendida como mero reflexo da infraestrutura na superestrutura). Laclau defende que, para que isso aconteça, é necessário a intervenção de algo qualitativamente novo, que ele associa precisamente ao efeito retroativo da nomeação e ao investimento radical que nela pode vir a ser feito. Volta à cena, neste ponto, a questão da catexia, agora devidamente atrelada à questão do batismo primordial. 
De acordo com Laclau, as operações (os nomes, os significantes vazios, os significantes flutuantes etc.) dizem respeito à forma de um discurso. Sua força, no entanto, provém dos afetos que são capazes de mobilizar: "qualquer todo social resulta de uma articulação entre dimensões significantes e afetivas" (Laclau, 2013, p.174). É importante notar ainda que, para o autor, “o afeto não é algo que existe por si próprio, independente da linguagem. Ele se constitui somente através da catexia diferencial de uma cadeia de significação" (Laclau, 2013, p.173). É precisamente isso que Laclau entende por investimento radical.

$\mathrm{Na}$ teoria do populismo, essa dimensão afetiva é abordada a partir do referencial psicanalítico. É baseado nesse referencial que o que ele chama de efeito retrospectivo da nomeação será aprofundado. Laclau recorre sobretudo à obra de Joan Copjec em sua argumentação. Num artigo dedicado à análise psicanalítica da tragédia Antígona, Copjac traz à baila o conceito de pulsão de morte, na teoria freudiana, de um modo que interessa a Laclau. Para Freud, argumenta a autora, a morte seria o objetivo de toda pulsão, na medida em que aponta para um passado idílico, uma plenitude perdida no momento em que o sujeito abandona o útero materno e, uma vez inserido no tempo, passa a caminhar em direção à morte. Para Copjac, tal estado de inanidade ou inércia funciona como uma ilusão retrospectiva, que ela relaciona ao mito do Timeu, "no qual a terra, sendo um globo que tudo abrange, não precisa de qualquer espécie de órgão - ela não tem um exterior” (Laclau, 2013, p.174). É fácil perceber como essa imagem invocada por Copjac se relaciona com a impossibilidade da sociedade, teorizada por Laclau. Da perspectiva psicanalítica, assumida pela autora, essa ilusão retrospectiva - não é nenhuma grande surpresa - é interpretada nos termos de uma relação entre mãe e fillho, para a qual o sujeito se esforça para retornar; a plenitude que se espera encontrar no futuro e se constrói no presente é algo que se encontra, em realidade, no passado: é uma plenitude uterina. Para Laclau, é essa ideia de plenitude que as demandas insatisfeitas reproduzem enquanto presença de uma ausência (Laclau 2013).

$\mathrm{Na}$ análise de Copjac, o que impede que a pulsão de morte seja levada ao extremo da destruição é a dinâmica do objeto parcial; em primeiro lugar, porque não existe uma pulsão única e completa, existem apenas pulsões parciais, motivadas por objetos parciais; e, em segundo lugar, porque a própria atividade da pulsão inibe esse objetivo, uma vez que seu objeto, na medida em que o sujeito a 
ele se prende, funciona como um obstáculo que "simultaneamente freia a pulsão e a desfaz, a restringe, a impede de atingir seu objetivo e divide-a em pulsões parciais" (Copjac apud Laclau, 2013, p.175). Assim, conclui Laclau, "as pulsões contentam-se com esses objetos parciais que Lacan denomina objetos $a$ " (Laclau, 2013, p.175). Para o autor, dinâmica similar ocorre na construção das identidades políticas, que se construiriam como objetos parciais.

Como aponta Laclau, a argumentação de Copjac articula conceitos de Freud e Lacan. A ilusão retrospectiva remete tanto a Nebenmensch (a mãe primordial, o Outro como primeiro objeto de satisfação) quanto à divisão inicial entre aquilo que é representável e a Das Ding, a Coisa, a plenitude inalcançável, na teoria freudiana. Para Freud, existe algo dessa mãe primordial que é impossível traduzir na representação, o que abre uma brecha no significante. Se parássemos por aí, sinaliza Laclau, o que teríamos seria a oposição kantiana entre o númeno e a representação fenomênica, entre ser e pensar. Daí, ele acredita, a importância da teoria lacaniana como saída para esse impasse, pois, para Lacan, "a Coisa perdida não é uma impossibilidade de pensamento, mas um vazio do ser" (Laclau, 2013, p.175).

Para Lacan, não é a mãe primordial que escapa à representação ou ao pensamento, o que escapa é o gozo, a jouissance, justamente aquilo que nos mantinha ligados a ela. O gozo, no entanto, não se perde completamente: traços dele se nos apresentam nos objetos parciais. Esses traços, no entanto, já não obedecem ao esquema númeno-fenomênico da representação. Isso porque "[o] objeto parcial torna-se em si mesmo uma totalidade, torna-se princípio estruturante de toda a cena" (Laclau, 2013, p.176).

$\mathrm{Na}$ formulação de Copjec, aponta Laclau (2013), o objeto parcial não emerge como uma parte do todo, mas como uma parte que é o todo. Para ilustrar essa concepção, ela recorre aos estudos de Gilles Deleuze e Bella Balász sobre o cinema, onde o close-up é concebido não como detalhe de um todo, mas como um detalhe por meio do qual toda cena é redimensionada ${ }^{6}$. Desse modo, observa

\footnotetext{
6 "Deleuze sustenta que o close-up não é um olhar mais detido sobre uma parte da cena, isto é, ele não revela um objeto que pode ser incluído como um elemento daquela cena, um detalhe pinçado do todo e então ampliado com a finalidade de focar nossa atenção. O close-up desvenda o todo da própria cena ou, como afirma Deleuze, seu total "expressado" [...]. Eu diria que o objeto parcial da pulsão exemplifica a mesma lógica, ele não faz parte do organismo, mas implica uma mudança absoluta" (Copjec apud Laclau, 2013, p.177).
} 
Laclau, o objeto parcial não deixa de ser compreendido como uma parcialidade que evoca uma totalidade: ele é o nome dessa totalidade. Para Copjec, a díade mãe/filho desaparece no gesto lacaniano de introduzir aí um terceiro componente, o seio que, desligado da mãe, converte-se no objeto da pulsão. Para a autora, a falta, na teoria lacaniana, não pode ser compreendida fora do mito timeano/lamelliano no qual tem origem. Lacan descreve a lamella (traduzida também como lâmina, para o português) como algo achatado que se desloca como uma ameba. Algo que passa por toda parte e tem relação com aquilo que o ser sexuado perde na sexualidade. É algo como a ameba em relação aos seres sexuados. Imortal, porque sobrevive a qualquer divisão. A lamella pode ser associada à libido

enquanto puro instinto de vida, quer dizer, de vida imortal, de vida irrepreensível, de vida que não precisa, ela, de nenhum órgão, de vida simplificada e indestrutível. É o que é justamente subtraído ao ser vivo pelo fato de ele ser submetido ao ciclo da reprodução sexuada" (Žižek, 2006, 77).

O objeto parcial, objeto da falta, emerge do vazio deixado pela perda da plenitude, do Das Ding original. A satisfação que o sujeito experimenta já não deriva mais da unidade com a Coisa materna, mas daquilo que ele encontra agora no objeto parcial, concebido, em termos lacanianos, como um objeto ordinário promovido ao status da Coisa.

A elevação do objeto externo da pulsão - fiquemos com o exemplo do leite - ao status de seio (isto é, ao status de um objeto capaz de satisfazer algo mais do que a boca ou o estômago) não depende de seu valor social ou cultural. Seu "valor de seio" excedente, digamos assim, depende somente de a pulsão elegê-lo como um objeto de satisfação. (Copjec apud Laclau, 2013, p.178)

Se Laclau se apoia tanto em categorias oriundas da psicanálise é por acreditar que elas pertencem a um campo que, para ele, poderia ser denominado de ontologia geral (Laclau, 2013, p.178). Reconhecendo, no entanto, que tais categorias podem, muitas vezes, ser causa de estranhamento, o autor é bastante cuidadoso na tradução desses conceitos para o âmbito da teoria política. Ele esclarece, num texto que merece ser mencionado in extenso:

A plenitude mítica da díade mãe/filho corresponde à plenitude não alcançada, evocada - como seu oposto - pelo deslocamento ocasionado pelas demandas não 
atendidas. Entretanto, a aspiração a essa completude ou plenitude não desaparece simplesmente. É transferida a objetos parciais, que são objetos das pulsões. Em termos políticos, isso é exatamente o que denominei relação hegemônica: certa particularidade que assume o papel de uma impossível universalidade. Devido ao fato de que o caráter parcial desses objetos não resulta de uma história particular, mas é inerente à própria estrutura da significação, o objeto $a$ de Lacan é o elemento-chave numa ontologia social. O todo sempre será corporificado por uma parte. Em termos de nossa análise, não existe universalidade que não seja hegemônica. Há, porém, algo mais. Como nos exemplos dos close-ups e do "valor de seio" do leite, discutidos por Copjec, nada existe na materialidade das partes predeterminando que uma ou outra funcionem como um todo. No entanto, uma vez que certa parte assumiu semelhante função, é sua própria materialidade enquanto parte que se tornará uma fonte de gozo. Gramsci formulou seu argumento político em termos parecidos: a força social que se tornará a representação hegemônica da sociedade como um todo resulta de uma luta contingente, mas, uma vez que determinada força social se torna hegemônica, ela assim permanecerá durante todo um período histórico. $O$ objeto do investimento pode ser contingente, mas certamente não é indiferente, não pode ser mudado à vontade. Com isso chegamos a uma explicação completa do que significa investimento radical: tornar um objeto a corporificação de uma plenitude mítica. O afeto - isto é, o gozo - é a própria essência do investimento enquanto seu caráter contingente dá conta do componente "radical" da fórmula. (Laclau, 2013, p.178-9, grifos meus)

Podemos perceber que toda argumentação em torno do populismo converge nesse ponto. Na base desta construção, deste edifício teórico, o que encontramos é o investimento radical, o gozo, a jouissance ou, simplesmente, o afeto. Como se pode argumentar, de uma perspectiva freudiana, todo laço social é um laço libidinal $^{7}$. Essa compreensão nos permite avançar na direção de uma possível resposta para uma das perguntas colocadas no começo desse trabalho: o que cola num discurso - seja ele populista ou não? A questão que permanece na obscuridade ainda é outra: como cola? O que determina um investimento radical num ou noutro objeto parcial? O que determina adesão a um ou outro discurso? Para Laclau, é essa pergunta que parece ficar em aberto.

\section{5 \\ Lacan e as aventuras do afeto}

O diálogo entre Laclau e Stavrakakis abre uma série de perspectivas para compreendermos melhor o protagonismo dos afetos na determinação da força de um discurso. Este diálogo se dá, principalmente, a partir do referencial lacaniano

\footnotetext{
${ }^{7}$ Outra forma de afirmar a mesma coisa é dizendo, de uma perspectiva espinosista, que toda relação é estabelecida pelo desejo, ou, ainda, dizendo, com Safatle (2016), que na base de todo corpo político encontra-se um circuito de afetos.
} 
mobilizado por ambos. Essa é uma das razões pelas quais o debate ocorre, especialmente, em torno do conceito lacaniano de jouissance.

A palavra afeto é pouco utilizada por Lacan, o que contribuiu para sua fama - injusta, no entender de Stavrakakis - de pensador que, em nome de uma abordagem centrada na linguagem, teria preterido a dimensão afetiva, o que resultaria numa "análise estéril da qual raiva, vergonha, piedade, indignação, inveja e ciúme teriam sido banidos" (Gallagher apud Stavrakakis, 2007, p.88). Stavrakakis enumera algumas dessas críticas, bem como declarações do próprio Lacan, uma delas contida no primeiro Seminário, em que ele fala do afeto como "referência imaginária" e afirma, em conversa com Serge Leclaire: "Eu acredito que esse é um termo que deveria ser completamente expurgado de nossos artigos" (Lacan apud Stavrakakis, 2007, p.89).

Apesar da assertividade da frase, Stavrakakis pondera que seu alvo não é a dimensão afetiva em si, mas um entendimento específico do afeto como oposto ao intelecto (ou à razão). Isto aparece num alerta dirigido aos participantes do Seminário:

Eu os incentivo, cada um de vocês, no coração de suas próprias pesquisas, a renunciar radicalmente... o uso de uma oposição como essa do afetivo e do intelectual... essa oposição é uma das mais contrárias à experiência analítica e a menos esclarecedora quando se pretende compreendê-la. (Lacan apud Stavrakakis, 2007, p.89).

Como aponta Stakravakis (2007), essa é uma rejeição semelhante àquela de Laclau, quando se opõe à distinção entre afeto e discurso, procurando evitá-la por meio de seu conceito expandido de discurso. Em Lacan, essa recusa aparece no caminho de "retorno a Freud", que procura dar conta dos mecanismos de significação, como condensação e deslocamento, envolvidos na criação da realidade humana na teoria freudiana, e reformulá-los com ajuda da linguística e do estruturalismo. "Seu principal esforço é ressaltar a constitutividade do simbólico na vida humana" (Stavrakakis, 2007, p.89). A famosa frase em que Lacan postula que o inconsciente se estrutura como linguagem é dessa época, em que o desejo, em Freud, é reduzido ao significado, o terreno do afeto e do gozo é reduzido à questão do significante (ou do falo). O caso, no entanto, não estava encerrado. $\mathrm{Na}$ verdade, como argumenta Cormac Gallagher, citado por Stavrakakis (2007), a renúncia de Lacan aos termos em algumas partes do 
seminário de 1953-54 é "provisional e temporária" (Stavrakakis, 2007). Para esse autor, o afeto é uma das principais preocupações da teoria lacaniana e já aparecia nos textos sobre o complexo familiar, escritos para a Encyclopédie Française, em 1938, assim como em todo seminário dedicado à ansiedade (1962-63). Stavrakakis argumenta que mesmo antes do Seminário da Ansiedade há uma fase transicional, em Ética da Psicanálise (1959-60) em que, na discussão sobre a Coisa, a Das Ding de Freud, tem início uma "quebra do monopólio da significação" (Stavrakakis, 2007, p.90). A Das Ding é descrita por Lacan, nesse seminário, como algo "obscuro" e carente de "pontos de referência" devido à "falta de organização de seu registro", algo "mais primitivo" e "opaco", associado com a "metafísica analítica" e às noções "concernentes à energia"; a afetividade começa a aparecer aí como algo que está para além da significação, algo cuja importância não pode ser negada, mas que não pode ser confundido com a substância procurada no Real, algo que está além das "articulações significantes", com as quais os "artistas do discurso analítico" não são capazes de lidar (Lacan apud Stavrakakis, 2007, p.90). O afeto ressurge, portanto, como um território confuso e enganador.

\begin{abstract}
Há, no entanto, uma importante diferenciação a ser feita nos termos das bases exatas nas quais a afetividade é rejeitada. Dessa vez isso não acontece porque a ênfase nos afetos é distanciada daquele registro de um campo de significação abrangente ou porque se nega seu valor, algo que a rejeição anterior parecia implicar. Mais interessante, a afetividade é rejeitada precisamente pelas razões opostas, a saber, por não estar suficientemente distante, por causa do "caráter convencional e artificial dos afetos". Com a distinção entre emoção e afeto esse quadro vai mais tarde se modificar decisivamente, levando à posição final encontrada no seminário sobre Ansiedade: "O que é a ansiedade? Nós nos acostumamos a descrevê-la como uma emoção. E, para introduzi-la, eu diria que é um afeto". (Stavrakakis, 2007, p.90-1)
\end{abstract}

Stavrakakis atribui essa mudança radical a uma falha da redução significante implícita na estratégia inicial de Lacan, a de um retorno predominantemente estruturalista a Freud. Para Stavrakakis, a persistência do afeto como uma questão para Lacan se deve ao fato de que a prioridade conferida ao significante não impede que algo escape à significação - um excedente, um resto, um resíduo que denuncia seu caráter parcial e exige uma reflexão rigorosa em torno do gozo como "algo distinto, irredutível ao significado, ao simbólico" (Stavrakakis, 2007, p.92). Essa constatação traz de volta ao palco lacaniano um 
elemento central para a metapsicologia de Freud, aquela que postula "a disjunção entre o nível somático da excitação e aquela de suas representações na psique" (Stavrakakis, 2007, p.92). A substituição do falo pelo objet petit a, um dos nomes dado por Lacan a esse "excesso", é, para Stavakrakis, apenas uma das maneiras que Lacan utiliza para abordar posteriormente esse assunto.

Uma das preocupações de Lacan, que Laclau compartilha, segundo Stakravakis, é a de evitar uma abordagem dualista dessa questão. Lacan, no entanto, não descarta uma dualidade relacional. Ele opera com uma alternância de enfoque, que procura dar conta da transição do real ao somático, visando suplantar, desse modo, os problemas identificados na metapsicologia, onde "a relação entre energia libidinal, a fronteira somática da pulsão e a representação, bem como o modus operandi entre as duas, nem sempre é claramente definida em Freud" (Stavrakakis, 2007, p.92). O que se tem não é uma separação definitiva, mas um emaranhado que é possível e necessário tentar desfazer, analisando as duas instâncias separadamente, mas tendo em conta a "extimidade" dessa relação: a indissociabilidade constituinte entre interior e exterior ${ }^{8}$.

A questão que se coloca em seguida, entretanto, diz respeito ao "antes": ainda que reconheçamos a existência de um conteúdo pré-simbólico ou extradiscursivo, como falar daquilo que é anterior à representação? Estamos diante do problema do "irrepresentável". De algo que, embora saibamos que exista, não somos capazes representar, seja porque nos escapa, no momento em que o representamos, seja porque excede essa representação. Para tentar dar conta desse problema, Lacan introduz uma analogia

(...) entre a energia real pré-simbólica e a operação de uma represa hidrelétrica. Como Richard Boothby observa, é impossivel especificar e calcular a energia do rio sem se referir à estrutura da represa que vai obstruir e redirecionar seu fluxo. Nós podemos e devemos pressupor a força do rio, mas essa força não é acessível para nós em nenhum sentido sem o mecanismo da barragem, ou seja, sem erigirmos um obstáculo em relação ao qual a força possa ser sentida. (Stavrakakis, 2007, p.93, grifos meus)

O paradoxo da metapsicologia consiste no seguinte: é necessário pressupor um substrato energético pré-simbólico, anterior à representação, que, por outro

\footnotetext{
${ }^{8}$ Isso remete ao emaranhado pragmático-semântico que informa o conceito expandido de discurso na obra de Laclau, para quem “(...) a semântica é inteiramente dependente dessa pragmática, da qual pode ser separada - quando muito - apenas analiticamente" (Laclau, 1990, p.102). Laclau, no entanto, parece menosprezar a importância dessa analítica.
} 
lado, não pode ser significado sem remeter a um objeto de investimento ou a uma repressão. "Em outras palavras, pressupor uma energia psíquica é algo inevitável, mas também, por necessidade, indeterminado" (Stavrakakis, 2007, p.93). A solução lacaniana para esse paradoxo tem uma dupla face: por um lado, podemos ter acesso aos limites do discurso (o afeto e a jouissance) graças aos traços que eles deixam no discurso e na representação; por outro, a irredutibilidade do Real o $\mathrm{X}$ do real - deve ser assinalada, mesmo que isso introduza na teoria um elemento metafísico (Stavrakakis, 2007, p.93). Essa hipótese se apresenta, portanto, como uma ficção necessária, sem a qual é impossível lidar com o Real contido nessa dimensão pré-simbólica, extradiscursiva - que remete à Das Ding freudiana e está, na teoria lacaniana, ilustrada pelo mito da lamella - com a qual o discurso interage mas que, ao mesmo tempo, o excede. É nesse contexto que surgem conceitos como lalangue, sintoma e fantasia. O caminho encontrado por Lacan para ultrapassar a linguagem, em direção ao que está além dela, por meio da própria linguagem, levando-a ao limite, (numa espécie de "aceleracionismo" linguístico) tomando-a, fantasiosamente, por algo que ela não é, ou seja, uma entidade onipotente que a tudo abarca. Só assim se chega ao além-linguagem - ou ao “deserto do Real”, pra usar a expressão cara à Slavoj Zizek.

\footnotetext{
Essa inversão requer uma exaustão da linguagem: nós precisamos imergir na mais extensiva conceitualização da linguagem, para levar em conta os múltiplos caminhos pelos quais ela determina/produz nossa realidade para sermos capazes de vislumbrar o que está além da linguagem mas, todavia, em relação com ela [...]. A jouissance não pode ser reduzida a um processo natural, portanto, só depois de exaurir o campo linguístico é possível falar propriamente em jouissance. Não há paradoxo aqui: nós só podemos nos mover para além da linguagem na medida em que reduzimos tudo à linguagem; se essa redução significante deixa restos de real, eles precisam ser considerados da maneira mais extrema, mesmo que isso envolva uma radical inversão. (Stavrakakis, 2007, p.94)
}

Em seus textos tardios, Lacan já se referia à linguagem como blá blá blá ou mesmo como um "parasita dos seres humanos", assinala Stavrakakis (2007, p.94), baseado nos comentários de Jacques-Alain Miller, editor francês dos Seminários. Tanto o conceito de linguagem quanto o de estrutura perderam importância na teoria lacaniana, preteridos em relação ao Real que, por meio das tipologias da 
jouissance, se tornou uma espécie de força bruta, algo equivalente ao Drang da pulsão freudiana ${ }^{9}$.

Os textos e seminários tardios de Lacan conferem à jouissance uma prioridade causal sobre o significante. "Não só os dois planos são distintos, e mesmo antitéticos, como a jouissance é também teorizada como aquilo que relega o simbólico ao status de semblant imaginário" (Stavrakakis, 2007, p.95). Só depois de superar o estágio em que o simbólico ocupa o primeiro plano em direção a um segundo momento, no qual a fantasia é atravessada e o Real reaparece, enfim, restituído de seu poder causal; só depois de todas essas etapas é que se torna possível, na teoria lacaniana, compreender a interpenetração entre os domínios do Real (jouissance) e do simbólico (significação), num processo que não prescinde da fantasia (imaginário). Toda tríade lacaniana encontra-se, portanto, implicada nesse processo. É só por meio dessa dinâmica, postula Stavrakakis (2007) que a significação pode ser reconceitualizada com o recurso das categorias lacanianas de significance, jouis-sens e lalangue, três dos (muitos) neologismos que Lacan utiliza representar os limites paradoxais em que jouissance e linguagem se confundem.

Segundo Stavrakakis, a lalangue sublinha a força de uma linguagem não linguística: uma linguagem pré-simbólica que se encontra antes da linguagem e depois da linguagem. Antes, como o balbuciar de uma criança, que Lacan situa entre a jouissance e a linguagem, entre necessidade e demanda; depois, como aquele resto ou resíduo que resiste à castração imposta pelo simbólico, aquilo que não pode ser processado por meio dele e que nele deixa alguns traços. Esses traços, aponta Stavrakakis, se revelam numa variedade de construções discursivas que operam, para Lacan, na fronteira do discurso socialmente aceitável: "na linguagem privada dos amantes, na linguagem paroxística da magia (o que significa 'abracadabra'?)” (Stavrakakis, 2007, p.95). A lalangue é o não comunicável na linguagem, aquilo que, por meio da ambiguidade ou da homofonia, revela os aspectos afetivos que nela persistem e que nos afetam, sobretudo, por tudo que trazem à tona: "por meio de efeitos que são afetos" (Lacan apud Stavrakakis, 2007, p.95). Com base nesses elementos da teoria

\footnotetext{
${ }^{9}$ Em o Instinto e suas Vicissitudes (1915), Freud (1996) identifica três elementos na pulsão: pressão (Drang); finalidade ou objetivo; e objeto ou fonte. A pressão (Drang) é, desses, o elemento em que funciona o motor da pulsão; determina a quantidade de força ou exigência do trabalho que ela representa.
} 
lacaniana, torna-se possível abordar afeto e discurso como dimensões distintas, mas inter-relacionadas, desde que se evite uma abordagem "melosa" do afeto e que não se perca de vista sua relação com a significação e o significado.

$\mathrm{O}$ primeiro tem que ser visto como modificado e direcionado pela ordem simbólica, por meio da representação, que é por sua vez limitada e distorcida por sua pressão, pela persistência da pulsão ou da irredutibilidade do gozo. Parece, então, que fizemos algum progresso. Na verdade, terminamos numa posição muito similar à de Laclau, em sua segunda linha de resposta: há, de fato, dois lados, mas eles só podem ser explorados em sua mútua relação. Indubitavelmente; mas é importante ressaltar mais uma vez que a relação perde todo seu sentido sem o risco de posicionar os dois lados como ontologicamente êxtimos [extimate] um ao outro. É por isso que a trajetória complexa de Lacan vis-à-vis à exata formalização da dialética entre o real e o simbólico é tão crucial aqui. Ao ultrapassar a fantasia de um simbólico que a tudo abarca, Lacan assume o risco impossível de positivar o real, o que inclui necessariamente as necessárias limitações, ou mesmo o fracasso, desse processo - limitações impostas por nosso aprisionamento no simbólico (mas um simbólico, por sua vez, partido por uma divisão real). É o fracasso de reduzir o real ao simbólico e o simbólico ao real e admissão de ambos esses momentos irredutíveis que permite um novo insight sobre seu complexo modo de interação. (Stavrakakis, 2007, p.96)

O que Laclau procura evitar a todo custo é cair no essencialismo. Essa preocupação é expressa e justificada por Laclau num texto publicado no Journal of Lacanian Studies, em resposta a um artigo de Stakravakis e Jason Glynos, publicado anteriormente no mesmo periódico. No texto, mais tarde reproduzido parcialmente em Laclau: a critical reader, Laclau escreve o seguinte:

Primeiro, se o afeto for visto como uma intrusão estrangeira na linguagem, pode parecer que essa última teria sido capaz de alcançar uma plenitude por conta própria se a interrupção não tivesse acontecido - ainda que a interrupção seja inevitável. Esse é o melhor caminho para conduzir a uma concepção puramente essencialista/estruturalista da linguagem. (Laclau, 2014, p.303)

Stavrakakis contra-argumenta que afeto e jouissance "não são experimentados apenas como meras intrusões, mas também como investimentos que infundem significação, fortalecem significados e discursos"10 (Stavrakakis, 2007, p.96) e, por outro lado, diz que não consegue ver de que modo a insistência

\footnotetext{
10 "A capacidade de plenitude do simbólico já é negada pela totalidade da conceitualização lacaniana sobre a falta constitutiva do Outro - mas, e esse é um passo crucial, essa falta tem que ser conhecida em sua dimensão real inequívoca, como uma falta de jouissance que dá início a toda dialética de interrupções/interimplicações entre jouissance e linguagem, afeto e representação. Ao mesmo tempo, ainda que esse resíduo do real e suas implicações híbridas no interior da linguagem pressuponham um real êxtimo [extimate], esse real é por definição impossível de representar em sua totalidade: faltam meios para isso no campo da representação.” (Stavrakakis, 2007, p.97)
} 
no caráter distinto de um e outro pode levar a uma concepção essencialista/estruturalista da linguagem ${ }^{11}$. Para ele, o que oferece esse risco é justamente o conceito expandido de discurso defendido por Laclau, que torna impossível distinguir os dois lados da dualidade discurso/afeto, pois tudo nela se torna um momento interno ao discurso. Dessa perspectiva, argumenta o autor: "O desenvolvimento, a história contingente de um conjunto discursivo, se torna resultado de uma dinâmica endógena, especialmente se o extradiscursivo permanece fora do campo da reflexão" (Stavrakakis, 2007, p.98). Com este poder de tudo encampar, aquilo que deveria ser concebido em termos históricos e contingentes, a saber, o discurso, ganha contornos ontológicos e tudo mais passa a resultar de sua dinâmica endógena, imanente a ele, "especialmente se o extradiscursivo fica de fora do campo da reflexão" (Stavrakakis, 2007, p.98).

Mais relevante que a acusação de imanentismo - que, a depender da perspectiva, pode ser encarado menos como um problema e mais como uma qualidade da teoria de Ernesto Laclau - a crítica mais pertinente de Stavrakakis, no âmbito deste trabalho, é a que aponta para a maneira como, nesse conceito expandido de discurso, o extradiscursivo permanece, paradoxalmente, muitas vezes fora do campo da reflexão. E, nesse movimento, que o afeto, embora reconhecidamente central para a compreensão das identidades populares, fica por demais apartado ao ser inscrito no âmbito do irrepresentável. Por vezes, é como se os objetos parciais não fossem elegidos dentre coisas efetivamente existentes. Tomando a imagem lacaniana, mobilizada por Laclau via Copjec, podemos nos perguntar se, ainda que todo objeto parcial seja reduzido ao seio, será mesmo impossível identificar diferenças entre um leite e outro? A sensação que emerge, muitas vezes, ao longo da leitura de A Razão Populista, e mesmo de Hegemonia e Estratégia Socialista, é a de que, na ânsia de se livrar do fantasma do determinismo econômico, Laclau e Mouffe tivessem forçado demais a barra na direção oposta, dando uma ênfase excessiva ao caráter aberto de toda identidade

\footnotetext{
11 "De modo breve, argumentar que não estamos lidando com duas ordens de fenômenos conceitualmente - e mesmo ontologicamente - distintos não pressupõe o passo posterior de concluir que essas duas ordens só podem ser pensadas como entidades essencialistas e autocontidas. Se há perigo de essencialismo aqui, ele só pode resultar da concepção abrangente de discurso que Laclau defende em sua primeira linha de resposta. Na realidade, o que é mais surpreendente é que é possível até mesmo detectar traços de uma lógica imanentista nessa concepção - o que é surpreendente porque Laclau tem sido um dos críticos mais eficientes do, em última instância, antipolítico cul-de-sac do imanentismo como articulado, por exemplo, no trabalho de Hardt e Negri (...)" (Stavrakakis, 2007, p.98)
} 
política, de toda relação hegemônica. É possível que isso se deva não apenas à posição pós-marxista, assumida pelos autores, mas, em grande medida, também, à afinidade de ambos com a crítica pós-estruturalista, que se aproxima, por sua vez, em muitos aspectos da crítica pós-moderna das metanarrativas. Há que se reconhecer, no entanto, que nada disso é negado pela dupla. O pós-marxismo é, para ambos, motivo de orgulho, como eles declaram expressamente, por exemplo, num artigo intitulado Post-Marxism without apologies (Laclau, 1990).

Ao encampar as críticas de Stavrakakis, o que se pretende aqui não é retornar a uma concepção determinista da história ou ao economismo que marcou boa parte da tradição marxista ao longo do último século e hoje em dia, embora agonize, não morre. Tampouco se pretende aqui restituir o lugar privilegiado do proletariado como sujeito dessa história. Se tantas páginas foram dedicadas até o presente parágrafo para apresentar as ideias de Laclau e Mouffe sobre processo de construção das identidades políticas é porque se considera, aqui, que os conceitos desenvolvidos por esses autores são ferramentas teóricas fundamentais para compreender tais processos no mundo contemporâneo. Importa evitar, no entanto, pender a balança demais para o lado oposto, ou seja, da absoluta determinação do político pelo econômico para a absoluta autonomia. Até porque, como o próprio Laclau reconhece, em trecho supracitado: "O objeto do investimento pode ser contingente, mas certamente não é indiferente, não pode ser mudado à vontade" (Laclau, 2013, p.179). E é por isso, por exemplo, que o populismo, por sua vez, eclode em momentos de crise institucional, onde se observa um deslocamento em que ele ao mesmo tempo depende e estimula. Não interessa aqui, portanto, recusar o trabalho de Laclau sobre o populismo. Subscreve-se praticamente tudo que ele diz sobre a construção das identidades populares. Interessa, no entanto, dar um pequeno passo atrás, a fim de observar o que ocorre no momento imediatamente anterior ao corte populista. Isso porque a teoria do populismo explica como um discurso cola, mas só nos permite pensar do colar em diante. Ela não parece capaz de indicar onde devemos procurar os elementos a partir dos quais se possa construir um discurso que cole, nem tampouco ajuda a entender porque determinados discursos colam e outros não. Se o que se pretende é pensar o potencial do populismo para a organização política, essa é uma questão fundamental. Curiosamente, é possível encontrar no próprio Laclau, graças, inclusive, ao seu conceito expandido de discurso, alguns subsídios passa pensar 
esse momento que antecede o corte populista e é, ao mesmo tempo, sua condição de possibilidade.

Num artigo em que explora a relação de complementaridade entre metonímia e metáfora em Em Busca do Tempo Perdido, de Proust, Laclau (2010) se apoia nos estudos de Gerard Genette sobre a obra do romancista francês para argumentar que as metáforas proustianas sempre aparecem ligadas a uma cadeia de metonímias que lhes assegura não apenas um efeito de totalidade, como lhes confere, também, certa materialidade. Tal materialidade se deve à relação espacial de contiguidade, característica da operação metonímica que, para Laclau, "é a fonte dos efeitos analógicos da metáfora" (Laclau, 2010, p.54). Em outras palavras, é o que faz a analogia fazer sentido. Metonímia e metáfora sustentam-se mutuamente no ponto de tensão produzido por esse encontro. Recorrendo a uma série de exemplos extraídos da obra proustiana, Genette sugere que a mútua implicação dessas duas figuras de linguagem é que confere "unidade ao espaço discursivo" (Laclau, 2010, p.54), ou seja, à narrativa de Em busca do tempo perdido: sem o recurso das metonímias, a obra seria composta de uma mera sucessão de momentos líricos temporalmente não encadeados (não seria, portanto, um romance, mas um gigantesco poema). Para Laclau, "é o cruzamento de metáfora e metonímia que garante que exista uma narrativa" (Laclau, 2010, p.54). É como se dois eixos estivessem em jogo, explica o autor: um vertical, a metáfora, outro horizontal, a metonímia. No ponto de encontro entre eles é que se produziria a coerência - ou o efeito totalizador mencionado anteriormente. Sem a metonímia, a metáfora, por assim dizer, perde o chão. Essa interdependência aparece de modo mais evidente na maneira como a memória involuntária, as reminiscências, emergem de repente, no texto proustiano, como puras metáforas cujas origens só podem ser compreendidas diacronicamente de modo retrospectivo. É só de maneira retrospectiva que se torna possível reconhecer a origem metonímica que dá consistência à analogia que nos aparece, primeiramente, isolada de suas causas. A “verdadeira experiência”, nas palavras de Genette, não começa na compreensão de uma identidade de sensação entre a reminiscência e um objeto, um lugar, um tempo, mas num sentimento repentino de prazer ou felicidade (num afeto): "Essa primeira explosão é sempre acompanhada (...) necessariamente por uma reação em cadeia que procede, não por analogia, mas por contiguidade" (Genette apud Laclau, 2010, p.55). É nesse momento que se dá o contágio metonímico ou aquilo 
que Proust denomina "irradiação". É nesse ponto que ocorre a substituição metafórica. Há aí uma espécie de movimento pendular que vai da metáfora à metonímia e da metonímia de volta à metáfora para produzir a verdadeira experiência. É com base na compreensão desse mecanismo de interdependência que Laclau argumenta que:

pode-se dizer que a metáfora é o telos da metonímia, o momento em que a transgressão das regras de combinação alcança seu ponto de não retorno: uma nova entidade passa a existir e nos faz esquecer as práticas transgressivas nas quais se fundamenta. Mas sem essas práticas transgressivas, que são essencialmente metonímicas, uma nova entidade metafórica não teria emergido. Como mostra Genette, no caso de Proust, a analogia está sempre fundada numa contiguidade originária. (Laclau, 2010, p.62)

É nesse ponto que se torna possível se aproveitar - e é isso que Laclau parece fazer - da confusão instaurada entre discursivo e extradiscursivo para pensar a presença do extradiscursivo na operação hegemônica. Contiguidade significa adjacência, proximidade, vizinhança, remete a coisas que estão próximas no espaço. Nesse sentido, pela maneira como Laclau utiliza o conceito de metonímia e descreve sua passagem à metáfora, na obra de Proust, percebe-se que a articulação hegemônica, que ele associa à metáfora, depende de uma situação concreta. É preciso que exista contiguidade entre um conjunto de elementos. O corte populista, ou a relação hegemônica, não acontece ex nihilo. Para Laclau, contiguidade e analogia constituem dois polos de um contínuo. E isso aparece de maneira clara no exemplo que ele usa para ilustrar seu argumento, o de um bairro que, às voltas com casos de violência racial, encontra nos sindicatos da região a única força capaz de confrontar os grupos racistas. A princípio, combater o racismo não é um papel dos sindicatos. A assunção desse papel deriva de uma relação de contiguidade, de vizinhança. O que esse exemplo parece indicar é que é a contiguidade simbólica que possibilita ao sindicato representar, metonimicamente, a polícia. Mas não é uma contiguidade de ordem meramente simbólica ou conceitual. Ela nasce de uma contiguidade material relacionada às condições objetivas em que está inserida essa comunidade. Uma condição submete as pessoas dessa comunidade do exemplo a uma série de afetos cuja origem está diretamente relacionada aos encontros com o Real que a vida de uma pessoa negra, nesse tempo e espaço, proporciona. Parece que não precisamos recorrer aqui à ideia de uma plenitude impossível para compreender a escolha do 
sindicato como um objeto parcial. O que está em jogo, nesse exemplo, não parece ser "o seio" mítico, mas a sobrevivência mais imediata mesmo. É, como diria Espinosa, conatus: é o esforço para perseverar no ser.

Embora nesse exemplo a operação metonímica - ou hegemônica - seja reativa, pode-se perguntar se essa mesma lógica não pode ser acionada ativamente. Como se pode reconhecer ou, melhor ainda, como criar um milieu mais favorável à emergência de afetos que favoreçam, por sua vez, a articulação hegemônica? Como pensar a ação política em termos de misé-en-scène? Como pensá-la em termos de disposição de objetos num espaço para que os atores possam com eles interagir e atuar? E como pensar os limites dessa misé-en-sèene, também? Os limites impostos pelo próprio espaço em que os objetos são dispostos? O que se quer sugerir, com essas perguntas, é uma abordagem da política que remete, de certo modo, à proposta cosmopolítica de Isabelle Stengers (2005), tanto naquilo que ela extrai da química, quanto naquilo que ela extrai do conceito Chinês de manipulação.

Se você ler o maravilhoso livro de François Jullien, A Propensão das Coisas, vai descobrir uma arte da emergência que está muito próxima daquela da química. Jullien descreve a maneira pela qual os chineses veneram o que desprezamos: a manipulação, a arte da disposição que torna possível tirar vantagem da propensão das coisas, para "dobrá-las" de tal maneira que elas "espontaneamente" alcancem o que o artista, o homem de guerra ou o político querem. Longe de qualquer oposição entre submissão e liberdade: um pensamento focado na eficácia.

Poderia ser dito que esse é um estranho modelo para a política, mas essa sensação de estranhamento reflete nossa ideia de que a "boa" política tem que incorporar uma forma de emancipação universal: retire a alienação que dizem separar os seres humanos de sua liberdade e você obtém algo parecido com a democracia. A ideia de uma arte ou "técnica" política é portanto um anátema, um artefato separando os humanos de sua verdade. Referir-se à arte da química é afirmar que o agenciamento político não tem nada de espontâneo. O que chamamos democracia é ao mesmo tempo o caminho menos pior de manejar o rebanho humano e uma aposta focada na questão não do que os seres humanos são, mas do que eles podem ser capazes. É a questão que John Dewey colocou no centro de sua vida: como "favorecer", como "cultivar" hábitos democráticos? (Stengers, 2005, p.1001)

Em sua proposta cosmopolítica, Stengers chama atenção para o que denomina de perspectiva "ethoecológica", que afirma a inseparabilidade do ethos, a maneira peculiar de um ser se comportar, e o oikos, o habitat em que está inserido tal ser, "um habitat que satisfaz ou se opõe às demandas associadas ao ethos, ou oferece oportunidades para um ethos original se aventurar" (Stengers, 
2005, p.997). Inseparabilidade, para ela, não implica necessariamente em dependência.

Um ethos não é contingente em seu meio ambiente, se oikos; ele vai sempre pertencer ao ser que se prova capaz dele. Ele não pode ser transformado de nenhuma forma previsível. Mas nenhum ethos, em si mesmo, contém o próprio significado ou domina suas próprias razões. Nós nunca sabemos de que um ser é capaz ou do que pode ser capaz. Podemos dizer que o meio ambiente pressupõe, mas que o ser dispõe, dá ou se recusa a dar àquela proposta uma significação "etológica." (Stengers, 2005, p.997)

Manipular um espaço "etológico", entre o ethos e o oikos, para que novas possibilidades possam emergir, é, para Stengers (2005), algo da ordem da "magia", compreendida como a arte de desencadear eventos nos quais o que está em jogo é o empoderamento, no sentido de "tornar-se capaz de". É precisamente isso que determina, na magia, a eficácia de um ritual.

A eficácia de um ritual (...) não é a manifestação de uma divindade que poderia inspirar a resposta, mas aquela de uma presença que transforma as relações de cada protagonista com seu próprio conhecimento, suas próprias esperanças, medos $\mathrm{e}$ memórias, e permite ao todo produzir o que cada um era incapaz de produzir separadamente. A conquista do ritual pode ser chamada de "empoderamento", a produção de "partes" que não estão submetidas ao todo, mas devem à sua participação nesse todo seu poder para pensar e agir e resistir, o que não seriam capazes fazer sem ele. (Stengers, 2005, p.1002)

Essa concepção de magia parece ter ressonância naquela ilusão retrospectiva da nomeação, de que fala Laclau. A mágica do ritual também consiste em transformar "as relações de cada protagonista com seu próprio conhecimento, suas próprias esperanças, medos e memórias” (Stengers, 2005, p.1002), da mesma forma que a nomeação. Só que, de uma perspectiva "etológica" a mágica da significação, o sentido que permite transformar retrospectivamente seu ethos, só emerge numa relação com o oikos, com o meio.

A magia é uma arte de imanência radical, mas a imanência é precisamente aquilo que precisa ser engenhosamente criado, sendo o regime ordinário do pensamento aquele de uma transcendência que autoriza um ponto de vista e um julgamento. (Stengers, 2005, p.1002)

No próximo capítulo, essa dinâmica entre o ethos e o oikos poderá ser vislumbrada no processo de construção da hegemonia neoliberal. A hipótese de fundo é a de que a eficácia do neoliberalismo em impor-se como uma forma de 
racionalidade está relacionada tanto ao oikos configurado pelas mudanças estruturais do capitalismo, quanto à capacidade ritualística de criar espaços para que a subjetividade neoliberal - com seu homo oeconomicus, seu capital humano, seus empresários de si - pudesse emergir. 


\title{
3 \\ Crise ou mudança estrutural? Capitalismo democrático, razão neoliberal e desdemocratização
}

\author{
"Tinha de viver no meio do \\ incompreensivel, que é também \\ detestável. E há também o fascínio que \\ começa a se exercer sobre ele. $O$ \\ fascínio do abominável" \\ Joseph Conrad
}

A proposta deste terceiro capítulo é apresentar um conjunto de elementos que nos permitam contextualizar a questão da subjetividade contemporânea em sua relação com a razão neoliberal (Brown, 2015a; 2015b), e a relação da própria razão neoliberal com uma possível mudança estrutural do capitalismo. Entende-se que a produção de subjetividades, de uma perspectiva biopolítica, não pode prescindir de uma análise dessas relações, que obedeceriam a um princípio de causalidade imanente. Na medida em que traz de volta à cena a dinâmica entre infra e superestrutura, este capítulo representa um passo atrás em relação ao movimento empreendido pelo pós-marxismo, mas não uma recusa de conceitos como hegemonia e populismo, entre outros.

A estrutura do capítulo é um tanto quanto ziguezagueante. Tem como eixo a análise histórica do capitalismo democrático por Streeck (2012), que vai sendo complementada, gradualmente, pela abordagem de outros autores que permitem evidenciar uma série aspectos importantes para a compreensão da emergência de novas subjetividades em meio às "crises ou mudanças na armadura institucional do capitalismo (Lordon, 2015).

No subcapítulo 3.1, tem início uma tentativa de diagnóstico do contexto político-econômico contemporâneo, sobretudo a partir das transformações do capitalismo democrático, como entendido por Wolfgang Streeck (2012). A palavra "tentativa" é importante aí, pois um dos argumentos que será retomado ao final do capítulo é, precisamente, o de que a complexidade é uma das características do atual momento do capitalismo, o que torna virtualmente 
impossível qualquer representação totalizadora (o que, de certo modo, subscreve a ideia da irrepresentabilidade do Real, acionada por Laclau a partir de Lacan, no capítulo anterior).

No subcapítulo 3.2, é introduzido o conceito de biopolítica, para elucidar de que modo essas transformações do capitalismo poderiam ajudar a explicar certas expressões políticas da subjetividade contemporânea. No 3.3, essa discussão sobre biopolítica é aprofundada com base no processo de construção da hegemonia neoliberal, a partir de um complexo de discursos e práticas submetidos a uma racionalidade específica, sobretudo com base nas ideias desenvolvidas por Michel Foucault, em $O$ Nascimento da Biopolítica, e retomadas, recentemente, por Wendy Brown (2015a), para compreender o efeito desdemocratizador dessa racionalidade neoliberal, a partir dos seus impactos tanto sobre a ideia de cidadania quando sobre o ideal democrático. No subcapítulo 3.4, retoma-se a análise histórica de Streeck (2012) a fim de evidenciar o processo de complexificação da relações econômicas que nos conduziu ao momento atual e os reflexos dessa complexificação na política.

No subcapítulo 3.5, parte-se do conceito de escolha pública do processo que ficou conhecido como a tragédia dos comuns (Lloyd, 1833; Hardin, 1968), dois conceitos muito acionados pelo discurso neoliberal para defender a necessidade de impor limites ao exercício da soberania popular nas democracias, para em seguida rastrear-se o cerne desse discurso no pensamento de F.A. Hayek (1979). No subcapítulo seguinte, o 3.6, procura-se mostrar como o atual momento da razão neoliberal parece corroer as bases do discurso de Hayek sobre o estado mínimo como antídoto para a instrumentalização do poder coercitivo do Estado pelos grupos de interesse. Procura-se evidenciar, nesse ponto, de que modo a razão neoliberal, a disseminação do princípio da competição, a conversão do mercado num locus de verificação da verdade, entre outros aspectos daquilo que Foucault chamou de governamentalidade, parecem ter resultado, grosso modo, na subsunção do Estado (e da ideia mesma de democracia) ao mercado. A análise de Brown (2015b) permite, no final desse item, a transição para o tema da causalidade imanente e para a retomada da dinâmica entre infra e superestrutura, sob nova perspectiva, como forma de compreender o papel da imensa máquina capitalista na subjetividade contemporânea e reintroduzir a questão do afeto na discussão, agora em outros termos. 


\section{1}

\section{Crise do capitalismo democrático?}

O relatório de um estudo intergeracional divulgado pela Resolution Foundation, em 2016, revelou que, nos Estados Unidos e na Inglaterra, os chamados millenials ou Geração Y, a geração de pessoas nascidas a partir de 1981, eram os primeiros, desde que começaram tais estudos, a ganhar menos algo entre $15 \%$ e $20 \%$ menos - do que seus pais. De acordo com o relatório, a crise de 2008 teria apenas agravado a tendência que vinha sendo observada ao longo das últimas décadas, denotando um problema de ordem mais estrutural. O estudo parecia corroborar uma série de discussões que eclodiram, sobretudo nas economias desenvolvidas, na esteira da crise de 2008, desencadeada pelo estouro da bolha imobiliária norte-americana.

O tema foi abordado, por exemplo, por Thomas Piketty, em A Economia da Desigualdade (2015). Para o autor de O Capital do Século XXI, o aumento da desigualdade de renda oriunda do trabalho estava na base da inversão da Curva de Kuznets, que vinha ocorrendo desde os anos 1970. Nos Estados Unidos, aponta o autor, observou-se um aumento notável de cerca de 50\% na diferença salarial existente entre os $10 \%$ mais bem pagos e o restante dos assalariados (Piketty, 2015).

A Curva de Kuznets, também conhecida como "Hipótese do 'U’Invertido", foi desenvolvida pelo economista Simon Kuznets, em 1955, e descreve a relação entre renda e desenvolvimento econômico, observada em estudos empíricos realizados na Alemanha, na Inglaterra e nos Estados Unidos. A hipótese postula que a desigualdade de renda, nesses países, tendia a aumentar nos estágios iniciais de crescimento econômico até atingir um pico, a partir do qual começava a descer. Tal movimento, argumentava Kuznets, podia ser expresso graficamente na forma de um "U" invertido. Esse movimento econômico resultava, de acordo com o economista, da migração de trabalhadores de setores primários, mais atrasados tecnologicamente, para os centros urbanos, que concentravam os setores mais modernos da indústria, em áreas mais ricas, porém mais desiguais que aquelas constituídas em torno dos setores tradicionais. Esse movimento migratório, para Kuznets, seria uma característica intrínseca do crescimento econômico moderno, 
que obedeceria, via de regra, esse movimento de ascensão, apogeu e queda - ou aumento, estabilização e redução da desigualdade (Kuznets, 1955).

O que os estudos empíricos de Piketty apontam é que, sobretudo a partir dos anos 1970, o que se pode observar nas economias desenvolvidas é um retorno da desigualdade de renda, algo que, sobretudo no pós-guerra e no auge do fordismo, tinha caído significativamente. O período analisado por Pikkety corresponde exatamente ao que Wolfgang Streeck (2012) descreve como a era de ouro do capitalismo. Para o autor, tal período compreende, "nas porções 'ocidentais' do mundo, na América do Norte e na Europa Ocidental" (Streeck, 2012, p.36), aos trente glorieuses: as três décadas entre o final da Segunda Guerra Mundial meados dos anos $1970^{12}$.

A hipótese defendida por Streeck, como convém a um discípulo assumido da Escola de Frankfurt (que não seja Jürgen Habermas), não é das mais otimistas. O capitalismo democrático emerge de sua análise como um período de exceção, tanto no tempo quanto no espaço, dado o número limitado de países que desfrutaram dessa lua de mel entre democracia e capitalismo. Esse aspecto geográfico é importante porque nos permite, por exemplo, conceber essa análise do capitalismo democrático nos termos de um sistema-mundo, segundo a hipótese de Immanuel Wallerstein ${ }^{13}$ (2004). Esse aspecto do desenvolvimento capitalista, vale apontar, já era anunciado em 1966 por outro filho de Frankfurt, bem mais célebre que Streeck: Herbert Marcuse. No "Prefácio Político" escrito para uma

\footnotetext{
${ }^{12}$ Desse ponto em diante, argumenta Streeck, o crescimento da inflação, a queda nas taxas de lucro e a crise do petróleo, entre outros fatores macroeconômicos, teriam criado as condições para a ascensão das teorias neoliberais, que, posteriormente, se espalharam pelo resto do mundo, sob influência da Escola de Chicago e, mais tarde, por meio do conjunto de medidas que ficaram conhecidas como o Consenso de Washington, e foram disseminadas, na maior parte das assim chamadas democracias ocidentais - mas não só - com auxílio valioso do Banco Mundial e do Fundo Monetário Internacional.

${ }^{13} \mathrm{~A}$ análise do sistema-mundo exige que fenômenos econômicos, políticos, culturais e estruturas sociais, de maneira geral, sejam vistos de forma integrada, máquina composta de máquinas - uma megamáquina - mutuamente implicadas, num movimento sincrônico. Três aspectos são levados em conta por Wallerstein , numa perspectiva braudeliana de longue durée: a gênese da economiamundo capitalista, no século XVI; a gênese da geocultura liberal, na Revolução Francesa, em 1789; e o começo do fim daquilo que ele considera o estágio terminal desse modelo, em 1968. A globalização não é compreendida nessa análise como um fenômeno novo, mas como algo inerente à modernidade, algo que esteve presente desde seus primórdios, com o mercantilismo e as grandes navegações: "a realidade social em que vivemos e que determina quais são as nossas opções não têm sido os múltiplos estados nacionais dos quais somos cidadãos, mas uma coisa maior, que chamamos de sistema-mundo" (Wallerstein, 2004, p.X) e "esse sistema-mundo teve muitas instituições - estados e um sistema de interestados, firmas produtivas, donas de casa, classes, grupos identitários de todo tipo - e que essas instituições formam uma rede que permite ao sistema operar mas ao mesmo tempo estimula tanto os conflitos quanto as contradições que permeiam o sistema" (Wallerstein, 2004, p.X).
} 
das reedições de Eros e Civilização, o autor já chamava a atenção para o aspecto perverso dessa lua de mel entre capitalismo e democracia ou - para continuar no campo das metáforas lunares - para a "lua de fel" vivida pelo chamado Terceiro Mundo - a vasta maioria dos países que não se beneficiava tanto assim nem da democracia, nem do capitalismo, o que dirá dos dois juntos ${ }^{14}$.

O que a hipótese de Streeck indica é que o arranjo instável que garantiu a convivência pacífica entre capitalismo e democracia ruiu na década de 1970, deixando apenas o clima de desconfiança mútua que teria marcado, historicamente, a relação entre os dois ${ }^{15}$. Como aponta Streeck, estabeleceu-se, no pós-guerra, um consenso em torno da necessidade de controle político para que o capitalismo fosse compatível com a democracia - e para que "a própria democracia fosse protegida de restrições impostas pelo livre mercado (Streeck, 2012).

Vale pontuar aqui que, embora uma série de estudos importantes sobre o neoliberalismo - dentre eles O Nascimento da Biopolítica - situem as origens desse pensamento no período imediatamente posterior à crise de 1929 e vejam no Colóquio Walter Lippman, realizado na França, em 1938, um marco dessa ascensão do pensamento coletivo neoliberal, o fato é que a consolidação da rede de pensadores que exerceria um papel fundamental na disseminação dessas ideias e, posteriormente, na sua hegemonia, foi atrapalhada pela guerra e só depois dela tomou forma, principalmente após a constituição da Sociedade Mont Pèlerin (SMP), fundada por Friedrich von Hayek, em 1947, na Suíça. Essa característica do neoliberalismo, o movimento que antecede sua hegemonia, é um dos

\footnotetext{
${ }^{14}$ Questionando o próprio otimismo de anos antes, quando da primeira edição, Marcuse escrevia: "Não faz sentido falar sobre libertação a homens livres - e somos livres se não pertencemos à maioria oprimida. E não faz sentido falar sobre 'repressão excessiva' quando os homens e as mulheres desfrutam de mais liberdade sexual que nunca. Mas a verdade é que essa liberdade e satisfação estão transformando a Terra em inferno. Por enquanto, o inferno ainda está concentrado em certos lugares distantes: Vietnã, Congo, África do Sul, assim como nos guetos da "sociedades afluentes": no Mississipi, no Alabama, no Harlem. Esses lugares infernais iluminam o todo. É fácil e razoável ver neles apenas bolsões de pobreza e miséria numa sociedade em crescimento que é capaz de as eliminar gradualmente e sem catástrofe. A questão é: eliminadas a que preço - não em dólares e centavos, mas em vidas humanas e em liberdade?" (Marcuse n.d.)

15 "Suspeitas de que capitalismo e democracia possam não se combinar facilmente estão longe de ser novidade", ele argumenta. "Já no século XIX e em boa parte do século XX, a burguesia e a direita política manifestavam temores de que a 'regra da maioria', implicando, inevitavelmente, o predomínio dos pobres sobre os ricos, acabaria por extinguir a propriedade privada e os mercados livres. A classe trabalhadora ascendente e a esquerda política, por sua vez, advertiam que os capitalistas poderiam se aliar às forças reacionárias para abolir a democracia com o intuito de se protegerem de ser governados por uma maioria permanente empenhada na redistribuição econômica e social"'(Streeck, 2012).
} 
elementos que ajuda a corroborar a hipótese esboçada no capítulo anterior, que sinaliza para um processo de construção de um ambiente para o estabelecimento de determinadas relações (metonímicas) de contiguidade que funcionam como condição de possibilidade para a articulação hegemônica.

O período imediatamente posterior ao pós-guerra não se mostrou um dos mais favoráveis para o pensamento neoliberal. $\mathrm{Na}$ maior parte do mundo ocidental, o centro do palco econômico foi ocupado pelo keynesianismo, presente tanto nos modelos europeus welfare state quanto no New Deal de Roosevelt nos Estados Unidos. Tratava-se de um arranjo que pressupunha uma aceitação do mercado e da garantia da propriedade privada por parte das classes trabalhadoras, representadas pelos sindicados; classes trabalhadoras que receberiam, em troca, democracia política, seguridade social e melhorias constantes no padrão de vida por meio de aumentos salariais e mais acesso aos bens de consumo.

Nos anos 1960, no entanto, esse arranjo sofreu os primeiros abalos, quando o crescimento "começou a ratear", nas palavras de Streeck:

\begin{abstract}
Enquanto a livre negociação coletiva possibilitava aos trabalhadores, por meio de seus sindicatos, agir de acordo com expectativas, já firmemente arraigadas, de aumentos salariais anuais em caráter regular, o compromisso dos governos com o pleno emprego, bem como com a expansão do Estado de bem-estar, protegia os sindicatos de potenciais perdas de postos de trabalho causadas por acordos salariais que excediam o crescimento da produtividade. Desse modo, a política governamental alavancava o poder de barganha dos sindicatos para além do nível que um livre mercado de trabalho poderia sustentar. No final dos anos 1960 isso se traduziu em uma onda mundial de militância trabalhista, impulsionada por um vigoroso senso de direito político a um padrão de vida ascendente e livre do medo do desemprego. (Streeck, 2012, p.40)
\end{abstract}

Para David Harvey (2014), a crise dos anos 1970, que combinou aumento do desemprego com alta da inflação, pode ser descrita como uma crise da acumulação do capital. Para o teórico marxista, a aliança entre trabalho representado por sindicatos fortes - e movimentos sociais urbanos parecia criar condições para a emergência de uma "alternativa socialista ao compromisso social entre capital e trabalho, que fundamentara com tanto sucesso a acumulação do capital no pós-guerra" (Harvey, 2014, p.24). O crescimento de partidos de esquerda na Europa e a pressão de movimentos populares por reformas, nos Estados Unidos, apontavam nessa direção, mas por todo lado havia indicações 
nesse sentido. ${ }^{16} \mathrm{O}$ maior desafio às elites capitalistas, no entanto, era representado, em termos marxianos, pela redução da taxa de lucro, dificuldade crescente para a extração de mais-valor, graças, por um lado, à força dos sindicatos à época e, por outro, ao pavor que os governantes tinham desenvolvido em relação ao desemprego durante a era de ouro do capitalismo democrático: para a maioria dos políticos, nas economias avançadas, o desemprego era visto como uma ameaça não apenas à sua sobrevivência política - à sua popularidade, à sua capacidade de angariar votos e se manter no poder - mas à "estabilidade da própria democracia capitalista" (Streeck, 2012).

Num primeiro momento, esse conjunto de fatores produziu o que Streeck descreve como "uma política monetária acomodatícia", que tinha como objetivo preservar o equilíbrio entre negociação coletiva e pleno emprego, ainda que isso implicasse num aumento crescente da inflação. Esse arranjo, é claro, não se sustentou por muito tempo. Embora não representasse, a princípio, "um grande problema para trabalhadores representados por sindicatos fortes e com poder político suficiente para obter indexação salarial de facto" (Streeck, 2012, p.41), a inflação afetava significativamente os credores e detentores de ativos financeiros, uma parcela da população que, pelo menos nos anos 1960 e 1970, não incluía os trabalhadores. Nesse sentido, a inflação aparecia como reflexo monetário de um conflito distributivo entre os trabalhadores que pressionavam por garantia de emprego e maior participação na renda, enfatizando os aspectos democráticos da cidadania, e uma classe capitalista que queria maximizar o retorno sobre seu capital, tentando fazer valer o direito privado e a soberania do mercado. Há indícios de que esse conflito entre capital e trabalho, no âmbito da democracia capitalista, poderia ser considerado estruturalmente inerradicáve ${ }^{17}$ : o crescimento econômico do pós-guerra, sobretudo em seus anos iniciais, é que teria

\footnotetext{
16 "Havia nisso uma clara ameaça politica às elites econômicas e classes dirigentes em toda parte, tanto em países capitalistas avançados (como a Itália, a França, a Espanha e Portugal) como em muitos países em desenvolvimento (como o Chile, o México e a Argentina). Na Suécia, por exemplo, o que ficou conhecido como o Plano Rehn-Meidner, se ofereceu literalmente para comprar gradualmente a parcela dos proprietários em seus próprios negócios e transformar o país numa democracia de trabalhadores/acionistas" (Harvey, 2014, p.24-5).

${ }^{17}$ Para Streeck, ainda: "a inflação também pode ser considerada uma expressão de anomia numa sociedade que, por razões estruturais, não consegue chegar a um critério comum de justiça social. Foi nesse sentido que o sociólogo britânico John Goldthorpe sugeriu, no final dos anos 1970, que a inflação alta era inerradicável numa economia de mercado capitalista democrática que permitia que trabalhadores e cidadãos corrigissem efeitos negativos dos mercados mediante ação política coletiva (Streeck, 2012, p.41).
} 
possibilitado aos governos adiar o choque entre as duas dimensões, disponibilizando bens e serviços à população, ou seja, as bênçãos do estado de bem-estar. Com a queda do crescimento econômico, "os governos tinham de se virar com dinheiro adicional, ainda não chancelado pela economia real, como um meio de antecipar recursos futuros através do consumo e da distribuição no presente" (Streeck, 2012, p.41). Em outras palavras, dívida. E foi precisamente nesse contexto que as ideias neoliberais passaram a ganhar espaço na formulação das políticas macroeconômicas, afinal,

como Hayek nunca cansava de assinalar, inflação acelerada fatalmente ocasiona distorções econômicas que, num determinado ponto, tornam incontroláveis os preços relativos, a relação entre rendas variáveis e fixas e aquilo que os economistas chamam de "incentivos econômicos". Ao provocar reações kaleckianas de detentores de capitais cada vez mais desconfiados, a inflação acaba por gerar desemprego, penalizando os mesmos trabalhadores cujos interesses ela poderia, inicialmente, favorecer. A essa altura, no mais tardar, os governos, sob o capitalismo democrático, sofrerão pressões para abandonar os arranjos salariais redistributivo-acomodatícios e restituir a disciplina monetária. (Streeck, 2012, 39)

Foi precisamente nessa direção que grande parte dos governos dos países desenvolvidos começou a caminhar em meados da década de 1970. Não parece obra do acaso que o período que tem início aí corresponda, precisamente, ao começo da inversão na Curva de Kuznets investigada por Piketty. Desde então, o que se observa é uma interrupção do movimento de redução das desigualdades, observado ao longo dos trente glorieuses. Essa mesma tendência é identificada por Harvey (2014), que observa que, nos Estados Unidos a parcela da renda nacional na mão do $1 \%$ mais rico caiu de $16 \%$, antes da Segunda Guerra, para $8 \%$, depois dela, tendo se mantido neste patamar exatamente por três décadas, quando, finalmente, "sofreu uma acentuada queda com o colapso do valor dos ativos (ações, imóveis, poupanças)" (Harvey, 2014, p.25). Era às perdas desse grupo que Streeck se referia, em trecho supracitado, ao falar que a inflação afetava de sobremaneira os credores e detentores de ativos financeiros, o mesmo grupo que pressionou os governos pela restituição da disciplina monetária ${ }^{18}$. A abordagem

\footnotetext{
${ }^{18}$ Uma forma de compreender como se deu, em termos práticos, essa pressão em cima dos governos, seja atentando para as relações entre o mundo financeiro e os think tanks neoliberais. Em seu estudo sobre a Sociedade Mont Pèlerin, Mirowski e Plehwe dão bastante destaque à importância do financiamento do primeiro encontro da Sociedade, em 1947, e à importância desse apoio para a garantia do caráter internacionalista e para a capilarização do pensamento coletivo neoliberal. "A visão internacionalista e o esforço organizacional só foi possível graças a um providencial apoio corporativo/institucional. The Foundation for Economic Education, em
} 
de Harvey é bem mais incisiva quanto a isso. Para ele, esse cenário produziu um contra-ataque imediato da elite: "As classes ricas tinham que agir com mais vigor para se proteger da aniquilação política e econômica” (Harvey, 2014, p.25).

Esse movimento descrito por Streeck também pode ser identificado, como aponta Fréderic Lordon (2015), na obra de economistas vinculados à chamada Teoria da Regulação ${ }^{19}$. Para Lordon, a palavra "crise" não faria feio num “concurso dos conceitos mais mal construídos" (Lordon, 2015, p.89). Para ele, uma grande contribuição da teoria da regulação, que surgiu precisamente após a "crise" dos anos 1970, à economia foi conceber o que os economistas neoclássicos e keynesianos chamavam de "crise" como um reflexo de mudanças estruturais do capitalismo.

Inspirada pela historicização dialética herdada do marxismo, a teoria da Regulação teve, então, como primeiro movimento, romper com o universalismo transhistórico (ou, antes, a-histórico) das "leis da economia", afim de pensar a acumulação do capital em suas sequências particulares, isto é, como processo periodizado. Ainda era preciso, nesse processo, abandonar a imagem originária da economia como "sistema de mercados" e tomar por objeto alternativo o capitalismo, desde então concebido como conjunto de relações sociais institucionalmente aparelhadas, e cumprir a ideia de que, se o capitalismo só se faz ver em suas configurações institucionais, logo, ele está constitutivamente sujeito a transformações históricas (assim como geográficas). (Lordon, 2015, p.92)

O que a Teoria da Regulação aponta é que o capitalismo muda porque mudam suas "armaduras institucionais" (Lordon 2015, 92). As relações sociais, debaixo do capitalismo, no seu entender, seriam invariantes de longo período. As instituições que as exprimem é que seriam, elas sim, produtos da história "e, como tais, contingentes e temporárias, passíveis de formação e transformação pela história" (Lordon, 2015, p.92). Essas mudanças institucionais, essas

Irvington-on-Hudson, Nova York, que empregava Ludwig von Mises e o William Volker Fund, de Kansas City, providenciaram subsídios. The Volker Fund, que mais tarde seria liderado por Harold Luhnow, futuro membro da SMP, providenciou os recursos para a viagem dos participantes provenientes dos Estados Unidos. The Schweizerische Kreditanstalt (hoje conhecido como Credit Suisse), cobriu 93\% do custo total da conferência - 18.062,08 francos suíços" (Mirowski e Plehwe, 2009, p.15). Outro aspectos que os autores destacam, é que a rede formada em torno da Sociedade sempre esteve mais próxima de banqueiros que de empresários, que nela estavam representados em número reduzidíssimo, pois havia, por parte dos intelectuais, uma grande suspeita em relação ao "(...) pragmatismo oportunista das lideranças empresariais do pós-guerra" (Mirowski e Plehwe, 2009, p.6). Para os neoliberais, dizem os autores, o empresariado precisava ser reeducado para livrar-se dos hábitos corporativistas e da mania de planejamento. De certo modo, desde suas origens, o pensamento coletivo neoliberal sempre privilegiou os "credores e detentores de ativos financeiros".

${ }^{19}$ Ainda Segundo Lordon, por trás das obras fundadoras dessa escola econômica encontram-se nomes como Aglieta, Boyer e Mistral. 
transformações históricas do capitalismo explicariam as diferenças, por exemplo, na relação assalariada durante os trente glorieuses e as atuais, sob a hegemonia neoliberal. $\mathrm{O}$ mesmo se pode aplicar às diferenças observáveis no modelo de concorrência/competição - bancário-financeira, industrial e estatal - sob uma ou outra armadura institucional. A teoria da Regulação, argumenta o autor, “dá certa consistência analítica a essa intuição elementar, porém correta, de que o capitalismo varia" (Lordon, 2015, p.92). Mudam formas institucionais, mudam mecanismos de acumulação e mudam os caminhos do crescimento, as taxas de desemprego - e a desigualdade. O capitalismo, para ele, se mostra na sucessão dos diferentes regimes de acumulação e "chamamos de 'crise' a transição de uma dessas 'épocas' à outra” (Lordon, 2015, p.93). Como aponta Lordon, o regime de acumulação fordista, que prevaleceu nos trente glorieuses, investigados por Streeck, consistia na extração de ganhos de produtividade por meio da aceleração do ritmo da produção em série, que chegava ao limite com a saturação do mercado interno, inundado de produtos baratos. Passava-se, dessa forma, da demanda inicial por equipamentos para uma demanda de renovação desses equipamentos, desta vez mais curta e diferenciada, o que exigia, em seguida, mudanças nas formas de organização da produção industrial que perturbavam seu regime de produtividade.

\begin{abstract}
Buscar prolongar a lógica fordista das séries longas por substituição das exportações pelo consumo interno só faz aumentar a desestabilização do regime cujo fechamento macroeconômico reside na progressão forte e regular dos salários, virtuosa em um esquema de crescimento autocentrado, no qual a dissolução do consumo interno é decisiva, porém, considerada equivocadamente, visto que a economia se abre para além de certa fronteira e se encontra engajada no jogo da competitividade pelos custos. Em uma ilustração típica da dialética marxiana, o fordismo morre, então, por ter sido bem-sucedido, e é o próprio funcionamento de sua estrutura que, no longo prazo, "entortou" essa estrutura, até levar ao ponto crítico, no qual se rompe a coerência antiga. (Lordon, 2015, p.93)
\end{abstract}

O que se pode depreender dessa análise é que a hegemonia do pensamento coletivo neoliberal não surge, por assim dizer, out of the blue. $\mathrm{O}$ senso de oportunidade, observado pelos teóricos neoliberais, é digno de nota. É digno, em verdade, de livro, como bem percebeu Naomi Klein (2008), pois é precisamente nisso que consiste a doutrina do choque, descrita por ela em livro homônimo. Para essa autora, os ideólogos do neoliberalismo teriam um faro aguçado para as "crises" ou, como prefere Lordon, para os sinais de mudança estrutural no 
capitalismo. Tal senso de oportunidade não serve apenas na entrega de partes do Estado à iniciativa privada, num processo que David Harvey (2014) chamou de acumulação por espoliação, numa compreensão cíclica do processo da "assim chamada acumulação primitiva", descrito por Marx, algo que já tinha sido esboçado por Hannah Arendt e Rosa Luxemburgo, cuja ideia básica é de que a privatização das terras comuns que marcou a passagem do modelo feudal para o capitalista ao promover o encontro entre o capital (dos donos dos meios de produção) e o trabalho livre (dos camponeses destituídos de terra e de meios para a realização de seu trabalho e preservação de sua existência) não foi um episódio isolado, mas é algo que se repete historicamente. A doutrina do choque serve, obviamente, para isso também. Mas serve, sobretudo, como janela para intervir na armadura institucional do capitalismo para, por meio dela, exercer uma espécie de soft power. Em linhas gerais, é isso que está em jogo no conceito de biopolítica, na obra de Michel Foucault.

\section{2 \\ Biopolítica e razão neoliberal}

Para Michel Foucault (2008), o biopoder está vinculado ao conceito de governamentalidade, um poder que consiste numa tecnologia, uma forma de racionalidade, uma arte de governar que age sobre os corpos de maneira indireta, intervindo positivamente no espaço onde estão inseridos tais corpos, por meio de leis, medidas, regulamentações, todo repertório de táticas materializadas num conjunto de instituições, práticas e formas de pensamento que têm como alvo a população, a economia-política aí constituída como um locus de verificação da verdade - e tem os dispositivos de segurança utilizados como instrumentos. Foucault termina uma de suas famosas aulas no College de France, em 11 de janeiro de 1978, com uma referência à biopolítica que é bastante esclarecedora. Ele diz:

Para terminar, remeterei simplesmente a um texto daquele que foi sem dúvida o primeiro grande teórico do que poderíamos chamar de biopolítica, de biopoder. Ele fala disso, aliás, a respeito de outra coisa, a natalidade, que foi evidentemente um dos grandes desafios, mas vê-se muito bem surgir aí a noção de um meio históriconatural como alvo de uma intervenção de poder, que me parece totalmente diferente da noção jurídica de soberania e de território, diferente também do espaço disciplinar. [É a propósito dessa] ideia de um meio artificial e natural, em que o 
artifício age como uma natureza em relação a uma população que, embora tramada por relações sociais e políticas, também funciona como uma espécie, que encontramos nos Estudos sobre a população de Moheau um texto como este: "Depende do governo mudar a temperatura do ar e melhorar o clima; um curso dado às águas estagnadas, florestas plantadas ou queimadas, montanhas destruídas pelo tempo ou pelo cultivo contínuo da superfície formam um solo e um clima novos. Tamanho é o efeito do tempo, da habitação da terra e das vicissitudes da ordem física, que os cantões mais sadios tornaram-se morbígenos". Ele se refere a um verso de Virgílio em que se fala do vinho que gela nos tonéis e diz: será que veríamos hoje, na Itália, o vinho gelar nos tonéis. Pois bem, se houve tanta mudança, não é que o clima mudou, é que as intervenções políticas e econômicas do governo modificaram o curso das coisas a tal ponto que a própria natureza constituiu para o homem, eu ia dizendo, um outro meio, só que a palavra "meio" não está em Moheau. Em conclusão, ele diz: "Se do clima, do regime, dos usos, do costume, de certas ações resulta o princípio desconhecido que forma o caráter e os espiritos, pode-se dizer que os soberanos, por leis sábias, por instituições sutis, pelo incômodo que trazem os impostos, pela consequente faculdade de suprimi-los, enfim, por seu exemplo, regem a existência física e moral dos seus súditos. Talvez um dia seja possivel tirar partido desses meios para matizar à vontade os costumes e o espirito da nação". Como vocês estão vendo, voltamos a encontrar aqui o problema do soberano, mas dessa vez o soberano não é mais aquele que exerce seu poder sobre um território a partir de uma localização geográfica de sua soberania política, o soberano é algo que se relaciona com uma natureza, ou antes, com a interferência, a intricação perpétua de um meio geográfico, climático, físico com a espécie humana, na medida em que ela tem um corpo e uma alma, uma existência física e moral; e o soberano será aquele que deverá exercer seu poder nesse ponto de articulação em que a natureza no sentido dos elementos fisicos vem interferir com a natureza no sentido da natureza da espécie humana, nesse ponto de articulação em que o meio se torna determinante na natureza. É aí que o soberano vai intervir e, se ele quiser mudar a espécie humana, só poderá fazê-lo, diz Moheau, agindo sobre o meio. Creio que temos aí um dos eixos, um dos elementos fundamentais nessa implantação dos mecanismos de segurança, isto é, o aparecimento, não ainda de uma noção de meio, mas de um projeto, de uma técnica política que se dirigia ao meio" (Foucault, 2008b, p.29-30).

O biopoder, para Foucault, não é exercido diretamente ou exclusivamente pelo Estado, que não possui para o filósofo francês "esta unidade, essa individualidade, essa funcionalidade rigorosa” (Foucault, 1979, p.292) - nem tampouco essa importância ${ }^{20}$. No capítulo final de Vontade de Saber, o primeiro volume da História da Sexualidade, Foucault avança nessa definição do biopoder, agora apontando sua íntima relação com o capitalismo e na transformação que ele impôs ao mundo do trabalho.

Este biopoder, sem dúvida, foi elemento indispensável ao desenvolvimento do capitalismo, que só pode ser garantido à custa da inserção controlada dos corpos no aparelho de produção e por meio de um ajustamento dos fenômenos de população aos processos econômicos. Mas o capitalismo exigiu mais do que isso; foi-lhe

\footnotetext{
${ }^{20}$ Para ele: “(...) o Estado não é nada mais que uma realidade compósita e uma abstração mistificada, cuja importância é muito menor do que se acredita.” (Foucault, 1979, p.292)
} 
necessário o crescimento tanto de seu reforço quanto de sua utilizabilidade e sua docilidade; foram-lhe necessários métodos de poder capaz de majorar as forças, as aptidões, a vida em geral, sem por isto torná-las mais difíceis de sujeitar. Se o desenvolvimento dos grandes aparelhos de Estado, como instituições de poder, garantiu a manutenção das relações de produção, os rudimentos de anátomo e biopolítica, inventados no século XVIII como técnicas de poder presentes em todos os níveis do corpo social e utilizadas por instituições bem diversas (a família, o exército, a escola, a polícia, a medicina individual ou a administração das coletividades), agiram no nível dos processos econômicos, do seu desenrolar, das forças que estão em ação em tais processos e os sustentam; operaram, também, como fatores de segregação e hierarquização social, agindo sobre as forças respectivas tanto de uns como de outros, garantindo relações de dominação e efeitos de hegemonia; o ajustamento da acumulação dos homens à do capital, a articulação do crescimento dos grupos humanos à expansão das forças produtivas e a repartição diferencial do lucro, foram, em parte, tornados possíveis pelo exercício do biopoder com suas formas e procedimentos múltiplos. O investimento sobre o corpo vivo, sua valorização e a gestão distributiva de suas forças foram indispensáveis naquele momento. (Foucault, 1988, p.153-4)

O biopoder operou, na passagem para o capitalismo, na produção dos corpos dóceis e utilizáveis que seriam consumidos na indústria nascente. Operou para produzir o encontro entre o trabalhador livre, cuja única posse era sua própria força de trabalho, e o capitalista, dono dos meios de produção, num processo descrito em detalhes por Marx (2013), no capítulo de $O$ Capital dedicado à “assim chamada acumulação primitiva". E operou, também, na organização do trabalho na fábrica.

É Pierre Macherey (2015) quem chama atenção para a importância dessa intersecção entre a concepção biopolítica do poder em Foucault e Marx. Em um artigo publicado em outubro de 2015 na revista eletrônica Viewpoint Magazine, Macherey recupera uma palestra proferida por Foucault na Bahia, em $1976^{21}$, na qual o francês afirma que essa concepção positiva do poder só pode ser encontrada em dois pensadores: Bentham e Marx. (Neste último, especialmente no capítulo que trata da produção do mais-valor relativo). Para Foucault, ambos falam da emergência de uma nova configuração do poder que coincide com a ascensão do capitalismo e da burguesia, mas não corresponde, no entanto, a uma tomada do poder político, pois depende apenas do manejo das forças da vida por meio da economia (Macherey, 2015).

Para Macherey, essa interpretação vai ao encontro do conceito de determinação em última instância pela economia, com a condição de que "seja estendido para eventualmente subsumir o gerenciamento da 'produção' (para 
seguir o termo o ambíguo de Foucault) da vida em todas as suas formas" (Macherey, 2015). Foucault enumera quatro dimensões que caracterizariam essa transformação do poder, sempre se referindo a Marx: sua dispersão numa multiplicidade de poderes heterogêneos; seu desvinculamento da forma-estado; sua orientação positiva, em vez de proibitiva ou repressiva; e a tecnicização não planejada, baseada em tentativa e erro e não subordinada a um telos preconcebido (Macherey, 2015). Macherey destaca que para Foucault esse último ponto é o mais importante e encontra-se sintetizado no trecho supracitado de $A$ Vontade de Saber.

Com o neoliberalismo, o que se vê é a biopolítica emergir como uma técnica de governo privilegiada, que consiste em organizar, administrar, gerir instituições e instituir práticas ${ }^{22}$ capazes de produzir subjetividades concebidas em termos de capital humano. O neoliberalismo não consiste apenas em mais uma forma de espoliar o Estado, como denuncia, por exemplo, David Harvey. O neoliberalismo é uma forma de apoderar-se de corações e mentes, como bem sabia Margaret Thatcher. Para tanto, ele não intervém apenas no nível das palavras e imagens: o discurso neoliberal sempre está sedimentado em práticas e instituições. Em $O$ Nascimento da Biopolitica, Foucault (2008) articula e aplica uma série de conceitos que vinha desenvolvendo ao longo dos anos para pensar a ascensão do neoliberalismo. A produção dos corpos dóceis, os dispositivos, a relação saberpoder, tudo isso entra, de alguma forma, nessa tentativa de compreender a relação entre o neoliberalismo e a biopolítica.

O que o uso biopolítico de práticas e instituições pelos teóricos do neoliberalismo analisados por Foucault parece demonstrar é que os afetos, que se encontram na base do investimento radical, tão importantes no processo de construção de identidades políticas concebido por Laclau, não são apenas instrumentalizáveis, mas passíveis de serem produzidos e reproduzidos. Dessa perspectiva, não fica muito difícil compreender a força do discurso neoliberal e a resiliência dessa hegemonia.

Que tipo de práticas e instituições essa razão neoliberal engendra? Qual a armadura institucional do capitalismo em sua forma neoliberal? Em que ela difere

\footnotetext{
${ }^{22}$ Um dos modos preferidos de intervenção neoliberal em empresas, escolas, universidades ou mesmo Ong's é, por sinal, através da disseminação de "melhores práticas". (Brown, 2015; Dardot e Laval, 2016)
} 
das outras? O que a distingue de sua forma liberal? Que tipo de afecções o neoliberalismo produz? Que tipo de subjetividade pode emergir desse ambiente modelado pela racionalidade neoliberal?

Para Wendy Brown (2015b), que articula sua crítica da razão neoliberal, e da ameaça que ela representa para a democracia, sobretudo a partir dos estudos de Foucault (2008), o neoliberalismo "transforma de maneira grotesca todo domínio e empreendimento humanos, juntamente com os próprios seres humanos, de acordo com uma imagem específica do econômico" (Brown, 2015b, p.10). No caso do neoliberalismo, essa imagem baseia-se, acima de tudo, no princípio da concorrência. Para Foucault (2008), essa centralidade conferida à concorrência é uma das principais distinções que se pode estabelecer entre o neoliberalismo e o liberalismo clássico, cujo protagonismo era do mercado - compreendido por Adam Smith como resultado natural da propensão humana à barganha, à troca $\mathrm{e}$ aos negócios. O mercado era concebido pelos liberais de maneira naturalista, como um sistema dotado de uma racionalidade própria, que para funcionar precisava apenas ser deixado em paz. Feito isso, a felicidade humana adviria, também ela, naturalmente, por obra e graça da mão invisível do mercado, que se encarregaria coordenar, por meio de sua dinâmica interna, regida por uma lógica imanente, a distribuição de bens e serviços da maneira mais justa e eficaz.

Para os liberais, como aponta Foucault, o mercado, domínio da propriedade e da iniciativa privada que devia ser garantido e preservado incondicionalmente, se opunha ao Estado. Em sua análise do liberalismo, como aponta Jason Read (2009), Foucault se interessa sobretudo em compreender a maneira como o mercado deixa de ser aí compreendido como mera instituição ou prática para converter-se no fundamento para uma crítica do poder estatal. "O liberalismo clássico faz da troca a matriz geral da sociedade" (Read, 2009, p.27). Por meio dele se estabelece uma homologia entre a liberdade nas relações mercantis e a liberdade civil.

Seguindo essa linha de raciocínio, é possível conectar essa caracterização do liberalismo clássico ao conceito de paradoxo democrático (Mouffe, 2000), apresentado aqui no segundo capítulo. É possível dizer que a genealogia da faceta liberal (os princípios da liberdade individual e dos direitos humanos universais), nesse arranjo paradoxal que Mouffe identifica na base da democracia moderna, tem origem nessa homologia entre livre mercado e liberdades civis descrita por 
Foucault (2008). O neoliberalismo, no entanto, altera significativamente esse arranjo, como se pode depreender das análises de Wendy Brown sobre o processo de desdemocratização como resultado da razão neoliberal.

\section{3 Neoliberalismo e desdemocratização}

Se o liberalismo clássico baseava sua concepção do mercado na ideia de troca e defendia o princípio do laissez-faire, os ordoliberais e neoliberais fizeram da concorrência um valor supremo e viam na concepção clássica de laissez-faire um resquício de naturalismo, contra o qual se rebelavam: a concorrência não é, para eles, algo natural, que decorre do jogo de apetites, instintos e comportamentos humanos, mas resulta de um princípio formal ${ }^{23}$. Para Foucault,

\footnotetext{
${ }^{23}$ Como aponta Foucault, o ordoliberalismo surgiu como técnica de governo na Alemanha esfacelada do pós-guerra, um país ocupado, às voltas com uma crise de legitimidade jurídica, incapaz de estabelecer um consenso que manifestasse uma vontade coletiva e, diante do desastre do nazismo, desprovida de direitos históricos capazes de fundamentar um Estado. $\mathrm{O}$ que o ordoliberalismo ofereceu foi a possibilidade de fazer da economia esse fundamento. Esse arranjo cumpriu, no contexto alemão da época, uma função tática: a legitimidade, que não podia se amparar nem no direito constitucional, apoiou-se no regime econômico. Ao assegurar liberdade econômica antes de um aparelho estatal, os economistas alemães que integravam o Conselho Científico para a administração da economia na "bizona", formada pelos territórios alemães então ocupados por ingleses e americanos, garantia "aos diferentes lobbies americanos a certeza de que poderiam ter com essa indústria e com essa economia alemãs as livres relações que quisessem escolher" (Foucault, 2008, p.109). Por outro lado, esse arranjo tranquilizava a Europa, assegurando-a de que tal embrião institucional que aí se formava não ofereceria os mesmos perigos do Estado forte (e totalitário) que o continente experimentara anos antes. "Na Alemanha contemporânea, de 1948 até hoje, isto é, durante trinta anos, não se deve considerar que a atividade econômica foi apenas um dos ramos da atividade da nação. Não se deve considerar que a boa gestão econômica não teve outro efeito e nenhum outro fim previsto e calculado senão o de assegurar a prosperidade de todos e de cada um. Na verdade, na Alemanha contemporânea, a economia, o desenvolvimento econômico, o crescimento econômico produz soberania, produz soberania política pela instituição e pelo jogo institucional que faz precisamente funcionar essa economia. A economia produz legitimidade para o Estado, que é seu avalista. Em outras palavras e é esse um fenômeno importantíssimo, que sem dúvida não é um único na história, mas mesmo assim é muito singular, pelo menos na nossa época -, a economia é criadora de direito público. Temos, perpetuamente, na Alemanha contemporânea, um círculo que vai da instituição econômica ao Estado; e embora, claro, exista um circuito inverso, que vai do Estado à instituição econômica, não se deve esquecer que o primeiro elemento dessa espécie de sifão está na instituição econômica. Gênese, genealogia permanente do Estado a partir da instituição econômica. E quando digo isso, creio que ainda não basta, porque não é apenas uma estrutura jurídica ou uma legitimação do direito que a economia traz a um estado alemão que a história acaba de privar de seus direitos. Essa instituição econômica, a liberdade econômica que essa instituição tem por papel, desde o início, assegurar e manter, produz algo mais real, mais concreto, mais imediato ainda, que é uma legitimação de direito. Ela produz um consenso permanente, um consenso permanente de todos os que podem aparecer como agentes no interior desses processos econômicos. Agentes como investidores, agentes como sindicatos. Todos esses parceiros da
} 
esse formalismo se manifesta num estilo de governo altamente intervencionista, que embora rejeite a interferência direta no mercado exige interferência constante nos elementos formais da economia. Em outras palavras, o neoliberalismo age nas regras do jogo: na moldura institucional ${ }^{24}$. Biopoliticamente, age sobre a legislação (criando e modificando leis), sobre o território (promovendo deslocamentos geográficos de populações, infraestruturas, redirecionando fluxos de capital), e sobre a formação das pessoas (capacitando capital humano, introduzindo novas tecnologias, regulando taxas de juro e fixando metas de inflação etc.).

Já para Wendy Brown (2015a), que rejeita, em termos práticos, a distinção foucaultiana entre ordoliberalismo e neoliberalismo:

[e]mbora coloque o mercado em primeiro plano, a racionalidade neoliberal não está nem exclusivamente nem prioritariamente focada na economia; ela envolve estender e disseminar os valores do mercado para todas as instituições e atividades sociais. (Brown 2015a, 39-40)

Para a autora, o efeito desdemocratizador do neoliberalismo reside precisamente nisso: é uma consequência da submissão de todas as dimensões da existência humana a uma racionalidade econômica orientada pelo princípio da concorrência, que faz com que toda ação passe a ser submetida a um cálculo por meio do qual seu valor (sua utilidade, os benefícios e o grau de satisfação que ela produz) se mede exclusivamente em termos de escassez, oferta e demanda. "O neoliberalismo não simplesmente assume que todos os aspectos da vida social, cultural e política podem ser reduzidos a tal cálculo”, defende Brown (2015a, p.40), mas cria diversos mecanismos para recompensar, estimular e reforçar esse

economia, na medida mesma em que aceitam esse jogo econômico da liberdade, produzem um consenso que é um consenso político. (Foucault, 2008, p.114-5)

\footnotetext{
24 "As boas intervenções vão agir sobre o quê? Pois bem, sobre a moldura. Isto é, em primeiro lugar, sobre a população. A população agrícola é numerosa demais - pois então será preciso diminuí-la por meio de intervenções que possibilitem transferências de população, que possibilitem uma migração etc. Será preciso intervir nas técnicas, pondo à disposição das pessoas certo número de ferramentas, pelo aperfeiçoamento técnico de certo número de elementos relacionados aos adubos etc.; intervir sobre a técnica também pela formação dos agricultores e pelo ensino que lhes será proporcionado, que lhes possibilitará modificar de fato as técnicas [agrícolas]. Em terceiro lugar, modificar também o regime jurídico das terras, em particular com leis sobre a herança, com leis sobre o arrendamento das terras, tentar encontrar os meios de fazer intervir a legislação, as estruturas, a instituição de sociedades por ação na agricultura etc. Em quarto lugar, modificar na medida do possível a alocação dos solos e a extensão, a natureza e a exploração dos solos disponíveis. Enfim, no limite, é preciso intervir sobre o clima." (Foucault, 2008, p.192-3)
} 
comportamento, graças, precisamente, ao caráter normativo identificado por Foucault: "o neoliberalismo produz atores racionais e impõe uma racionalidade de mercado para a tomada de decisão em todas as esferas" (Brown, 2015a, p.40). Produz, em outras palavras, a subjetividade necessária para seu bom funcionamento: o neoliberalismo é, para ela, nesse sentido, "um projeto construtivista" (Brown, 2015a, p.40). Na mesma linha, pode-se dizer também, a partir de Laclau, que o liberalismo é um projeto hegemônico, na medida em que se estrutura em torno de um corte que institui uma oposição entre os indivíduos atomizados - os empresários de si - e o estado paternalista/assistencialista, com seus grupos de interesse, suas políticas assistenciais, seus sindicatos, etc. $\mathrm{Ou}$ mesmo o bom e velho socialismo/comunismo, que Hayek e Mises, dois expoentes da Escola Austríaca, identificavam em toda tentativa de controle ou regulação da economia. É nesse sentido que se pode falar de um pensamento coletivo neoliberal (Mirowski e Plehwe, 2009). A biopolítica, que vinha se consolidando como arte de governar, encontra no pensamento dos teóricos do neoliberalismo, por assim dizer, uma forma e, nos significantes mobilizados, a força necessária para dividir a sociedade em dois campos antagônicos: de um lado, os indivíduos; de outro a sociedade. É isso que estava contido, por exemplo, na famosa frase de Margaret Thatcher - "Não existe essa coisa de sociedade" - em entrevista à revista Woman's Own, em $1987^{25}$. A sociedade inexistente, de Thatcher, nada tem a ver com impossibiliade da sociedade na teoria de Laclau. O que estava em jogo, para a Dama de Ferro, era criar um "povo" em torno do estado mínimo, um significante que catalizava então as demandas por autonomia, independência, etc. (no neoliberalismo, condicionadas, claro, ao sucesso financeiro).

O que interessa a Wendy Brown (2015a) são justamente os reflexos dessa normatividade neoliberal naquilo que entendemos por democracia. Para autora, o neoliberalismo faz do mercado o princípio regulador não apenas do Estado, mas da sociedade de um modo geral (Brown, 2015a). Nas subjetividades particulares, isso se dá por meio da disseminação do ideal empresário de si, um dos conceitos

\footnotetext{
25 "Acho que atravessamos um período no qual muitas crianças e pessoas foram levadas a acreditar que, se tenho um problema, é a missão do governo resolvê-lo ou que conseguirei uma subvenção para lidar com ele ou que, se sou um sem teto, o governo deve me dar moradia - de tal modo que essas pessoas estão arremessando seus problemas sobre a sociedade. Mas, o que é a sociedade? Não existe essa coisa. O que existe são homens e mulheres, indivíduos, e famílias" (Thatcher 1987).
} 
mais importantes na abordagem foucaultiana dessa arte de governar. Para o filósofo francês, a inversão das relações do social com o econômico, operada pelo neoliberalismo, consiste na "reenformação da sociedade segundo o modelo da empresa" (Foucault, 2008, p.330).

\begin{abstract}
Ora, que função tem essa generalização da forma "empresa"? Por um lado, trata-se de desdobrar o modelo econômico, o modelo oferta e procura, o modelo de investimento-custo-lucro, para dele fazer um modelo das relações sociais, um modelo da existência, uma forma de relação do indivíduo consigo mesmo, com o tempo, com seu círculo, com o futuro, com o grupo, com a família. (Foucault, 2008, p.332)
\end{abstract}

O autor identifica nessa universalização da lógica empresarial uma tentativa de reconstituição de "pontos de ancoragem concretos em torno do indivíduo" (Foucault, 2008, p.332). Pontos de ancoragem que, por sua vez, formam o que, segundo Foucault, Alexander Rüstow chamava de Vitalpollitik. A Vitalpolitik consiste precisamente em organizar o corpo social conforme as regras da economia de mercado, mais precisamente em torno do princípio da concorrência. A concorrência, no entanto, aponta Rüstow, "é um princípio de ordem no campo da economia de mercado, mas não um princípio em torno do qual seria possível erigir a sociedade inteira" (Rüstow apud Foucault, 2008, p.333), uma vez que se trata de um princípio mais dissolvente que unificante. É preciso, portanto, constituir um quadro político e moral que sustente um Estado, para que ele seja capaz de se elevar acima dos diferentes grupos concorrenciais. Trata-se de conceber uma técnica de governo - uma governamentalidade - capaz de garantir o princípio da soberania. É nesse sentido que, para Foucault, a crítica do welfare state pelos teóricos do neoliberalismo tinha como objetivo deslocar o foco da soberania do Estado para o mercado, abrindo assim caminho para o exercício dessa arte de governar pelo mercado. É possível dizer que, nesse gesto, o neoliberalismo quebra as duas pernas que sustentam o paradoxo democrático, como concebido por Mouffe. Por um lado, o princípio da soberania popular fica comprometido, uma vez que a razão neoliberal só aceita um soberano: o mercado; por outro lado, nele a homologia entre livre mercado e liberdade civil dá lugar à redução de um ao outro. Isso porque, a princípio, a única liberdade cara ao neoliberalismo é a liberdade de empreender, a "liberdade" que desfruta o empresário (bem sucedido) de si. 
E é esse aspecto que interessa a Wendy Brown. Para a autora, o Estado, sob a batuta neoliberal, existe para o mercado. Nele, políticas fiscais, de imigração, de segurança e educação deixam de ser avaliadas da perspectiva do estado constitucional. O neoliberalismo, em grande medida, prescinde da Constituição ou do Contrato Social: o neoliberalismo produz soberania a partir da economia. $\mathrm{O}$ que mede a eficácia do estado neoliberal, o que determina hoje o sucesso ou o fracasso um governo, de uma gestão, de uma administração, não é a sua fidelidade a um conjunto de princípios constitucionais, mas ao imperativo do crescimento econômico - da mesma forma que o que determina o sucesso de qualquer empresa é o lucro auferido.

Pior: não se trata simplesmente de fazer do crescimento (da autovalorização do capital) a razão de ser do Estado, mas de tudo submeter à racionalidade mercadológica. O discurso oficial do estado neoliberal - presente nas declarações de presidentes, ministros, congressistas - está sempre sob o signo do empreendedorismo, articulando termos, imagens, metáforas próprias desse universo. "É um Estado que não deve simplesmente se conformar ao mercado, mas pensar e se comportar como um ator do mercado em todas as suas funções, incluindo a lei" (Brown, 2015, p.42). No regime neoliberal, portanto, a legitimidade deste ou daquele governo aparece atrelada ao crescimento econômico: "a grade econômica vai permitir, e deve permitir testar a ação governamental, aferir sua validade, deve permitir objetar à atividade do poder público seus abusos, seus excessos, (...) seus gastos” (Foucault, 2008, p.338). O governo, no neoliberalismo, é submetido a um tribunal econômico permanente.

$\mathrm{O}$ mesmo se aplica à conduta individual das pessoas que constituem esse Estado e que tem no homo oeconomicus o seu cidadão modelo. Isso porque, ao serem concebidos como empresas, os indivíduos ditos racionais são convertidos em analistas de riscos, sua autonomia moral passa a ser medida por sua capacidade de tomarem conta de si mesmos, sua capacidade de atenderem às próprias necessidades e correrem atrás de seus objetivos, de suas ambições, seja individualmente, seja por meio de associações:

a generalização da forma econômica do mercado no neoliberalismo americano, além das próprias trocas monetárias, funciona como princípio de inteligibilidade, princípio de decifração das relações sociais e dos comportamentos individuais. O que significa que a análise em termos de economia de mercado, em outras palavras, 
em termos de oferta e procura, vai servir de esquema que se pode aplicar a campos não econômicos, em comportamentos não econômicos. (Foucault, 2008, p.334)

Apaga-se, dessa forma, a diferença entre comportamento moral e cálculo econômico, uma vez que a moral se resume à deliberação quanto aos custos, benefícios e consequências. Tudo passa a ser pensado em termos de "capital humano" (Foucault, 2008, p.334). O empresário de si não estuda, investe em educação. Não vai a festas, faz networking. Mesmo as relações familiares são vistas em termos de crédito ou débito, onde o amor e a dedicação dos pais aos seus filhos renderá, no futuro, um cargo de prestígio, um alto salário.

[O] indivíduo racional calculador assume responsabilidade completa pelas consequências de seus atos, não importa quão severos sejam os limites [constraints] de sua ação - por exemplo, falta de habilidades, educação de cuidados na infância durante um período de alto desemprego e benefícios sociais limitados. Correspondentemente, uma "vida mal gerenciada", a apelação neoliberal para o fracasso para contornar os obstáculos para a prosperidade se torna um novo modo de despolitizar poderes sociais e econômicos ao mesmo tempo que reduz a cidadania política a um grau sem precedentes de passividade e complacência política. (Brown, 2015, p.43)

O cidadão neoliberal modelo - o sujeito do Estado neoliberal - é um estrategista. Planeja seus investimentos em formação, seus investimentos afetivos, suas relações, trabalha pela manutenção de sua imagem, valoriza sua marca. As universidades americanas, aponta Wendy Brown, se adaptam a essa lógica. Nomes de instituição, títulos e cursos "agregam valor", como se diz no mundo corporativo. E é dessa forma que esse cidadão é interpelado nas campanhas políticas: simultaneamente como empresário e como consumidor. Enquanto empresário de si, o homo oeconomicus torna-se governável pelo Estado, que por sua vez não tem para com ele responsabilidade alguma, pois, “(...) como 'empreendedores' individuais em todos os aspectos da vida, os sujeitos se tornam completamente responsáveis por seu bem-estar e a cidadania é reduzida ao sucesso nesse empreendimento" (Brown, 2015a, p.44). É por meio dessa liberdade que o sujeito neoliberal é controlado, mais precisamente, por meio da "moralização das consequências dessa liberdade" (Brown, 2015a, p.44).

Em sua tentativa de identificar o que há de específico no neoliberalismo, Wendy Brown não se afasta muito da trilha percorrida por Foucault em seu curso. Reconhece que a transposição da lógica econômica para as relações sociais pode 
ser desdobrada tanto a partir de Marx $^{26}$, quanto dos conceitos de racionalidade instrumental e desencantamento do mundo em Max Weber. Para ela, no entanto, o que pode se perder nessa análise é: 1) a ruptura histórico-institucional que o neoliberalismo significa; 2) a forma de governabilidade que ele substitui; 3) a forma que ele inaugura; 4) as modalidades de resistência que ele torna obsoletas; e 5) aquelas que devem ser desenvolvidas para que seja possível desafiá-lo efetivamente.

Para a autora, o neoliberalismo não é mero resultado do desenvolvimento histórico do capital e da racionalidade instrumental, mas fruto de uma articulação entre os dois; não é apenas a conjunção de dois processos impessoais, portanto, mas produto também de um kairós que institui um corte novo no interior da sociedade. Nenhuma dessas análises dá conta da articulação discursiva de moral, economia, racionalidade política e penal promovida por essa mudança, o que implica na perda de autonomia relativa entre as diferentes instituições responsáveis pelas leis, pelas eleições, pela política e pela esfera pública -, algo que sustentava a separação clássica entre a economia-política capitalista e o sistema político nas antigas democracias liberais.

Quando princípios democráticos de governança, códigos civis, e até mesmo a moralidade religiosa são submetidos ao cálculo econômico, quando nenhum valor ou bem escapa a esse cálculo, então as fontes de oposição à - e a mera modulação $\mathrm{da}$ - racionalidade capitalista desaparece. (Brown, 2015a, p.46)

Nos últimos dois séculos, afirma Brown, o que a democracia liberal nos proporcionou foi um modesto gap entre economia e política - mesmo quando na política defendiam-se as bandeiras do individualismo, da propriedade etc. Ao manter uma pequena distinção entre os princípios morais e políticos, de um lado, e a ordem econômica, de outro, esse arranjo garantia aos indivíduos aos menos um espaço isolado da lógica econômica. "É esse gap que a racionalidade política neoliberal fecha ao submeter todos os aspectos da vida social ao cálculo

\footnotetext{
26 "A racionalidade política do neoliberalismo pode ser lida como resultado de um estado do capitalismo que simplesmente ressalta o argumento marxista de que o capital penetra e transforma cada aspecto da vida - refazendo tudo à sua imagem e reduzindo todo valor e atividade à sua fria racionalidade. A única novidade aqui seria a flagrante e impiedosa submissão do estado e do indivíduo, da igreja e da universidade, moralidade, sexo, casamento e do lazer a essa racionalidade. Ou melhor, a única novidade seria a recém conquistada hegemonia da teoria da escolha racional nas ciências humanas, autorrepresentada como um ramo do conhecimento independente e objetivo em vez de uma expressão da dominância do capital." (Brown, 2015a, p.45).
} 
econômico" (Brown, 2015a, p.46). É nisso que consiste, para a autora, o efeito desdemocratizador do neoliberalismo. Para ela, a democracia liberal é incapaz de sobreviver à razão neoliberal. E é justamente essa democracia desdemocratizada que, hoje, espalhou-se pelo mundo.

Não há nada nas instituições e nos valores básicos da democracia liberal - de eleições livres, democracia representativa e liberdades individuais igualmente distribuídas ao compartilhamento modesto do poder ou mesmo participação política substantiva - que atenda inerentemente ao teste de servir à competitividade econômica ou naturalmente resiste uma análise de custo-benefício. (Brown, 2015, p.46)

Para a autora, a cruzada norte-americana para levar democracia ao Oriente Médio, no começo deste século, dá indicativos da precariedade dessa democracia, onde restam poucos espaços para liberdades civis igualmente distribuídas, imprensa minimamente independente das corporações, eleições confiáveis, educação pública de qualidade, um judiciário imune à influencia política e comercial...

Nenhum desses elementos constitutivos da democracia liberal jamais foi completamente realizado em sua breve história - eles sempre foram comprometidos por uma variedade de poderes econômicos e sociais da supremacia branca ao capitalismo. E as democracias liberais no Primeiro Mundo sempre exigiram que outras pessoas pagassem - política, social e economicamente - pelo que essas sociedades usufruíam; ou seja, sempre houve uma inflexão imperialista e colonialista a separar o que era valorizado no centro e o que era requerido da periferia. (...) Sem precedentes nesta época é a extensão com que tais princípios básicos e instituições da democracia estão se tornando nada mais do que cascas ideológicas que escondem o seu oposto bem como a extensão com que esses princípios e instituições, mesmo enquanto valores, vêm sendo abandonados por largas parcelas da população americana. (Brown, 2015, p.52)

Diante disso tudo, a pergunta que se impõe é a seguinte: como pensar o populismo, em sua relação inextricável com o princípio democrático da soberania popular, num universo em que isso deixa de ser um valor?

Como parece apontar a análise de Lordon, o capitalismo não precisa ser abordado em termos de determinismo histórico para que sua importância na configuração do social seja reconhecida. Arranjos contingentes também produzem efeitos - e afetos - necessários. É possível tirar muitas lições sobre organização política do estudo da trajetória do pensamento coletivo neoliberal, do processo que conduziu o Colóquio Walter Lippman, passando pela fundação da Sociedade 
Mont Pèlerin, pela influência crescente da Escola de Chicago, pela disseminação das ideias neoliberais na mídia e no mundo empresarial, tudo isso com o auxílio precioso dos think tanks e da ocupação lenta e gradual, num ritmo de guerra de trincheira, das cátedras de economia das universidades e dos postos decisórios das instituições financeiras e órgãos internacionais, como o FMI e o Banco Mundial, e, por fim, dos cargos públicos, dos ministérios de economia e fazenda de inúmeros países (Mirowski e Plehwe, 2009). É isso que acreditam, por exemplo, Nick Srnicek e Alex Williams (2015), quando defendem a criação de um "Mont Pèlerin da esquerda". Acontece que, também nesse caso, como ocorre por vezes na abordagem pós-marxista de Laclau e Mouffe, não se pode perder de vista os efeitos necessários do modo de produção capitalista, ainda que o saibamos contingente. É preciso estar atento para o fato que qualquer iniciativa contrahegemônica, "de esquerda", nos moldes dessa empreendida pelo pensamento coletivo neoliberal, dependeria de um esforço redobrado, pois não estaria disputando apenas um campo simbólico e afetivo com o discurso hegemônico, mas entraria em choque com a imensa máquina do Capitalismo Mundial Integrado, para usar o termo de Felix Guattari (Guattari and Rolnik, 1986). Empresas, instituições financeiras, fundos de investimento, e seus lobbies, seu controle sobre fluxos de dinheiro, tecnologia e poderio militar, fluxos que perpassam todo o tecido social. Como aponta Fredric Jameson:

Lamenta-se frequentemente que o marxismo pareça uma teoria puramente econômica, que deixa pouco espaço para uma teoria propriamente marxista. Acredito que essa é a força do marxismo, e que a teoria e a filosofia política são sempre epifenomênicas. A política deve ser objeto de um oportunismo sempre vigilante, mas não de nenhuma teoria ou filosofia; e mesmo os atuais esforços para redefinir a democracia de massa nessa ou naquela direção, são, no meu entender, distrações do tema principal que é a natureza e a estrutura mesma do capitalismo. Jamais existirão soluções políticas ou sistemas satisfatórios; mas poderão existir soluções econômicas melhores, e marxistas e esquerdistas têm que se concentrar nisso. (Jameson, 2010)

À primeira vista, há que se reconhecer que isso parece ir na contramão de todo esforço empreendido pelo pós-marxismo - descrito nos primeiros dos capítulos deste trabalho - para restituir o privilégio do político na configuração do social. A ideia, é preciso deixar claro, não é essa. Como já dito, subscrevem-se aqui as teses de Laclau sobre o populismo como lógica do político, bem como a ideia da sociedade impossível, cuja plenitude, para além dos arranjos 
hegemônicos, seria apenas uma quimera (ou um espectro, no sentido derrideano). O que se quer recusar, no entanto, é a ilusão de que, se a sociedade é impossível, tudo é permitido. Que o social pode ser reconfigurado a bel prazer, que para isso bastaria, digamos, vontade política. O que se recusa é a ideia de que bastaria construir o significante vazio perfeito para estabelecer as cadeias de equivalência entre as demandas insatisfeitas acumuladas à margem do sistema e - voilà! -, nossos problemas acabaram. Um populismo incapaz de mexer com as estruturas macroeconômicas estará condenado a repetir, ad infinitum, a profecia de Lampedusa: é um populismo que tudo muda para que tudo continue igual. Se essas duas dimensões aparecem, no entanto, articuladas, é possível que os resultados sejam mais promissores. O populismo, nesse sentido, precisaria ser encarado não apenas como forma de catalisar afetos (de frustação, de indignação, de revolta etc.) que atravessam o tecido social, como também para suscitar outros tipos de afetos (de esperança, de devoção, de segurança, de contentamento, de estima etc.). É nesse sentido que uma abordagem espinosista será defendida mais à frente como forma de complementar a abordagem psicanalítica, privilegiada por Laclau na teoria do populismo. O caráter relacional da dimensão afetiva, o paralelismo entre mente e corpo, pensamento e extensão, aponta caminhos interessantes para pensarmos o vínculo entre as relações materiais - que acontecem simultaneamente num tempo histórico e num espaço geográfico profundamente afetados pelo modo de produção capitalista - e as relações afetivas - o atravessamento das paixões - sob o regime espaço-temporal configurado pela dinâmica do capital.

\section{4}

\section{A nova armadura institucional do capitalismo e a desdemocratização}

O processo de desdemocratização promovido pela hegemonia do pensamento coletivo neoliberal e a consequente disseminação da razão neoliberal, como descrito por Wendy Brown, coincide com o que Streeck (2012) descreve como o fim do capitalismo democrático, o arranjo que prevaleceu no pós-guerra.

O reaganismo, deste lado do Atlântico, e o thatcherismo, no velho continente, decretaram o início de uma nova era para a economia política. A necessidade de proteger a democracia de restrições impostas pelo livre mercado 
parece ter perdido importância na agenda governamental, dando lugar, por sua vez, a um embate direto entre os governos neoliberais e as organizações de trabalhadores $^{27}$, processo que levaria a transformações radicais na relação entre capital e trabalho. Essa mudança de postura, por parte dos governos, contribuiu para estabelecer um padrão para os governos neoliberais pelo mundo e decretou o fim da política de pleno emprego, que prevalecera no período anterior. "Os experimentos conduzidos por Reagan e Thatcher com seus eleitorados foram observados com grande atenção por formuladores de políticas do mundo inteiro" (Streeck, 2012, p.43). Essa foi, sem dúvida, uma mudança significativa operada pela ascendência do pensamento neoliberal na política governamental. Streeck (2013) localiza nessa passagem do modelo keynesiano/fordista para o neoliberal/pós-fordista as origens da crise de 2008. Isso pode ser visto também, de outra perspectiva, como um sintoma de uma nova mudança estrutural no capitalismo (Lordon, 2015).

Streeck (2012) argumenta que o controle da inflação trouxe para os governos um outro problema: o aumento da dívida pública. De um lado, porque a estagnação da economia indispunha os contribuintes, que não queriam pagar mais impostos. De outro, porque o aumento do desemprego aumentava as despesas dos Estados com assistência social. ${ }^{28}$ "Por algum tempo, a dívida pública se mostrou um equivalente funcional conveniente da inflação" (Streeck, 2012, p.45) como forma de "estreitar a lacuna entre as demandas dos cidadãos e as dos 'mercados"" (Streeck, 2012. P.45). Da mesma forma que a inflação, o endividamento dos Estados também permitia a introdução de recursos ainda não gerados na

\footnotetext{
27 “Tanto nos Estados Unidos como no Reino Unido, a desinflação foi acompanhada de ataques abertos aos sindicatos por parte dos governos e dos empregadores, cujos casos emblemáticos foram o triunfo de Reagan sobre a Organização Sindical dos Controladores de Tráfego Aéreo e o de Thatcher sobre o Sindicato Nacional dos Mineiros. Nos anos seguintes, as taxas de inflação permaneceram continuamente baixas em todo o mundo capitalista, ao passo que o desemprego aumentou mais ou menos regularmente. Paralelamente, a sindicalização declinou em quase todos os lugares, e as greves se tornaram tão esporádicas que alguns países deixaram de manter estatísticas sobre elas" (Streeck, 2012, p.43).

28 "A dívida pública crescente dos anos 1980 tinha diversas causas. A estagnação do crescimento indispusera os contribuintes mais do que nunca à tributação, e com o fim da inflação também acabaram os aumentos tributários automáticos por meio do 'bracket creep'. O mesmo se aplicava à contínua desvalorização da dívida pública em razão do enfraquecimento das moedas correntes, um processo que a princípio complementava o crescimento econômico e que passou a substituí-lo cada vez mais, reduzindo a dívida acumulada de um país em relação à sua receita nominal. No lado da despesa, o crescente desemprego, causado pela estabilização monetária, requeria gastos crescentes em assistência social. Ademais, os vários direitos sociais criados nos anos $1970 \mathrm{em}$ troca de moderação dos sindicatos nas negociações salariais - por assim dizer, salários adiados da era neocorporativista - começaram a ser cobrados, onerando cada vez mais as finanças públicas." (Streeck, 2012, p.44).
} 
economia, recursos futuros que ajudavam a apaziguar os conflitos sociais. A pressão eleitoral, paralelamente, tornou-se mais importante do que o atendimento das reivindicações sindicais. A mudança no tipo de pressão sofrida levou a uma mudança de estratégia por parte dos governantes.

Em vez de inflacionar a moeda corrente, os governos começaram a tomar empréstimos em proporções crescentes para atender demandas de benefícios e serviços como um direito dos cidadãos, assim como exigências concorrentes de que a renda refletisse o juízo do mercado e desse modo contribuísse para maximizar o uso lucrativo dos recursos produtivos. A inflação baixa - assim como as taxas de juros baixas que se seguiram à contenção da inflação - favorecia isso, já que assegurava aos credores que os títulos públicos iriam manter seu valor no longo prazo. (Streeck, 2012, p45)

Assim como no caso da inflação, a tolerância ao endividamento também tem limites. Um dos efeitos colaterais do acúmulo de dívida pública, apontado por economistas, segundo Streeck (2012), é a redução do investimento privado. O que se tem, com isso, são taxas de juros elevadas combinadas a um crescimento baixo, um mecanismo cujo limiar crítico, aponta Streeck, ainda não foi identificado. Os governos Reagan e Thatcher mostraram que, na prática, a desregulamentação dos mercados permitia a manutenção das taxas de juros baixas, enquanto se continha a inflação por meio de práticas de desmantelamento dos sindicatos. No caso dos Estados Unidos, a taxa de poupança excepcionalmente baixa levou o país a negociar os títulos da dívida pública não apenas com seus cidadãos, mas com investidores estrangeiros e fundos soberanos os mais variados. Com isso, o ônus da dívida aumentou, obrigando o país a destinar uma parte cada vez maior do orçamento ao pagamento da dívida, mesmo que as taxas de juro permanecessem baixas. Ainda que não se soubesse ao certo quando, era sabido que em algum momento os credores estrangeiros e nacionais desejariam reaver seu dinheiro e, nesse momento, se fariam sentir as pressões do mercado pela consolidação dos orçamentos públicos e pelo retorno à disciplina fiscal (Streeck, 2012).

Como relembra Streeck (2012), a questão do "duplo déficit" - o da dívida pública e o da balança comercial explodiu nos Estados Unidos na década de 1990 e foi o principal tema da campanha vitoriosa do democrata Bill Clinton para a Casa Branca, em 1992, o que "suscitou tentativas de consolidação fiscal em todo o mundo, promovidas de maneira agressiva, sob a liderança dos Estados Unidos, por organizações internacionais como a OCDE e o FMI" (Streeck, 2012, p.46). 
Em sua estratégia inicial, Clinton pretendia acabar com o déficit público estimulando o crescimento, impulsionando reformas e aumentando o investimento público em educação. Em 1994, no entanto, os democratas perderam a maioria no congresso e o governo passou a encontrar dificuldades para aprovar reformas que envolvessem mais investimento público, deixando como única alternativa para o reequilíbrio das contas o retorno a uma política de austeridade, cortes de gastos públicos.

A estratégia deu resultado. Entre 1998 e 2000, pela primeira vez em décadas, o governo dos EUA operou com orçamento superavitário. Como Clinton conseguiu reduzir o déficit público sem trazer de volta a inflação, recorrendo unicamente à política de austeridade, sem que isso produzisse uma grande insatisfação popular que abalasse o equilíbrio instável do capitalismo democrático? A resposta de Streeck: "keynesianismo privado"29.

\begin{abstract}
A feliz expressão "keynesianismo privado" foi cunhada para designar aquilo que era, em essência, a substituição da dívida pública pela dívida privada. Em vez de o governo tomar dinheiro emprestado para financiar o acesso igualitário a habitação decente ou para a formação de mão de obra qualificada para o mercado, passou a permitir - às vezes forçá-los a tanto - que cidadãos individuais, sob um sistema de endividamento extremamente generoso, tomassem empréstimos por sua própria conta e risco para pagar seus estudos ou seu acesso a um bairro menos carente.
\end{abstract} (Streeck, 2012, p.47)

O keynesianismo privado, quanto cotejado à luz da análise da razão neoliberal parece surgir como um desdobramento quase natural dessa colonização do Estado pela lógica do empresário de si. Trata-se de transferir para o âmbito privado aquilo que, no arranjo anterior, era responsabilidade do welfare state: a busca emprego, da assistência social, do acesso à saúde, à educação, à moradia.

$\mathrm{Na}$ análise de Streeck (2012), cuja ênfase está no modo de funcionamento da macroeconomia nesse contexto, o keynesianismo privado, como estratégia de Estado, conduz diretamente às subprime mortgages, as hipotecas de alto risco que produziram a bolha imobiliária que esteve na raiz da crise de 2008. A política de desregulamentação financeira beneficiou não apenas os mais ricos, poupados dos

\footnotetext{
29 “A estratégia de Clinton de gestão do conflito social se valeu intensamente do aprofundamento da desregulamentação do setor financeiro, que havia se iniciado sob Reagan A crescente desigualdade de renda, causada pela contínua dessindicalização e pelos cortes severos nos gastos sociais, bem como a redução da demanda agregada, causada pela consolidação fiscal, foram contrabalançadas pela criação de oportunidades sem precedentes para que cidadãos e pessoas jurídicas se endividassem.” (Streeck, 2012, p.46)
} 
aumentos de impostos e capazes de direcionar seus investimentos para o mercado financeiro, mas também os mais pobres, que dispunham agora de uma oferta de crédito sem precedentes, o que compensava, ainda que de maneira ilusória, o desmantelamento das redes de proteção social, o arrocho salarial e a perda de direitos trabalhistas. Ainda que por um breve período, esse cenário beneficiou, nos Estados Unidos, especialmente os afro-americanos ${ }^{30}$, cujo imenso déficit habitacional se devia, entre outras coisas, ao acesso limitado ao crédito imobiliário, por se tratar de uma população considerada de risco.

A grande novidade trazida pelo governo Clinton - e pela gestão de Alan Greenspan à frente do Banco Central norte-americano - foi, portanto, a substituição da dívida pública pela privada. A bolha de crédito criou, em linhas gerais, uma ilusão de prosperidade - ainda que, para aqueles que, individualmente, conseguiram surfar nessa onda, tenha resultado em prosperidade de fato. Em meio à política de austeridade, o crédito foi a maneira que o governo encontrou para compensar o não atendimento da "demanda pública gerida pelo Estado pela sustentação do emprego e dos lucros na construção civil e em outros setores" (Streeck, 2012, p47), o que historicamente era feito por meio de investimentos públicos em obras de infraestrutura e construção de moradias populares, entre outros. "Além de lucros sem precedentes no setor financeiro, o keynesianismo privado sustentou uma economia afluente que se tornou alvo da inveja dos movimentos trabalhistas europeus" (Streeck, 2012) e foi replicado em diversos países ${ }^{31}$. A crise das subprimes em 2008, no entanto, deu fim à "pirâmide creditícia internacional" que tornava possível esse arranjo. Para Streeck (2012), os eventos que levaram ao colapso do sistema bancário internacional em $2008 \mathrm{e}$ levaram à economia mundial ao que, para muitos, era a pior "crise" desde a Grande Depressão emergem como sintoma do fim do capitalismo democrático.

\footnotetext{
30 "As hipotecas de alto risco [subprime mortgages] se tornaram um substituto - ainda que ilusório no final das contas - para as políticas sociais, que foram sucateadas, bem como para os aumentos salariais, que se tornaram indisponíveis nos segmentos inferiores de um mercado de trabalho 'flexibilizado'. Para os afro-americanos em particular, a casa própria era não só a realização do 'sonho americano' como também um substituto fundamental para as aposentadorias, que muitos eram incapazes de obter no mercado de trabalho e a qual não tinham nenhum motivo para esperar de um governo comprometido com a austeridade permanente." (Streeck, 2012, p.46)

31 "De fato, a política de Alan Greenspan de crédito abundante respaldando o crescente endividamento da sociedade americana foi considerada um modelo por líderes sindicais europeus, que notaram com grande entusiasmo que o Fed, diversamente do Banco Central Europeu, era obrigado por lei a promover não só estabilidade monetária como também níveis de emprego elevados." (Streeck, 2012, p.47).
} 
A questão que se impõe a essa altura, se corroboramos a hipótese de Streeck (2012) sobre o fim do capitalismo democrático, é a seguinte: por que, apesar desse aparente esgotamento do modelo neoliberal como forma de gestão macroeconômica, sua hegemonia, no entanto, persiste? Por que os Estados se empenharam tanto em resgatar as instituições financeiras e, posteriormente, se recusaram a impor um limite às práticas especulativas que conduziram ao colapso econômico? Por que nos Estados Unidos o que se viu com Obama foi uma retomada do keynesianismo privado e uma defesa explícita do mercado? Por que, na Europa, a política de austeridade converteu-se em dogma, a despeito do fato que a atual crise da dívida, ao contrário do que apontava o discurso neoliberal oficial, amplamente propagado pelo Banco Mundial e pelo Fundo Monetário Internacional (FMI) ao longo dos anos 1990 e 2000, não podia ser atribuída - mas foi, como se viu, por exemplo, no caso da Grécia - aos "gastos extras inconsequentes" de "políticos oportunistas ou de órgãos públicos desavisados" (Streeck, 2012), mas unicamente ao resgate das instituições financeiras pelo Estado? ${ }^{32}$. Por que essa conta deve agora ser paga pelo trabalhador, pelo cidadão comum, convocado a fazer sacrifício - de empregos, de direitos trabalhistas, de benefícios sociais, de tudo aquilo que, um dia, lhes foi prometido pelo welfare state keynesiano, mas também do crédito fácil, do acesso aos bens de consumo, ao financiamento do empresário de si que caracterizou o "keynesianismo privado" das gestões neoliberais da economia? Por que a insatisfação popular com os desdobramentos dessa política econômica, insatisfação manifestada, por exemplo, em protestos como o Occupy Wall Street, parece não ter sido suficiente para sensibilizar os governantes imediatamente após o colapso financeiro? Por que, a

\footnotetext{
32 “O salto quântico da dívida pública após 2008, que desfez por completo toda consolidação fiscal porventura alcançada na década anterior, refletiu o fato de que nenhum Estado democrático se atreveu a impor a sua sociedade outra crise econômica da magnitude da Grande Depressão dos anos 1930, como punição para os excessos de um setor financeiro desregulamentado. Mais uma vez, o poder político foi chamado a colocar à disposição recursos futuros a fim de assegurar a paz social do presente, e os Estados, mais ou menos voluntariamente, assumiram a responsabilidade por uma significativa parcela da nova dívida originalmente gerada no setor privado, de modo a tranquilizar os credores privados. Mas se isso efetivamente respaldou as fábricas de dinheiro da indústria financeira, restabelecendo com rapidez seus extraordinários lucros, salários e bonificações, não logrou evitar a desconfiança crescente de parte dos mesmos 'mercados financeiros' de que os próprios governos nacionais, no processo de resgatá-los, poderiam ter se expandido além da conta. Mesmo com a crise econômica global longe de seu fím, os credores começaram a exigir ruidosamente um retorno ao equilíbrio monetário por meio de medidas de austeridade fiscal, buscando assegurar-se de que seus investimentos na dívida pública, enormemente ampliados, não seriam perdidos." (Streeck, 2012, p.50)
} 
despeito do grito dos "99\%", nos Estados Unidos, Obama e o establishment democrata pareciam insistir no bordão thatcheriano de que não há alternativa?

Apesar do impressionante diagnóstico, Streeck (2012) também parece não ver muitas alternativas e conclui sua análise com um tom profundamente pessimista. Pare ele, apesar de todo o apelo dos discursos nacionalistas, ainda não está claro como seria possível, hoje, desfazer os laços com o mercado internacional sem produzir escassez de recursos e produtos, o que causaria revolta nas populações ${ }^{33}$ (Streeck, 2012). Como pontua Streeck, "as crises e as contradições do capitalismo democrático se tornaram definitivamente internacionalizadas, manifestando-se não só dentro dos Estados mas também entre eles" (Streeck, 2012, p.54). Essa margem de manobra estreitíssima dos governos no capitalismo globalizado é, ao que tudo indica, uma variável fundamental para compreender a atual crise de representação - tanto no sentido filosófico quando no sentido político. Há fortes indícios nesse sentido. Um deles está precisamente na postura antiestablishment que está no centro da recente explosão populista - à esquerda e à direita - nos Estados Unidos e na Europa ${ }^{34}$.

As expectativas políticas ora apresentadas aos Estados democráticos pelos seus novos mandantes podem ser impossíveis de satisfazer. Os mercados e as instituições internacionais exigem que não só os governos como também os cidadãos se comprometam credulamente com a consolidação fiscal. Partidos políticos que se oponham à austeridade precisam ser derrotados de modo retumbante nas eleições nacionais, e tanto o governo como a oposição devem se comprometer publicamente com "finanças sadias", caso contrário o custo do

\footnotetext{
${ }^{33}$ É possível acrescentar aqui alguns exemplos nesse sentido. Entre os governos de esquerda, o caso da Venezuela é sintomático. A autossuficiência do país, que durante a gestão Hugo Chaves foi garantida pelo alta nos preços do barril de petróleo, parece não ter resistido à queda no preço das commodities, levando o país a uma crise econômica e política sem precedentes. No caso brasileiro, há quem aponte que o sucesso do governo Lula na expansão dos benefícios sociais, combinada ao crescimento econômico, é tributário do mesmo boom dos commodities. Quanto aos limites do discurso nacionalista de direita, é possível ter que esperar um pouco mais para ter exemplos concretos. Mas os primeiros meses da administração de Donald Trump, nesse sentido, não parecem dos mais promissores. Apesar de ter confirmado sua promessa de sair da Parceria Transpacífica - TPP (Trans-Pacific Partnership), o acordo de livre-comércio estabelecido entre doze países banhados pelo Oceano Pacífico, outros compromissos de campanha, como o abandono da Nafta e o equilíbrio da balança comercial com a China têm se mostrado mais difíceis de alcançar. A situação do governo inglês, pós-Brexit, também não é das mais fáceis. Ainda não se sabe ao certo como a economia inglesa vai reagir à saída do bloco europeu .

34 "Desse modo, os cidadãos cada vez mais percebem seus governos não como seus agentes, mas de outros Estados ou de organizações internacionais tais como o FMI ou a União Europeia, incomensuravelmente mais isolados da pressão eleitoral do que era o tradicional Estado-nação. Em países como Grécia e Irlanda, qualquer coisa que se assemelhe à democracia será efetivamente suspensa por muitos anos. Para proceder 'responsavelmente', no sentido definido por mercados e instituições internacionais, os governos nacionais terão de impor uma rígida austeridade, a preço de se tornarem cada vez mais irresponsáveis para com seus cidadãos.” (Streeck, 2012, p.55)
} 
serviço da dívida vai aumentar. Entretanto, pleitos em que os eleitores não tenham nenhuma opção efetiva poderão ser percebidos como inautênticos, o que talvez cause toda sorte de desarranjos políticos, da diminuição do comparecimento às urnas e a ascensão de partidos populistas aos distúrbios nas ruas. (Streeck, 2012, p.55)

A democracia contemporânea é uma democracia sequestrada, nas palavras de Streeck (2012), não apenas refém do mercado, mas operando nos limites de sua lógica.

\section{5}

\section{A razão neoliberal e a desdemocratização}

Com a hegemonia neoliberal, o que se viu nos países centrais foi uma desconstrução lenta e implacável do estado de bem-estar, que veio acompanhada de uma centralidade despótica da economia na definição da agenda política dos governos e de uma crescente desdemocratização. Na medida em que a economia se tornou um tema que deixou de ser colocado, de fato, em discussão, tornou-se matéria de especialistas e, ao fim e ao cabo, não está sujeito à escolha dos eleitores. Nesse contexto, são cada vez mais comuns as acusações de "estelionato eleitoral" - de políticos que se elegem com um programa de governo cheio de promessas de ruptura, mas, uma vez no poder, dão continuidade à cartilha do governo anterior, fazendo com que as políticas de austeridade sobrevivam à esquerda, ao centro e à direita do espectro político. Essa, aliás, foi a dinâmica mesma da "Terceira Via", que se espalhou a partir da Europa nos anos 2000 e mudou a cara do partido trabalhista inglês que, no poder, deu continuidade e até intensificou o ritmo das reformas neoliberais iniciadas por Margaret Thatcher (Mouffe 2015). Como chegamos a esse ponto?

Para Alasdair Roberts (2010), os ideólogos do neoliberalismo encontraram na doutrina do choque (Klein, 2008) uma forma de para impor a lógica da disciplina às democracias liberais. A lógica da disciplina compreende, para esse autor, o conjunto de medidas criadas para limitar ou restringir o raio de ação do Estado na economia e na implantação de políticas públicas (leis de responsabilidade fiscal, independência do banco central e restrição do seu papel à gestão da taxa de juros para controle da inflação, câmbio flutuante etc.) num processo que tem impactos profundos no modo de funcionamento das democracias capitalistas. O caminho para a imposição dessa lógica começa no 
convencimento da opinião pública, com a disseminação do ceticismo em relação aos méritos do governo democrático, acusado de produzir políticas de curto prazo, instáveis ou desenhadas para satisfazer os interesses corporativistas de grupos organizados e, em última instância, favorecer a própria burocracia do Estado, e culmina na demanda por reformas capazes de gerar políticas orientadas por uma suposta visão de longo prazo, que exige a imposição de limites ao poder dos representantes democraticamente eleitos, a fim de proteger os eleitores de suas decisões imprudentes (Roberts, 2010). A aplicação dos itens dessa cartilha, como aponta o autor, tende a produzir e multiplicar, aos poucos, ilhas de autonomia na gestão das democracias modernas: redutos de poder imunes, em grande medida, à pressão popular - mas muito sensíveis às necessidades do mercado. Isso explicaria, ao menos em parte, a persistência dos dogmas neoliberais independente da orientação política dos governantes eleitos.

Uma das teorias que muito contribui para a disseminação desse ceticismo em relação aos méritos do governo democrático, como apontam Amir Schäfer e Wolfgang Streeck (2013) é a teoria da escolha pública, que teve impacto direto nas discussões sobre a política fiscal - fundamental para determinar a supremacia da economia na definição das políticas governamentais - a partir dos anos 1970. O núcleo dessa teoria colocava nas costas dos cidadãos das democracias capitalistas a culpa pela irresponsabilidade dos governos, que para atender às demandas potencialmente infinitas dos potenciais eleitores interferiam em áreas que, no entender dessos teóricos da escolha pública, estariam melhor nas mãos da iniciativa privada e submetidas à lógica do mercado.

A tese da tragédia dos comuns desempenhou um papel estratégico na disseminação desse ponto de vista. Desenvolvido originalmente por William Forster Lloyd (1833), num estudo sobre a posse comunal da terra nas aldeias medievais, o argumento foi retomado, em 1968, pelo ecologista Garrett Hardin, no ensaio The Tragedy of the Commons. A análise de Lloyd (1833) tinha como foco a devastação das terras comuns, dos pastos, no período medieval, e tentava responder por que o gado das terras comuns tinha uma aparência tão debilitada em relação àqueles criados em terras privadas. Para o matemático, isso podia ser atribuído ao interesse individual de cada pastor, que, a fim de obter mais ganhos, colocava maior número possível de animais na terra, o que, com o tempo, resultava na destruição das pastagens. Ainda que os pastores conseguissem 
compreender as consequências desse comportantamento a longo prazo, os interesses de curto prazo, por questões de sobrevivência, prevaleciam, a menos que essa prática fosse coibida por meio de medidas coercitivas. Isso porque a consciência ou o altruísmo não são, para Lloyd, características desse ser humano orientado pelo interesse. O comportamento coletivo dos pastores, que conduz à exploração cada vez mais acelerada dos recursos, é motivado pela concorrência. No momento em que um dos pastores começa a se beneficiar do maior número de cabeças no campo, os demais pastores tendem a imitá-lo, o que resulta numa disputa pra ver quem consegue explorar mais em menos tempo, antes que o pasto acabe. Para evitar essa tragédia, acredita Lloyd, é preciso que o interesse individual seja submetido a alguma espécie de controle.

Retomando o argumento de Loyd (1833), Hardin (1968) estende o exemplo dos pastores para outros bens comuns, como a atmosfera, oceanos, rios, populações de peixes, parques nacionais etc. Acompanhando a metáfora da pastagem, Hardin argumenta, com base em estudos, que o "cercamento" dos bens comuns, assim submetidos a métodos diferentes de uso regulamentado, oferece um método mais confiável que a fé na consciência humana como meio de preservação dos comuns. A tragédia dos comuns e a metáfora dos pastores influenciaram significativamente a política preservacionista e a criação de parques e reservas federais pelo mundo.

Embora se trate, desde sua origem, de uma teoria controversa, muito criticada, sobretudo, pela imagem que faz do ser humano como naturalmente egoísta e guiado exclusivamente pelo interesse, em seu ensaio Hardin não incorre numa defesa da privatização dos bens comuns. Até porque, de certo modo, mantendo-se o pressuposto que o interesse individual permanece na base do comportamento, a privatização não seria nada mais do que uma mudança de escala, onde o lugar dos pastores, na analogia, seria substituído por corporações, por empresários, e o do pasto pelo planeta inteiro. Mas é precisamente deste modo, como defesa da privatização dos comuns, que a tragédia dos comuns é intrumentalizada pela teoria da escolha pública e, ao mesmo tempo, serve para atacar a democracia.

$\mathrm{Na}$ versão popular da teoria, a democracia é a principal culpada, com seus protagonistas - eleitores, grupos de interesse e partidos políticos - retratados como 
fundamentalmente irresponsáveis e incapazes de resistir às tentações inerentes ao livre acesso aos bens coletivos. Como suas instituições são vulneráveis à pressão popular, a história segue, a democracia vai resultar inevitavelmente em decisões econômicas irracionais, incluindo o comprometimento com gastos públicos que excedem as receitas e um endividamento crescente. (Schäfer and Streeck, 2013)

Para Schäfer and Streeck (2013), a teoria da escolha pública tem um "sabor hayekiano" em sua defesa de economia que deveria manter-se longe de influências eleitorais ou políticas (por exemplo, pode-se acrescentar as ilhas de autonomia descritas por Roberts (2010), como os bancos centrais independentes, as autoridades regulatórias ou a Comissão Europeia).

Mas o que os autores entendem, precisamente, por sabor hayekiano? Uma análise dos comentários de Hayek sobre a democracia, e os perigos do princípio da soberania popular, pode ser encontrada no terceiro volume de Law Legislation and Liberty (Hayek, 1979), em que o autor começa invocando os perigos da vontade popular, que, argumenta, muitas vezes produz resultados que não mereceriam 'o nome de 'vontade comum' [common will] de nenhuma parte substancial da população" (Hayek, 1979, p.1). Para o fundador da Sociedade Mont Pèlerin, o ocidente acostumou-se a pensar no modelo representativo de democracia, no qual um corpo de representantes eleitos elabora as leis e governa por meio delas, como a única forma possível de democracia. Isso muitas vezes nos impediria de lidar com o fato de que tal sistema

não apenas produz muitos resultados que ninguém gosta, mesmo naqueles países que, em linhas gerais, funciona bem, mas também provou-se desfuncional na maioria dos países onde essas instituições democráticas não estão restringidas por fortes tradições relativas às tarefas apropriadas das assembléias legislativas. (Hayek, 1979, p.1)

Para expoente da Escola Austríaca, o que o histórico parece indicar é que, após um período inicial em que, de fato, a democracia opera como uma garantia das liberdades individuais, por ainda serem aceitas as limitações de um nomos mais elevado (tradições e valores compartilhados pela comunidade na qual a democracia emerge como sistema político), ela "cedo ou tarde reivindica o direito de resolver toda questão particular por meio de seja qual for a forma que a maioria concordar" (Hayek, 1979, p.2). Esse argumento, deve-se reconhecer, não é novo. É possível encontrar nele um "sabor platônico", por lembrar o processo descrito na República, diálogo em que Sócrates descreve o caminho que leva da 
democracia à tirania, passando pela anarquia. Para Hayek, é possível observar desdobramentos similares àqueles verificados na democracia grega, quando se observa, por exemplo, o parlamento britânico, na revogação dos princípios constiticionais monárquicos que teriam tido origem numa encruada luta para estabelecer limites ao poder soberano do rei. Era disso, ele defende, que se abria mão em nome da soberania popular, que o parlamento supostamente representava. Esse mecanismo, argumenta o autor, já tinha sido identificado por Aristóteles ao postular que não existem leis soberanas - e, consequentemente, não existe constituição - onde a lei emana do povo como representação de uma vontade coletiva da maioria, como acontece nas democracias.

Para Hayek, a ideia de que a democracia pode prescindir de mecanismos de controle e limitação do poder é uma ilusão. Sobretudo porque dissemina a crença de que o controle do governo, pelos representantes democraticamente eleitos, substitui as limitações tradicionais, quando na realidade o que acontece é que essa representação não traduz a vontade geral, mas a vontade de determinados grupos de interesse, que constituem a base eleitoral desses representantes. Para Hayek, paradoxalmente, o poder ilimitado conferido aos representantes, nas modernas democracias, impede que os princípios gerais prevaleçam, porque, sob o princípio da maioria, para continuar maioria, esse corpo representativo precisa fazer tudo que está ao seu alcance para comprar o apoio dos diversos grupos de interesse, assegurando-lhes benefícícios especiais. Para Hayek, em suma, nada pode nos assegurar que instituições democráticas garantirão a representação do que acreditamos ser a vontade da maioria. Para Hayek, o mais provável é que o abandono do império da lei conduza à "democracia totalitária" ou à "ditadura plebiscitária".

Depois de levar adiante tais críticas, Hayek dá um passo atrás. Reconhece o valor da democracia para a garantia da liberdade, desde que dentro de certas condições. Uma delas é limitar o princípio da soberania popular, como forma de assegurar que vontade da maioria não termine por oprimir grupos minoritários, que não conseguiram ter sua vontade representada. O ponto crucial, para ele, é que "votos em leis que se aplicam a todos, e votos em medidas que afetam diretamente apenas alguns, tem um caráter completamente diverso" (Hayek, 1979, p.8). Para ele, leis que se aplicam a todos baseiam-se em opiniões duradouras e 
diferem, portanto, de medidas que atendem a este ou aquele grupo, em detrimento do interesse geral.

Mas os eleitores de uma "legislatura" cujos membros estão preocupados principalmente com garantir e reter os votos de um grupo em particular, procurando obter-lhes benefícios especiais, pouco se importam com o que os outros vão ganhar com isso e só querem saber com o que eles mesmos têm a ganhar nessa negociata. Eles simplesmente concordaram tranquilamente com algo ser dado a outro que eles pouco sabem a respeito, e normalmente às expensas de um terceiro grupo, como um preço a ser pago para ter seus interesses atendidos, sem sequer se perguntar se essa demanda é justa. Cada grupo estará preparado para consentir até mesmo com benefícios iníquos, sacados da carteira comum, para outros grupos se essa for a condição para obter o consentimento dos outros para aquilo que esse grupo aprendeu a ver como seu direito. $\mathrm{O}$ resultado desse processo não corresponderá à opinião de ninguém sobre o que é um direito, e a nenhum princípio; não será julgado num julgamento do mérito, mas na conveniência política. Seu objeto principal está condenado a se tornar o compartilhamento dos fundos extorquidos de uma minoria. Que esse é o resultado inevitável de uma legislatura "intervencionista" sem limites já foi algo claramente antevisto por teóricos da democracia representativa. Quem, de fato, acredita que as legislaturas modernas garantiram todos os subsídios especiais, privilégios e outros benefícios de que tantos grupos gozam porque acreditam que essas demandas são justas? Que A seja protegido das importações baratas e B de ser substituído por um operador menos treinado, $\mathrm{C}$ da redução de salários e $\mathrm{D}$ do desemprego nada tem a ver com $\mathrm{o}$ interesse geral, embora muitos advogados dessas medidas finjam que seja. E isso não ocorre tampouco porque os eleitores estejam convencidos de que esse seja o interesse geral, mas porque esperam o apoio daqueles que defendem tais demandas que eles, a seu turno, estejam preparados para atender às suas [dos eleitores] demandas. (Hayek, 1979, p.9-10).

Para Hayek, isso que ele chama de "mito da justiça social” é, em grande medida, produto da máquina democrática, "que torna necessário para os representantes inventar uma justificação moral para os benefícios que garantem para interesses particulares" (Hayek, p.10). Daí em diante, o autor desdobra uma série de argumentos. Afirma que a vontade da maioria não passa de uma ficção, que o que emerge da máquina democrática é mero resultado do poder de barganha dos diversos grupos de interesse. Afirma ainda, apoiando-se em Kant, que "só um governo limitado pode ser um governo decente, porque não existem (e não podem existir) regras morais gerais para a distribuição de benefícios particulares" (Hayek, 1979, p.11). Defende que, se na ausência de uma autoridade judiciária superior, nada pode impedir legisladores de beneficiarem esses ou aqueles grupos e não há limites para a chantagem política. Os grupos de interesse conduzem aos lobbies dos mais diversos tipos, que exercem pressão sobre o poder público na defesa de interesses cada vez mais específicos. Os partidos políticos convertem-se 
em defensores desses interesses, de acordo com a conveniência política. As diferenças entre as legendas se anulam e, aos poucos, os eleitores são obrigados a escolher entre programas em que a única opção é entre o "mal menor, nomeadamente, entre os diferentes benefícios providos para outros às suas custas" (Hayek, 1979, p.15). O autor vê nisso um resultado inevitável de um sistema que garante ao governo poderes ilimitados para satisfazer os interesses de seus eleitores ${ }^{35}$.

É nesse ponto que a necessidade de submeter o Estado à economia é asseverada - e é nesse ponto que podemos encontrar o núcleo duro da retórica que, segundo Roberts (2010), prepara o caminho para a lógica da disciplina. Hayek reconhece que alocar recursos para atender demandas é, sim, uma das atribuições dos governantes. Hayek argumenta, entretanto, que essa prerrogativa governamental "assume proporções alarmantes quando governo e criação das leis se confundem e as pessoas que administram os recursos também determinam que parcela desse total o governo deve controlar" (Hayek, 1979, p16). Não é precisamente esse o papel das leis de responsabilidade fiscal, do banco central independente (e de medidas como a do teto dos gastos com educação e saúde, aprovada recentemente pelo governo de Michel Temer no Brasil)? Para Hayek (1979), a única defesa de um governante contra as pressões dos grupos de interesse é poder remeter-se a um princípio superior, que o impeça de fazê-lo e que não possa ser alterado por ele. São as ilhas de autonomia no oceano democrático, apontadas por Roberts (2010). São os lugares inacessíveis à soberania popular: it 's the econonomy, stupid ${ }^{36}$.

Para justificar a necessidade dessas ilhas de autonomia, Hayek (1979) recorre ao argumento do domínio técnico. Nem os governantes eleitos, nem os seus eleitores são capazes de processar a quantidade de informações necessárias para compreender "a estrutura complexa que constitui uma sociedade" Hayek,

\footnotetext{
35 “Um governo com tais poderes não pode se recusar exercê-lo para desse modo preservar o apoio da maioria. Não temos direito de culpar os políticos por fazerem o que devem ser feito na posição em que os colocamos. Nós criamos as condições nas quais é sabido que a maioria tem poder para conferir a qualquer parcela particular da população o que quer que ela demande. Mas um governante que possui tais poderes ilimitados pode permanecer no comando apenas satisfazendo um número suficientemente grande de grupos de pressão para assegurar para si o apoio da maioria". (Hayek, 1979, p.15).

${ }^{36} \mathrm{~A}$ frase, que se tornou célebre, é do estrategista da campanha de Bill Clinton, James Carville, e foi pronunciada numa das campanhas do democrata à presidência. A frase era uma das três mensagens nas quais os trabalhadores da campanha de Clinton deveriam se concentrar.
} 
(1979, p.16). Essa estrutura complexa corresponde, para Hayek, à catalaxia, o conjunto de todas as economias existentes numa sociedade; conjunto que teria no mercado o mecanismo mais eficiente para acompanhar seus movimentos.

(...) maioria pode exercer algum controle sobre os resultados do processo do mercado apenas se se conforma aos princípios gerais e se abstém de interferir nos casos particulares, mesmo quando os resultados concretos entram conflitam com seus desejos.

$(1979,19)$.

Em outras palavras, para Hayek, tal qual para Thatcher, não há alternativa. O que de melhor podemos esperar é que os técnicos do governo, os especialistas, os "tecnocratas" assegurem o bom funcionamento do mercado - e nos conformar com os resultados.

Curiosamente, a argumentação hayekiana apresenta muitos pontos em comum com as críticas de Wendy Brown (2015b) ao neoliberalismo, mas com alguns sinais trocados. Grande parte das ameaças à liberdade que Hayek vê na soberania popular, com seus grupos de interesses, Brown identifica na soberania do mercado, com seus lobbies, suas propinas, seus financiamentos de campanha... O que se pode argumentar, a partir das críticas da autora, é que o que ocorre é que o mercado se apropria do Estado, no neoliberalismo. Oficialmente, para garantir que a "mão invisível" cumpra seu papel; na prática, no entanto, tornando objeto de disputa exclusiva entre atores do capital, seja ele empresarial ou financeiro, o que antes era objeto de disputa entre grupos de interesse diversos (que representavam tanto os interesses do capital, por meio dos lobbies corporativos quanto das câmaras de comércio, dos sindicatos patronais etc., quanto dos grupos destituídos de capital, como os sindicatos, movimentos sociais, organizações estudantis, coletivos, associações de moradores, minorias organizadas etc.).

Essa colonização pelo mercado, conforme visto anteriormente, não se limita aos governos, mas se estende às subjetividades. A razão neoliberal submete tudo e todos ao princípio de competição artificial ${ }^{37}$, promove a "economicização" do Estado e das políticas sociais, substitui o comércio pela competição e o princípio

\footnotetext{
37 "Se, para os neoliberais, a competição econômica é essencial (um eidos, denomina Foucault a certa altura) e valiosa, não natural, então ela precisa ser continuamente apoiada e corrigida de fora, e essa necessidade define uma das funções cruciais do estado neoliberal.” (Brown, 2015b, p.63)
} 
da igualdade - perante a lei, pelo menos - pela naturalização da desigualdade ${ }^{38}$, o capital humano substitui o trabalho ${ }^{39}$. O empreendedorismo, por sua vez, substitui a produção ${ }^{40}$, passa-se a exercer-se um uso tático da $1 \mathrm{ei}^{41}$, o mercado converte-se num locus de verificação da verdade ${ }^{42}$ e o consenso político substitui a individuação e a contestação política ${ }^{43}$ (Brown, 2015b). Para a autora, tudo isso tem impactos brutais não apenas no que entendemos por democracia. Seja ela compreendida como soberania popular, seja como paradoxo democrático, porque os ideais liberais que Mouffe encontrava na origem da concepção moderna de democracia também mudam como consequência não apenas da razão neoliberal, mas da mudança estrutural do capitalismo, cujos desdobramentos ela ajuda entender, mas dos quais não pode ser compreendida como causa. Para pensar essa mudança, Brown (2015b) recorre aos insights de Foucault, construídos na aurora do neoliberalismo, mas procura ir além deles e pensar no mundo por vir, à medida em que, aparentemente, nos aproximamos de um possível ocaso do neoliberalismo.

\footnotetext{
38 “A competição como um princípio central da racionalidade de mercado também significa que os sujeitos perdem as garantias de proteção do estado liberal. A competição proporciona vencedores e perdedores; o capital obtém sucesso destruindo ou canibalizando outros capitais. Portanto, quando a competição de mercado se torna generalizada como um princípio social e político, uns vão vencer, outros vão morrer" (Brown, 2015b, p.64-5). "Também importante, embora não esteja entre as preocupações de Foucault, quando a racionalidade política neoliberal está completa, quando só resta o homo oeconomicus em todas as esferas e o próprio domínio do político é apresentado em termos econômicos, a figuração dos seres humanos como capital humano elimina as bases de uma cidadania democrática, nomeadamente, de um demos preocupado em asseverar sua soberania política." (Brown, 2015b, p.65)

39 "Quando a competição se torna o princípio base do mercado, todos os atores do mercado são encarados como capital, em vez de produtores, vendedores, trabalhadores, clientes ou consumidores."(Brown, 2015b, p.65)

40 "A produção é priorizada em relação ao produto; a empresa é priorizada em relação ao consumo e a satisfação." (Brown, 2015b, p.65)

41 "Governar para o mercado significa que a soberania e a lei se tornam suporte para a competição, não para os direitos (...). Uma sociedade empresarial, diz Foucault, multiplica o atrito e, como consequência, multiplica as leis e expande a jurisprudência.” (Brown, 2015b, p.65).

42 "A economia já tinha sido alinhada com a verdade no liberalismo clássico, quando o governo econômico tornou-se o bom governo e o comportamento econômico, como nos lembra Weber, se equivalia a obedecer a Deus (o Deus protestante). Mas com o neoliberalismo, o mercado se torna $o$, em vez de um sítio de verificação $e$ se torna tal em toda arena e em todo tipo de atividade humana." (Brown, 2015b, p.67)

43 "Foucault não é muito capaz de apresentar essa alegação sobre integração e consenso num argumento completo, mas deixa marcadores para que isso seja feito. Ele nota que 'o mercado economicamente livre vincula e manifesta vínculos políticos' e que a 'produção de bem-estar pelo crescimento econômico vai produzir um circuito que vai da instituição econômica da adesão geral da população a esse regime e sistema."(Brown, 2015b, p.65)
} 


\section{6 O ocaso neoliberal: mudança estrutural e causalidade imanente}

Um aspecto interessante, é que uma das características do neoliberalismo, que fica evidente nas análises de Wendy Brown, é que nele só há espaço para o que Laclau denomina lógica da diferença. As demandas, nele, só podem ser encaminhadas e processadas diferencialmente, individualmente. O que a autora observa, é que, especialmente da última década pra cá, o neoliberalismo intensificou radicalmente essa tendência. Wendy Brown (2015b) enumera doze fatores representativos do atual momento do neoliberalismo que, postula-se aqui, poderiam ser interpretados como sintomas de uma mudança na armadura institucional do capitalismo e ajudam a dar conta da complexidade da relação contemporânea entre o capital, o Estado, a democracia e a produção de subjetividades. Cabe destacar aqui que esses itens, elencados por Brown, parecem apontar não só para a prevalência da lógica da diferença, mas também para um cenário de institucionalização extrema, como aquele que costuma anteceder os levantes populistas, segundo Ernesto Laclau. De maneira sucinta, os doze pontos são os seguintes:

1) $O$ protagonismo do capital financeiro e a financeirização generalizada. $O$ capital financeiro tem hoje uma importância muito mais significativa do que tinha na época da aurora neoliberal. Esse fenômeno vem acompanhado da centralidade crescente da questão da dívida e dos derivativos para os Estados (um dos temas já abordados brevemente no capítulo anterior, a partir do artigo de Streeck (2012)). Mas não só. Para Wendy Brown essa mudança implica, é claro, uma nova subjetividade, que resulta da transformação do homo oeconomicus, guiado pelo interesse, em algo de outro tipo, guiado agora pela apreciação do capital (humano).

2) $\mathrm{O}$ crescimento econômico como telos absoluto. A competição foi acirrada pelo processo de financeirização (concorre-se, agora, pelas melhores avaliações das agências de risco, pelo acesso ao crédito fácil e aos juros baixos...), que faz do crescimento econômico um imperativo na gestão macroeconômica. Crescimento baixo "preocupa o mercado", "afasta investidores", "quebra economias". Ninguém pode correr o risco de perder o grau de investimento. É preciso crescer. "Não há alternativa”. 
3) A banalização da crise ou a crise permanente. A criação e o estouro de bolhas econômicas num ritmo cada vez mais acelerado levam o mundo a um estado de crise permanente, produzem uma instabilidade crônica no mundo do trabalho, não só por submeter a oferta de emprego ao fluxo das finanças, mas porque as finanças, ao mostrarem-se mais lucrativas, substituem cada vez mais a produção ${ }^{44}$.

4) Mais austeridade, menos liberdade. As políticas de austeridade como resposta à banalização da crise assumem o lugar da liberdade de empresa, um dos dogmas neoliberais, pelo "sacrifício", essencial para o cumprimento de metas fiscais e para o equilíbrio das contas.

5) Financeirização do Estado. O mercado também participa do jogo do capital financeiro. Emite e negocia títulos, administra fundos de investimento, preocupa-se com a manutenção do grau de investimento e com o valor dos derivativos. Consequentemente, sua margem de manobra também está condicionada aos fluxo das finanças, ao "humor do mercado".

6) Mais governança, menos política. Há uma confusão cada vez maior entre o léxico político e o empresarial e o mesmo vale para as práticas: há uma substituição do império da lei pelos instrumentos de governança, mecanismos que permitem ir da hierarquia à rede, das instituições aos processos, dos comandos à auto-organização, por meio, principalmente, de dispositivos como benchmark, alinhamento estratégico, acompanhamento de indicadores, balanced scorecards (metodologias de gestão de desempenho) e "melhores práticas" (best practices), entre outros.

7) Os sujeitos da governança. Os atores econômicos e as ações econômicas são transformados pela lógica da governança. Conceitos como o de trabalho em equipe, responsabilização e stakeholders substituem a ideia de indivíduos soberanos e livres, que está na base da teoria do interesse, por sujeitos mais explicitamente governados, "responsabilizados", gerenciados.

\footnotetext{
${ }^{44}$ Brown (2015b) aponta que, embora represente apenas 9\% do PIB americano, o setor financeiro corresponde a $30 \%$ de todo lucro corporativo hoje em dia. Antes da crise de 2009, correspondia a $40 \%$. Impossível não pensar aqui no debate brasileiro em torno do BNDES, que na gestão LulaDilma distribuiu dinheiro barato ao empresariado brasileiro, graças à política dos "Campeões Nacionais", mas não obteve o retorno esperado em crescimento econômico, porque em vez investir em tecnologia e infraestrutura, os empresários optaram por aplicar o dinheiro emprestado a juros baixíssimo na bolsa, e auferir lucros altíssimos, com reflexos quase nulos para a economia brasileira.
} 
8) Os investidores de si. A governança coloca num mesmo plano o autoinvestimento e a responsabilização e, dessa forma, integra o capital humano "responsabilizado" ao projeto do crescimento econômico, mitigando, aos poucos, a importância do "interesse" e da liberdade.

9) A autoridade é do outro, a responsabilidade é nossa. Uma das características da governança é combinar o máximo de autoridade (as metas e objetivos são impostos verticalmente), mas as pessoas são cobradas (responsabilizadas) individualmente pela sua realização. O poder é exercido, ao mesmo tempo, de forma massiva e singular.

10) Colinearização ${ }^{45}$. Um dos objetivos de uma boa governança é garantir que o capital humano se identifique completamente com os objetivos da empresa. Essa lógica é replicada no âmbito do Estado, onde o Estado passa a exigir dos cidadãos o máximo de sacrifício em nome da saúde econômica da nação ${ }^{46}$.

11) Grande demais para quebrar, pequeno demais pra proteger. A competição generalizada no mercado financeiro conduz a situações como a da crise de 2008, em que determinados atores são considerados grandes demais para quebrar, pois sua quebra levaria ao colapso da economia, o que "obriga" o estado a resgatá-los (e cobrar a conta dos contribuintes e dos trabalhadores). Outros atores econômicos, no entanto, são considerados pequenos demais para merecerem proteção, por exemplo, pequenos fazendeiros, pequenos comerciantes, famílias e estudantes endividados. O neoliberalismo foi extremamente bemsucedido em desmantelar a rede de proteção do welfare state. Isso não impediu, no entanto, que o Estado continuasse servindo aos interesses de determinados grupos. Sem meias palavras, os interesses do capital.

12) Securitização. Especialmente após o 11 de Setembro, a relação entre a razão neoliberal e a securitização tornou-se mais estreita. Nesse processo, a lei, o princípio democrático e o bem-estar social deram lugar de vez a outras métricas, a saber, a eficácia, o controle e o clima econômico.

A globalização da economia, a integração dos mercados, os avanços tecnológicos que aconteceram entre o período estudado por Foucault (2008) e o

\footnotetext{
${ }^{45} \mathrm{O}$ termo colinearização não é de Wendy Brown, mas de Frederic Lordon (2014), que o utiliza para expressar, numa empresa, a convergência do desejo do empregado com o do patrão: quando o desejo do primeiro se torna o desejo do segundo.

46 "Não pense em crise, trabalhe", já dizia o slogan do, então ainda interino, presidente Michel Temer.
} 
atual momento resultaram numa "complexificação" sem precedentes do cenário econômico mundial, mudando radicalmente as relações entre os Estados e o capital. Ainda que possamos localizar no Estado um grande parceiro do capital - o comitê executivo dos negócios da burguesia, como já alertavam Marx e Engels -, hoje é praticamente impossível distinguir um do outro. As consequências disso para a ideia de democracia são óbvias. Fazer valer a vontade popular, nesse contexto, torna-se cada vez mais difícil. Toda insurreição, toda resistência, toda contra-hegemonia que se queira construir tem que levar em conta esse cenário. Isso vale para o corte populista. Não é simplesmente contra a "institucionalização extrema" que se investe no corte populista: é contra o Capitalismo Mundial Integrado, pra usar a expressão de Felix Guattari (Guattari e Rolnik, 1986), uma imensa máquina que

(...) afirma-se, em modalidades que variam de acordo com o país, através de uma dupla opressão. Primeiro, pela repressão direta do plano econômico e social - o controle da produção de bens e das relações sociais através de meios de coerção material externa e sugestão de conteúdos de significação. A segunda opressão, de igual ou maior intensidade que a primeira, consiste em o CMI instalar-se na própria produção de subjetividade: uma imensa máquina produtiva de uma subjetividade industrializada e nivelada em escala mundial tornou-se dado de base na formação da força coletiva de trabalho e da força de controle social coletivo. (Guattari e Rolnik, 1986, p.39)

Os insights de Guattari, no final dos anos 80 , pareciam ir já um pouco mais longe que os de Foucault na compreensão dos desdobramentos da razão neoliberal, ainda que teorizada em outros termos. Wendy Brown (2015b) faz uma crítica no mínimo interessante à análise foucaltiana do neoliberalismo que, para ela, é "estadocêntrico", porque não é governado por "instituições globais ou transnacionais e constrói relações entre estado, economia e sociedade civil em termos nacionais" (Brown, 2015b, p.72) ${ }^{47}$. Leitura semelhante não poderia ser estendida aqui à análise laclauniana do populismo?

\footnotetext{
${ }^{47}$ Thomas Lemke (2007), autor no qual Wendy Brown (2015a) também se apoia bastante, interpreta os cursos de Foucault sobre o neoliberalismo como o grande movimento do autor francês na direção de uma teoria do Estado. Para Lemke: "A analítica do governo combina a "microfísica do poder (...), que permanecia centrada na questão da disciplina e da normatização, com a questão macropolítica do estado (...). Essa abordagem investiga como relações de poder têm se concentrado historicamente na forma do estado sem nunca serem reduzidas a ele. Seguindo essa linha de investigação, Foucault vê o estado como "nada mais que o efeito móvel de um regime de múltiplas governamentalidades. [...] É necessário aborda-lo de um ponto de vista exterior a questão do estado, é necessário analisar o problema do estado referindo-o às práticas de governo"(...). Quando Foucault foca na "governamentalização do estado" (...) ele não assume que
} 
Parece que sim, pelo menos na medida em que as duas parecem não dar o devido valor à imensa máquina do CMI, que desempenha um papel central na produção da subjetividade neoliberal, num âmbito que transcende o Estado. Subjetividade que não é determinada apenas pelos discursos e práticas, articuladas pelo discurso neoliberal, mas pelas condições materiais objetivas colocadas pelo CMI. É fácil perceber que essa linha de raciocínio parece reintroduzir, via CMI, tanto na análise do neoliberalismo quanto na do populismo, a dinâmica entre infraestrutura, as forças de produção, e superestrutura, o conjunto das instituições ou - para usar a expressão de Lordon (2015), invocada antes - a "armadura institucional do capitalismo", da qual Laclau parece fugir como o diabo da cruz. Grosso modo, é disso mesmo que se trata. Importa, no entanto, garantir que essa relação não seja compreendida, de maneira ortodoxa, como uma relação meramente causal, onde a infraestrutura determina absolutamente a superestrutura. O que se postula aqui é, por um lado, que tal determinação tem caráter contingente e, por outro, que acontece nas duas direções, num movimento de feedback loop - ou de causalidade imanente.

O que autoriza essa abordagem é leitura que Jason Read (2003) faz do uso desse conceito de causalidade imanente por Althusser. Para o autor de Micropolitics of Capital, o solo comum entre Marx e o pós-estruturalismo está na rejeição de qualquer apelo à transcendência e na afirmação da imanência, onde o conceito de causalidade imanente operaria como um mediador entre esses universos. O estrutural, compreendido como causalidade imanente, não separa a causa de seus efeitos, pois essa separação resulta na interpretação de todo efeito como aparência de uma essência que a ela subjaz. A causalidade imanente afirma que não há causa que exista separada de seus efeitos: todos os efeitos são, ao mesmo tempo, causa. Nesse sentido, a estrutura é imanente aos seus efeitos: consiste na totalidade dos efeitos, é uma combinação de seus elementos.

Se tudo é imanente, tanto causa quanto efeito, então não é mais possível entender a estrutura, as ideias e a produção de consciências, como um simples efeito

\footnotetext{
o governo é uma técnica que pode ser aplicada ou usada pelas autoridades do estado ou pelo aparato; em vez disso ele entende o próprio estado como uma forma dinâmica e contingente de relações de poderes sociais. Portanto, a governamentalidade é ao mesmo tempo interna e externa ao estado, uma vez que é a tática do governo que torna possível a continua definição e redefinição do que está dentro da competência do estado e o que não está, o público versus o privado, e por aí vai; ou seja, o estado só pode ser compreendido em sua sobrevivência e em seus limites com base na tática geral de governamentalidade" (Lemke, 2007, 17-18)
} 
emanando do, ou refletindo, o conflito entre forças e relações de produção. Eles devem ser entendidos como causas bem como as condições constitutivas da produção e da dissolução de uma economia particular, ou modo de produção. Não há uma economia pura e simples que é transformada e alterada por diferentes culturas e sistemas de crença; existe apenas um modo de produção, sempre condicionado e determinado por uma produção de subjetividade particular. (Read, 2013, p.9).

Da perspectiva da causalidade imanente, a materialidade do "modo de subjetivação" surge em paralelo com o modo de produção, está no modo de produção. Não se trata de uma soma de "infra" e "superestrutura", que funcionariam como um complemento ou suplemento de historicidade: é uma combinação de duas "bases" explicativas, duas determinações ao mesmo tempo incompatíveis e indissociáveis: a ideológica e a econômica. Economia e ideologia não têm, em si mesmas, histórias próprias, na medida em que cada uma só encontra sua história através da outra, que é causa eficiente de seus efeitos.

No modo de produção capitalista, a atividade produtiva está subordinada à reprodução social (um modo de vida e uma estrutura de subjetividade específicos).

O modo de produção capitalista é ele mesmo baseado no "potencial subjetivo abstrato", a capacidade de fazer qualquer trabalho, seja ele qual for, o qual deve simultaneamente desenvolver, por meio da disciplina e da cooperação, e conter, por meio da disciplina e das várias técnicas de subjetivação. (Read, 2013, p.10)

Read argumenta que isso continuará sendo válido para o que Marx chama de subsunção formal, que as formas primitivas do capitalismo tornaram possível pela imposição do trabalho assalariado. No modo de produção que Marx caracteriza como especificamente capitalista, a subjetividade deixa de ser reproduzida, mas se torna produtiva; e produtiva não como potencialidade abstrata, mas na forma de conhecimento, desejo e afeto. Seguindo esse trajeto teórico, acredita Read, é possível trazer Marx para o centro do debate contemporâneo.

Read leva a sério a advertência de Balibar, para quem a relação entre subjetividade e produção num dado modo de produção não deve ser encarada de modo funcionalista. Não é que o capital, ou qualquer outro modo de produção, produza toda subjetividade de que precisa em um gesto infinito de autorreprodução - o que acontece na leitura economicista de Marx -, de modo que toda forma de antagonismo estaria simplesmente a serviço da reprodução do 
sistema. A produção de subjetividade sempre excede ou fica aquém das demandas do modo de produção. As crenças e desejos que constituem a subjetividade são condições para a transformação na produção ocasionadas pela mercantilização do conhecimento, do desejo e da sexualidade pelo próprio capital. Para Read (2013), ainda estamos às voltas com a tese do Manifesto Comunista de que o capitalismo cria seus próprios coveiros. O autor acredita que a oposição irreconciliável entre essas duas esferas - subjetividade e capital (cultura e economia) - só é possível ante a ignorância da causalidade imanente na obra de Althusser. Algo que repercute, por exemplo, na interpretação de Deleuze \& Guattari sobre imanência do desejo a todas as relações sociais; e nas teses de Foucault sobre imanência do poder à subjetividade e ao conhecimento. Esses autores, acredita Read, herdaram não apenas o legado intelectual, mas o problema de Althusser, que continua mais atual do que nunca: o de "pensar a resistência quando, como argumentou Frederic Jameson, aquelas últimas reservas de transcendência, natureza e inconsciente, foram perfeitamente mercantilizadas e exploradas (Read, 2013, p.11).

É dessa perspectiva de uma causalidade imanente que se torna possível uma leitura espinosista da dimensão afetiva do populismo e uma especulação em torno do seu uso como forma de organização política, bem como de sua eficácia como tal. 


\title{
4
}

\section{Afeto e relacionismo radical em Espinosa}

\author{
"The search for lucidity and \\ disillusionment may never attain a final \\ goal or provide more than partial \\ emancipation; yet it will always accept \\ the immanent world, with its finitude \\ and inherent uncertainties, as the \\ overall domain of being and value, \\ neither hell, nor paradise but man's \\ metaphysical homeland, a creative, \\ even joyful vale of tears where \\ suffering and perseverance, finitude \\ and autonomy inform one another" \\ Yirmiyahu Yovel
}

Neste capítulo, a questão do afeto será abordada a partir de algumas leituras contemporâneas do pensamento de Espinosa, principalmente as de Vittorio Morfino e Fréderic Lordon. O objetivo é mostrar de que modo o "paralelismo" da relação entre mente (pensamento) e corpo (extensão) no sistema espinosano nos permite pensar os afetos como produtos de afecções que acontecem no tempo e no espaço.

No subcapítulo 4.1 acompanha-se a descrição de Althusser para o gesto espinosano de colocar a reflexão sobre Deus no princípio da Ética, invertendo o processo filosófico que, até então, partia do sujeito (ou do cogito), para chegar a Deus. Discute-se, também, de que modo a equivalência de Deus à natureza coloca a ideia de imanência no centro da filosofia de Espinosa. Procura-se esclarecer, ainda, o que leva Morfino a afirmar que a filosofia de Espinosa, a despeito de desenvolver-se a partir da ideia de uma substância única, pode ser compreendida como uma ontologia da relação, ou um relacionismo radical. No subcapítulo 4.2, discute-se de que modo os afetos ocupam, nessa ontologia da relação, um lugar privilegiado, e o modo como isso produz uma concepção muito particular de 
indivíduo. No subcapítulo 4.3, exploram-se algumas das implicações políticas dessa concepção de indivíduo e afeto em Espinosa.

No subcapítulo 4.4, o populismo volta à baila, para ser pensado, agora, a partir das ferramentas conceituais que Espinosa oferece. No 4.5, procura-se mostrar como a noção de ingenium ajuda a responder, de uma perspectiva espinosista, uma pergunta repetida à exaustão nos capítulos anteriores: porque um discurso populista "cola"? No subcapítulo 4.6, procura-se utilizar os conceitos articulados ao longo da dissertação face alguns fenômenos políticos contemporâneos.

\section{1}

\section{O relacionismo radical e o atravessamento das paixões}

Uma leitura precipitada de Espinosa poderia levar muita gente a questionar a validade do sistema da Ética para a compreensão dos problemas contemporâneos, bem como a considerar uma grande bobagem a pretensão de considerar sua teoria dos afetos um complemento da abordagem psicanalítica dessa questão. Afinal, trata-se do livro que pretende explicar o mundo começando por nada mais nada menos do que Deus, recorrendo para isso a uma série de expressões oriundas do pensamento escolástico.

Para compreender a centralidade do afeto na filosofia de Espinosa é preciso compreender, primeiro, o substrato metafísico do sistema espinosano, que se desdobra todo a partir do ponto de partida escolhido por ele: Deus. O conceito de imanência, nesse sistema filosófico (ou ético), é um produto da fórmula Deus sive natura, largamente utilizada para sintetizar o gesto filosófico empreendido na Ética, onde a primazia conferida por Espinosa à substância única revela-se, no fim das contas, um golpe fatal no substancialismo que caracterizava a metafísica escolástica.

De maneira geral, a Ética é de longe o texto mais puramente filosófico que Espinosa escreveu, e o mais unívoco. Ainda assim, Espinosa não fala para si mesmo nele. Ele claramente leva sua audiência em consideração em seu ponto de partida. Por exemplo, as primeiras onze proposições são direcionadas aos proponentes da Nova Filosofia num esforço tácito - polêmico e didático - para afastá-los de Descartes em favor da posição espinosista. Sem essa intenção, Espinosa poderia ter começado sua dedução de outra maneira. Além disso, o 
método geométrico tem em si mesmo uma função retórica sutil em Espinosa, assim como tem sua escolha por termos teológicos tradicionais. (Yovel, 1989, p.137)

É sobretudo por conta desse gesto - ou desse golpe - teórico de Espinosa que Louis Althusser, num de seus textos mais conhecidos (e possivelmente dos mais esotéricos) identifica no pensador um dos expoentes do que chama de "corrente subterrânea do materialismo do encontro", uma linha tênue, praticamente invisível, que perpassaria, no entender desse autor, a história da filosofia, de Epicuro a Marx, passando por Maquiavel, Hobbes, Rousseau, Heidegger e Marx, incluindo ainda filósofos contemporâneos de Althusser, como Deleuze e Wittgenstein. No texto, Espinosa aparece ao lado desses pensadores como um daqueles que teria feito do "vazio" o objeto de sua filosofia, algo que ele identifica precisamente na decisão de tomar Deus como ponto de partida da Ética, invertendo tanto a ordem estabelecida pela tradição escolástica, que mandava começar pelo mundo para chegar a Deus, quando o método, que chegava igualmente a Deus, começando pelo sujeito pensante, o cogito. "Todos passam por Deus. Espinosa se poupa deste rodeio e se instala deliberadamente em Deus" (Althusser, 2005, p.15), para além do qual não há nada, simplesmente porque Deus, na fórmula espinosana, é absolutamente tudo que é e tudo que pode vir a ser. É nessa equivalência de Deus ao Todo, à totalidade de todas as coisas, que Althusser identifica o vazio, no centro do espinosismo:

\footnotetext{
Dizer "eu começo por Deus", ou pelo Todo, ou pela substância única, e deixar entender "eu não começo por nada", é, no fundo, a mesma coisa: que diferença haveria entre o Todo e o nada? Dado que nada existe fora do Todo... De fato, o que há a dizer de Deus? É aqui que começa a estranheza. Deus não é mais do que natureza, o que equivale a dizer nada diferente de: ele é unicamente natureza. (Althusser, 2005, p.15).
}

Substância única, absoluta, infinita, dotada de infinitos atributos, dois quais só conhecemos dois, pensamento e extensão, nous e physis num "paralelismo" em que toda modificação se expressa ao mesmo tempo num atributo e no outro. Totalização, redução de tudo à univocidade do ser: um fechamento ontológico que coloca o pensamento diante do infinito. Deus, apreendido em sua imensidão, em sua infinitude, não como ponto de chegada - o ponto de luz para onde todo pensamento converge -, mas como ponto de partida: escuridão explorada com o auxílio da "luz natural" da razão. Dos atributos infinitos desse Deus, só 
conhecemos dois - e de maneira parcial: "não conhecemos as potências do corpo, assim como não conhecemos, do pensamento, a potência impensada do desejo" (Althusser, 2005, p.16). Os demais atributos - infinitos - abarcam o possível e o impossível. "Que sejam em número infinito e que nos sejam desconhecidos, deixa bem aberta a porta para sua existência e para suas figuras aleatórias" (Althusser, 2005, p.16).

Quais os efeitos filosóficos dessa estratégia? - pergunta-se Althusser. É que, depois disso, não apenas não resta mais nada a dizer de Deus, como não resta mais nada a dizer do "problema do conhecimento e seu duplo correlato, o sujeito cognoscente e o objeto conhecido" (Althusser, 2005, p.17). O problema do conhecimento torna-se um "pseudoproblema". O homem pensa. Ponto. É fato. $\mathrm{Ou}$, como diria Heidegger, "es gibt". E esse pensamento constitui o homem, basta, para isso, que "pegue", que passe pelos pensamentos confusos e pelos rumores da imaginação - que constitui o que Espinosa chama de conhecimento de primeiro gênero - até chegar às "noções comuns" - segundo gênero do conhecimento - para daí trilhar o caminho até as essências singulares, o conhecimento de terceiro gênero - ou o caminho do sábio, que conduz à beatitude. $\mathrm{Ou} n \tilde{a} o^{48}$. O terceiro gênero do conhecimento não é onde devemos chegar, mas onde podemos. No espinosismo não há Deus, nem telos (psicológico ou histórico), apenas "o vazio que é a filosofia mesma" (Althusser, 2005). Como primeiro gênero do conhecimento, a imaginação, para Espinosa, não corresponde a uma faculdade, como aponta Althusser, mas é "no fundo, somente o único e mesmo mundo, no seu dado" (Althusser, 2005, p.18). Com tudo mais, a imaginação é em Deus - ou na natureza: imanente, como tudo mais.

Através deste deslizamento, Espinosa não só escapa de qualquer teoria do conhecimento, mas abre a via para o reconhecimento do "mundo" como aquilo além do qual nada existe, nem sequer uma teoria da natureza. Ele possibilita o reconhecimento do "mundo" como [...] totalidade única não totalizada mas vivida na sua dispersão, e vivida como o "dado" no qual somos "jogados" e a partir do qual forjamos todas nossas ilusões ("fabricae"). (Althusser, 2005, p.18)

\footnotetext{
48 "Essa é a sorte da maioria das pessoas que ficam no primeiro gênero e no imaginário, quer dizer, na ilusão de pensar, embora elas não pensem. É assim. Pode-se ficar no primeiro gênero ou podese não ficar nele. Não há, como em Descartes, uma necessidade imanente que faça passar do pensamento confuso ao pensamento claro e distinto, não há cogito, não há qualquer momento necessário de reflexão que assegure esta passagem. Pode acontecer ou não. E a experiência mostra que em regra geral não acontece, salvo na exceção de uma filosofia consciente de não ser nada." (Althusser, 2005, p.17)
} 
Essa concepção da imaginação, como via de acesso ao "mundo" responde, para Althusser, à imagem de Deus como natureza, que se nos apresenta como "o mundo pensado segundo as noções comuns, mas dado antes dela como aquilo além do que nada há" (Althusser, 2005, p.18). Trata-se de um gesto rápido, mas extremamente potente - como são igualmente rápidos e potentes outros gestos filosóficos de Althusser nesse texto - que, para o francês, coloca o pensamento filosófico de Espinosa e o pensamento político de Maquiavel num mesmo plano, porque: "É no imaginário do mundo e de seus mitos necessários que se (...) exerce a política de Espinosa" (Althusser 2005, 18, grifo meu). Não é por acaso - como de resto, quase nada é, nesse texto - que o pensador que antecede Espinosa na exploração althusseriana da corrente subterrânea do materialismo do encontro seja o "agudíssimo florentino", como foi chamado por Espinosa, no Tratado Político, o autor de $O$ Príncipe. Juntos, esses pensadores investiram, afirma Althusser, contra "todos os pressupostos da filosofia tradicional" (Althusser, 2005, p.18). Para eles, "a autonomia do político não é mais do que a forma adotada pela exclusão de qualquer finalidade, de qualquer religião e de qualquer transcendência" (Althusser, 2005, p.18). Se as noções comuns emergem da "carambolagem" - do choque que espalha bolhas de bilhar numa mesa de sinuca das vastas emoções e pensamentos imperfeitos que constituem a imaginação, a essência singular, ou ingenium, de um indivíduo ou de um povo, se constitui necessariamente como história. E, importa destacar: "Que seja necessária significa unicamente que ela se consumou" (Althusser, 2005, p.18).

Essa maneira muito particular que Espinosa tem de se apropriar dos termos escolásticos, desconstruí-los e subvertê-los para construir seu próprio sistema filosófico é um dos aspectos que Morfino explora, indiretamente, para defender a hipótese da teoria espinosista como uma ontologia da relação. Morfino toma como referência o seu conterrâneo Enzo Paci. Segundo Paci, uma coisa considerada individualmente nunca é uma substância “imóvel e fechada em si mesmo... mas, em vez disso, é um complexo de processos, de eventos mais ou menos organizado" (Paci apud Morfino, 2014, p.57). Três critérios separam o relacionismo do idealismo no entender do italiano: o relacionismo

1) exclui a identidade fechada do universo; 2) enquanto o universo fechado e idêntico identifica cada momento com o todo, de maneira que nenhum momento é discernível, o relacionismo determina os nós das relações universais como momentos distintos e os atualiza em situações existenciais; 3) o relacionismo 
insiste na inexaustibilidade das relações... uma relacionalidade sempre aberta. (Paci apud Morfino, 2014, p.57)

Paci, aponta Morfino, opõe sua filosofia da relação precisamente ao que denomina filosofias da substância, nas quais a substância é entendida como aquilo que é em si mesma e por si mesma e de nada mais precisa para existir, o que coincide, a princípio, com a definição espinosana. Para esse autor, diferentemente do que acontece no substancialismo, no relacionismo só existe o evento, que existe para um outro e em relação com um outro. Nesse ponto, ele coloca Aristóteles e Espinosa num mesmo plano, o da metafísica da substância. O que Morfino se propõe a fazer é tirar "o príncipe dos filósofos" da companhia do estagirita. Ele começa assim:

O gesto teórico sem precedentes da Parte Um da Ética é essa apresentação da substância infinita como a única in se esse. Mas esse mesmo gesto produz uma importante consequência: as coisas singulares são agora conhecidas como modos, ou seja, como esse in alio. O modo entendido como id quod in alio est é precisamente o que Paci chama de "evento"; os modos são sempre em e para alguma outra coisa. A substância espinosista, por sua vez, não é nada mais que a estrutura imanente dessa referencia a alguma outra coisa - não é de maneira alguma uma substância permanente às quais as substâncias inerem. (Morfino, 2014, p.58)

Segundo Paci, portanto, o relacionismo radical é o primado da relação sobre a substância. O que o relacionismo determina não é o todo, mas os nós das relações universais, compreendidos como momentos espaço-temporais distintos e atualizados como situações existentes, discerníveis umas das outras. A pergunta que Morfino procura responder é a seguinte: é possível compreender a filosofia de Espinosa dessa perspectiva? Dá para reconhecer no espinosismo uma ontologia da relação?

Morfino dá início à sua investigação procurando referências ao conceito de relação na obra de Espinosa. Uma delas, ele diz, aparece nos Pensamentos Metafísicos, outra no Breve Tratado. Na Ética a palavra aparece 17 vezes, mas sem nenhuma definição. Em E3Daf48, a expressão é usada em sentido técnico, como denominação extrínseca. Em outra parte, no entanto, há o uso da fórmula denominação intrínseca, associada às propriedades ${ }^{49}$, o que permite a Morfino

\footnotetext{
49 "Por ideia adequada compreendo uma ideia que, enquanto considerada em si mesma, sem relação com o objeto, tem todas as propriedades ou denominações intrínsecas de uma ideia verdadeira." (E2D4, 79)
} 
inferir que Espinosa separa "as características que constituem a essência de cada coisa daquelas que dependem da interação da coisa com alguma outra coisa: ou seja, ele claramente separa proprietates de relaciones" (Morfino, 2014, p.59). No Tratado da Emenda do Intelecto, Morfino encontra algumas pistas que podem ajudar na compreensão da concepção espinosana de relação. Nele, Espinosa afirma que para reproduzir a ordem da natureza é necessário conhecer a série "por meio da qual as coisas se concatenam segundum seriem causarum" (Morfino, 2014, 60).

As distinções de Espinosa nos autorizam a dizer que o conceito de "propriedade" está amarrado à interioridade de uma essência, enquanto o conceito de "relação" está ligado à exterioridade da existência. Em outras palavras, isso nos permite dizer que há um plano ontológico onde as coisas são ordenadas por propriedades essenciais (e por relações lógicas exclusivas entre essas propriedades) e outro plano onde essa ordem é perturbada por relações e circunstâncias existenciais. Essa é, aparentemente, a estrutura ontológica dentro da qual encontramos o único uso técnico da palavra relatio na Ética". (Morfino, 2014, p.60)

Morfino confronta essa interpretação extraída do Tratado à totalidade da Ética e identifica três problemas: (1) a ética proíbe distinção de nível entre coisas fixas e eternas e coisas singulares e mutáveis; (2) nela, o termo "série" é substituído por "conexão"; (3) e nela Espinosa nunca fala em essentia intima, mas em actuosa essentia, além de identificar a essência à potência.

Para Morfino, essas diferenças são consequências do gesto teórico que faz de Deus não apenas causa primeira, mas causa imanente de todas as coisas. A ideia de causalidade finita concebida como série deixa de fazer sentido, uma vez que, pensada como connexio a coisa singular, ou o indivíduo, perde sua simplicidade, sua unidade. O que antes era visto como coisa singular, agora o é como complexidade ou, em termos neoplatônicos, como "complicação" (complicatio). Nessa relação, não há distinção entre essência e potência: a essência é precisamente a capacidade que a coisa singular tem de entrar numa relação com o que lhe é exterior e tão mais poderoso é o indivíduo quanto mais complexas são as relações que ele é capaz de estabelecer. "Cada causa não tem mais a forma de uma imputação jurídica e se torna, em vez disso, uma pluralidade de relações complexas com o fora" (Morfino, 2014, p.61).

Com o conceito de causalidade imanente, apresentado na Ética, Espinosa elimina a barreira entre o dentro e o fora e o que passa a regular a relação entre 
interior e exterior é agora a potência ${ }^{50}$. "A variedade das coisas não é dedutível da extensão a priori, pois a essência das coisas reais é construída na e pelas relações e conexões" (Morfino, 2014, p.62). Essa é uma consequência da teoria das paixões em Espinosa. Pensados segundo a ordem geométrica - como planos, linhas e corpos - os afetos emergem como propriedades da natureza humana, constituem sua essência. A compreensão dos afetos primários é importante para compreender essa construção.

\title{
4.2 \\ Os afetos primários
}

$\mathrm{Na}$ Ética de Espinosa, desejo, alegria e tristeza são variações que constituem a interioridade. O desejo (cupiditas), para Espinosa, é um apetite (appetitus) consciente dele mesmo, que emerge como uma expressão do conatus, palavra que traduz, na linguagem espinosana, o esforço para perseverar no ser. Dito de outra forma, a luta para manter a relação entre movimento e repouso das partes que constituem um corpo ${ }^{51}$.

\begin{abstract}
Esse esforço, à medida em que está referido apenas à mente, chama-se vontade; mas à medida que está referido simultaneamente à mente e ao corpo chama-se apetite, o qual, portanto, nada mais é do que a própria essência do homem, de cuja natureza necessariamente se seguem aquelas coisas que servem para a sua conservação, e as quais o homem está, assim, determinado a realizar. Além disso, entre apetite e desejo não há nenhuma diferença, excetuando-se que, comumente, refere-se o desejo aos homens à medida que estão conscientes de seu apetite. Podese fornecer, assim, a seguinte definição: o desejo é o apetite juntamente com a consciência que dele se tem. Torna-se, assim, evidente, por tudo isso, que não é porque julgamos uma coisa boa que nos esforçamos por ela, que a queremos, que a apetecemos, que a desejamos, mas, ao contrário, é por nos esforçarmos por ela, por querê-la, por apetecê-la, por desejá-la, que a julgamos boa. (E39Esc, p.177)
\end{abstract}

Os afetos de alegria e de tristeza são expressões mentais de variações de grau nessa relação entre movimento e repouso que constitui o corpo; o primeiro, no sentido de um equilíbrio mais perfeito entre as partes, e num aumento da potência de agir; o segundo, no de um equilíbrio menos perfeito, e em uma potência de agir menor.

\footnotetext{
${ }^{50} \mathrm{O}$ gesto espinosano remete à abertura das monadas leibnizianas por Gabriel Tarde. No caso nas monadas tardianas, a relação entre o interior e o exterior é regulada por crença e desejo.

51 "Os corpos se distinguem em razão do movimento e do repouso, da rapidez e da lentidão e não em relação à substância." (E2L1)
} 
Vemos, assim, que a mente pode padecer grandes mudanças, passando ora a uma perfeição maior, ora a uma menor, paixões essas que nos explicam os afetos da alegria e da tristeza. Assim, por alegria compreenderei, daqui por diante, uma paixão pela qual a mente passa a uma perfeição maior. Por tristeza, em troca, compreenderei uma paixão pela qual a mente passa a uma perfeição menor. Além disso, chamo o afeto da alegria, quando está referido simultaneamente à mente e ao corpo, de excitação ou contentamento; o da tristeza, em troca, chamo de dor ou melancolia. Deve-se observar, entretanto, que a excitação e a dor estão referidas ao homem enquanto uma de suas partes é mais afetada do que as restantes; o contentamento e a melancolia, por outro lado, quando todas as suas partes são igualmente afetadas. (E3P11Esc, p.177-9)

Um aspecto fundamental pra compreender a dinâmica dos afetos primários é saber que eles só se modificam numa relação com o exterior. Como aponta Frédéric Lordon (2015), o desejo opera, para Espinosa, como força motriz dos comportamentos individuais e os afetos como causas de primeira instância, causas que determinam a direção do desejo. Lordon identifica no conatus uma "força de atividade genérica e intransitiva" (Lordon, 2015, p.64). É uma força sem objeto. É diante de uma afecção que essa força encontra as orientações concretas que a determinam, de modo que, só então, o desejo - enquanto apetite consciente de si torna-se desejo disto ou daquilo. O afeto, por sua vez, resulta das afecções.

Daí a importância da atenção dada por Deleuze e Guattari à distinção entre afecção e afeto. Como aponta John Protevi (2009), para a dupla tal distinção é central na tentativa de definir o que é um corpo - primeiro passo para tentar responder a uma das perguntas fundamentais de Espinosa: o que pode um corpo? Para os autores, o que define um corpo é sua potencia ativa de agir sobre outros corpos (de afetá-los), bem como sua potência passiva de sofrer as ações de outros corpos (ser afetado). A distinção entre afeto (affectus) e afecção (affectio) é esclarecedora. Conforme a definição espinosana, por afeto, os autores compreendem essa experiência de aumento ou dominuição da potência de agir de um corpo, conforme descrito acima, nos exemplos da alegria e da tristeza; por afecção, compreendem o resultado da composição, da mistura dos corpos compostos igualmente de um sem número de corpos menores - em decorrência de um encontro. $\mathrm{O}$ afeto, para esses autores, não é uma representação (como seria se estivéssemos falando de sentimentos, por exemplo), mas a experiência de uma mudança de grau entre dois estados, mais precisamente, um aumento ou uma diminuição na potência de agir de um corpo. Trata-se de uma experiência puramente transitiva. A afecção, por sua vez, diz respeito à mudança nas relações 
extensivas de um corpo, ou, em termos espinosistas, à mudança na relação entre movimento e repouso entre as partes que o constituem - mudança essa que é sempre motivada por um encontro com outros corpos ${ }^{52}$.

Retomando aqui a linha de raciocínio iniciada com referência anterior a Lordon: é no contato com o exterior que o conatus se torna apetite e o apetite se torna desejo de alguma coisa (ou e alguém): é só na relação de um interior (interior de um corpo capaz de ser afetado) com o que lhe é exterior (outros corpos capazes de afetar) que o desejar se torna um verbo transitivo. São as afecções e os afetos que dela se seguem que tiram um corpo de seu estado de repouso e o põem em movimento: "um corpo em movimento é um corpo desejante, isto é, um corpo que foi determinado a desejar os fins imaginados do movimento" (Lordon, 2015, p.64, grifo nosso)

Esse é um aspecto fundamental para a interpretação de Morfino. Nem substância, nem sujeito: o indivíduo emerge como uma relação entre um "exterior e um interior constituído por essa mesma relação" (Morfino, 2014, p.63). É na relação que o indivíduo emerge como actuosa essentia em Espinosa. O que, a rigor, Espinosa define como essência é precisamente o que, autores mais recentes, como Gilbert Simondon, chamam de transindividual ou individuação transindividual. Como aponta Jason Read (2016), a partir dessa definição do desejo como "a própria essência do homem" (E3Daf3, p.237), Espinosa desdobra uma série de proposições que conduzem a uma concepção de humanidade como resultado de uma relação. Relação, em primeiro lugar, com o corpo. Isso porque, para Espinosa: "O que, primeiramente, constitui o ser atual da mente humana não é senão a ideia de uma coisa singular que existente em ato" (E2P11), a saber, o corpo, essa relação particular que se define, como já foi dito acima, como uma capacidade de afetar e ser afetado.

O corpo está constantemente passando por transformação, aumentando e diminuindo sua capacidade de agir, e ganhando e perdendo suas dimensões componentes. Essas transformações são correspondidas no lado do pensamento,

\footnotetext{
${ }^{52}$ Em Mil Platôs: capitalismo e esquizofrenia, os autores descrevem essa alteração promovida pela afecção como uma mudança de "longitude", já àquela representada pelo afeto - aumento ou diminuição da potência de agir - os autores descrevem como uma mudança de "latitude" (Protevi, 2011b). Na mesma obra, o afeto é inscrito na ordem do devir e associado à capacidade de um corpo para compor com outros corpos e produzir agenciamentos. Os afetos que emergem de um encontro podem tanto compor com um corpo, ou chocar-se contra ele. No primeiro caso, o de um encontro feliz, ocorre um aumento da potência de agir.
} 
que está constantemente refletindo e agindo sobre essas transformações, conforme as ideias vão sendo moldadas por (e moldando) esses encontros e aumentos e diminuições na potência. A essência de um dado indivíduo não é uma substância, ou uma forma; não é nada mais do que o esforço, a consciência, o desejo de preservar uma relação particular, nessa miríade de transformações. (Read, 2016, p.27)

Para Morfino, no entanto, nem mesmo a ideia de uma relação transitiva dá conta desse processo. Isso porque a causalidade imanente implica, para Espinosa, um nexo causal infinito: "todo efeito individual é sempre já sobredeterminado por outros afetos" (Morfino, 2014, p.64). As paixões não são, portanto, propriedades da espécie humana ou da natureza humana, não é disso que se trata a essência. Para tornar mais claro seu ponto de vista, Morfino recorre à tradução do italiano Paolo Cristofolini, na qual a expressão latina passionibus obnoxius, utilizada por Espinosa, se transforma no attraversati dalle passioni - o atravessamento das paixões. Como explica Morfino, essa expressão é, em geral, traduzida por termos como "subjugado" ou "submetido" às paixões. Morfino as considera inadequadas, porque, no seu entender, o texto de Espinosa não diz que somos escravos das paixões, mas que somos atravessados por elas. É uma diferença importante. O afeto não é algo que acontece no indivíduo, mas entre indivíduos. É, portanto, transindividual. Tem nas circunstâncias sua origem. Embora sejam afetos primários em relação ao indivíduo, desejo, alegria/prazer (aumento de potência) e tristeza/dor (diminuição de potência) não são primários do ponto de vista da causalidade imanente, porque nela o indivíduo não passa de uma conexão singular: o nó de sua infinita rede causal. Morfino enumera dez exemplos, a partir de Espinosa, que podem influenciar na constituição dessa conexão singular que resulta de um encontro. Abaixo, esses exemplos serão reunidos e classificados:

1) A memória de um afeto - A memória de outros afetos e emoções que resultaram, no passado, de um determinado encontro e que agora associamos a um outro.

2) A semelhança entre objetos da afecção - A semelhança de um objeto exterior com alguma coisa ou objeto pelo qual fomos afetados em outro momento.

3) A emulação de um afeto - A maneira como a emoção sentida por outra pessoa também nos afeta. 
4) $\mathrm{O}$ afeto indireto $-\mathrm{O}$ sentimento que nutrimos por outra pessoa, $\mathrm{o}$ que nos leva a ser indiretamente afetados por aquilo que a afeta, por exemplo, a inveja.

5) $\mathrm{O}$ afeto espelho - $\mathrm{A}$ emoção que nutrimos por alguém que é parecido conosco, por exemplo, identificação, a compaixão, identificação, benevolência.

6) O olho do outro - O sentimento de aprovação de outros homens, por exemplo, a glória, a vergonha, o pudor;

7) Desejo pelo outro - $\mathrm{O}$ sentimento que nutrimos por alguém, por exemplo, o amor, a lascívia.

8) $\mathrm{O}$ desejo do outro - $\mathrm{O}$ sentimento que alguém nutre por nós, por exemplo, o reconhecimento, a gratidão, o amor.

9) Desejo do desejo do outro - O sentimento que alguém, por quem nutrimos algum sentimento, nutre por outro, por exemplo, o ciúme, a inveja. 10) $\mathrm{O}$ desejo de um afeto coletivo - $\mathrm{O}$ sentimento experimentado pelos que pertencem a uma classe ou nação com a qual estabelecemos contato e fomos afetados em determinada oportunidade, por exemplo, o patriotismo, como amor à pátria, a xenofobia, como ódio ao estrangeiro.

Para Morfino, é o atravessamento das paixões que produz em nós estado de flutuação do ânimo (fluctuatio animi). Somos empurrados ou arrastados por forças opostas ao sabor dos encontros, como um barco à deriva num mar revolto. Para Morfino, da perspectiva da causalidade imanente, numa ontologia da relação essa flutuação do ânimo equivale precisamente à psique, constituída pelo nexo causal, pelo atravessamento das paixões faz de nós coisas singulares. Nessa ontologia da relação não há lugar para a substância: afetos secundários ou afetos compostos são, por assim dizer, os verdadeiros afetos, resultantes da relação dos afetos primários (desejo, alegria e tristeza) com o exterior: os afetos primários operam, nessa ontologia, como noções comuns ou operadores conceituais que nos dão acesso aos afetos compostos ${ }^{53}$. Quando Espinosa se refere às relações como entes

\footnotetext{
${ }^{53}$ No âmbito desta dissertação, importa sinalizar que essa abordagem de Morfino poderia apresentar-se como um caminho para aproximar um pouco essa concepção de afeto, em Espinosa, daquela da jouissance, em Lacan, que foi abordada, aqui, no segundo capítulo. Vimos que, para Lacan, a jouissance não pode ser reduzida a um processo natural. O mesmo se aplica ao afeto, dessa perspectiva do atravessamento das paixões, na medida em que, por um lado, ele se manifesta sempre como fluxo de um nexo causal infinito que não podemos apreender imediatamente. Se acompanhamos a argumentação de Stavrakakis, quando afirma que a questão da linguagem perdeu
} 
de razão (entia rationis), esclarece Morfino, se refere a eventos singulares que elas constituem no plano da causalidade imanente,

Relações como identidade, diferença, oposição e assim por diante não são mais que entia rationis com uma função precisa: elas nos ajudam a classificar as conexiones singulares que os indivíduos de fato são. Essas classificações têm seu fundamento na imaginação e na memória, não na razão. (Morfino, 2014, p.68)

\section{Entender isso é, para Morfino (2014), essencial para distinguir o sistema} espinosano do hegeliano ou do platônico, que têm nessa recusa de Espinosa à hipóstase desses termos uma diferença fundamental. Para Espinosa, a substância nunca se torna sujeito, a causa sui nunca se torna conceito, "porque sua estrutura é

aos poucos sua importância na teoria lacaniana, tendo sido preteria em relação ao Real que, por meio das tipologias da jouissance, se tornou uma espécie de força bruta, algo equivalente ao Drang da pulsão freudiana, parece que nos aproximamos um pouco da ideia de desejo como expressão do conatus, em Espinosa. Se Stavrakakis estiver correto quando afirma que os seminários tardios de Lacan conferem à jouissance uma prioridade causal sobre o significante, donde a linguagem emerge como um "semblant imaginário" (Stavrakakis, 2007, p.95), parece que não estamos muito distantes também da ideia de causalidade imanente. Trata-se, no entanto, pelo menos para Lacan, de uma causalidade tão complexa que não está ao nosso alcance apreender, por assim dizer, sub specie aeternitatis.

Outro ponto de contato parece encontrar-se no problema da transição do Real ao somático, com o qual Lacan parece estar às voltas, quando de ocupa da dinâmica RSI (Real-SimbólicoImaginário). À primeira vista, isso não parece uma questão que preocupa Espinosa, pois ele parece tirá-la do caminho por meio do paralelismo: mente e corpo, para Espinosa, operam em uníssono. Dizer que elas operam em uníssono, no entanto, não é o mesmo que dizer que funcionam da mesma forma, que funcionam de maneira idêntica. Isso porque as modificações sofridas por um corpo, em decorrência de um encontro, obedecem à lógica que rege as transformações no atributo da extensão; em decorrência do mesmo encontro, modificações acontecem simultaneamente, em uníssono, em paralelo, na mente, mas segundo a lógica que rege as transformações no atributo do pensamento. Nem sempre é possível apreender conscientemente, e formar uma ideia adequada, das transformações produzidas no pensamento decorrência de um encontro. Às vezes, tudo que resta de "pensável" num encontro são traços. O que não tem lugar no sistema espinosista, no entanto, é a ideia de inconsciente.

Essa aproximação entre as concepções de afeto em Lacan e Espinosa, é preciso reconhecer, é, no mínimo, problemática. É bem possível que fosse rejeitada veementemente por Lacan. $\mathrm{O}$ máximo que se pode fazer, nos limites deste trabalho, é apontá-la. Como nota Jeremy Gilbert (2014), algo nesse sentido é proposto por Teresa Brennan, que "oferece uma teorização desafiadora da 'transmissão do afeto', que ela compreende a transmissibilidade do afeto - o fato de, colocando de modo simples, o humor de uma pessoa pode aparentemente afetar outra diretamente - como evidência de sua tese geral, de que o indivíduo autocontido é um mito, um produto da ideologia burguesa (...). Os principais recursos teóricos para essa tese são encontrados, talvez surpreendentemente, na psicanálise neofreudiana de Jacques Lacan, que ela interpreta argumentando que uma forma individualizada de subjetividade é algo específico da cultura capitalista moderna e não uma invariante histórica. É infelizmente necessário notar que Brennan desdenha completamente o fato de que é mais ou menos isso que Deleuze e Guattari fazem em seu Anti-Édipo. A questão sobre o quanto as teorias de Lacan conflitam ou não com as de Deleuze e Guattari é altamente polêmica, embora alguns poucos seguidores de ambos os campos tenham acreditado que ela é compatível; e pelo mesmo motivo, a leitura de Brennan para Lacan não foi muito influente. De todo modo, sua investigação demonstra que a abordagem da esquizoanálise não é a única a partir da qual as mesmas conclusões básicas podem ser extraídas: nomeadamente, que relações laterais, horizontais de afetividade são constitutivas tanto social quanto subjetivamente, e que a aceitação dessa verdade deve minar todo individualismo simplista" (Gilbert, 2014, p.150) . 
ab origine a-conceitual" (Morfino, 2014, p.69). Trata-se, como diria Althusser, de "uma totalidade sem fechamento" (Morfino, 2014, p.69). São relações que constituem tanto o indivíduo, sua autoimagem e sua imagem do mundo, quanto a sociedade: relações que a ambos precedem. O social está, portanto, sempre dado de antemão. O indivíduo não preexiste às relações passionais, mas é, a priori, socializado por elas.

O que estamos chamando de "ontologia da relação" só pode portanto ser chamado de "ontologia" sob a condição de que façamos uma modificação radical no sentido tradicional da palavra. Essa ontologia não pode de maneira alguma ser considerada uma filosofia primeira - como as ontologias substancialistas do passado (o título de Wolff diz tudo: Philosofia prima sive ontologia). Uma ontologia da relação deve, em vez disso, ser considerada uma "segunda" filosofia, uma filosofia que deve sempre ser pensada na contingência da connexio singularis das relações historicamente dadas. Longe de ser uma primeira filosofia, tal ontologia não será nada menos - ou mais - que um banimento metodológico ou um abandono metódico de tal pretensão". (Morfino, 2014, p.71)

É dessa perspectiva de uma filosofia segunda que aciono os conceitos espinosanos, a fim de pensar algumas formações sócio-políticas contemporâneas - movimentos e instituições - como resultantes da articulação de distintas ideiaspaixões. Do ponto de vista da causalidade imanente - ou sub specie aeternitatis -, em última instância, o fundamento desses corpos políticos, o que neles circula, o que os anima, o que os sustenta, é o desejo. Se paixão é prática, formações sóciopolíticas são, sobretudo, formações biopolíticas: um conjunto de dispositivos e discursos capazes disseminar e moldar práticas individuais para constituir um corpo político-social a partir de uma multidão.

\section{3 \\ Da multidão ao corpo político}

A metáfora do político como corpo não é nova. Como aponta Vladimir Safatle (2016), é possível encontrá-la nos principais nomes da filosofia política moderna, como Rousseau, Hobbes - além, é claro, de Espinosa. Rousseau, por exemplo, chega a descrever o contrato social como um ato de associação que produz "um corpo moral e coletivo composto de tantos membros quantos são os votos da assembleia" (Rousseau apud Safatle, 2016). O Leviatã, por sua vez, é um gigantesco corpo soberano sustentado pela multidão. Metáforas como essa, como pontua o autor, não são meramente ilustrativas: são formas de "relacionar sistemas 
de referências distintos que devem, porém, ser conjuntamente articulados para que um fenômeno determinado possa ser apreendido de modo adequado" (Safatle, 2016, p.19). Como já visto, a partir de Deleuze e Guattari, um corpo pode ser caracterizado por sua capacidade de afetar outros corpos e de ser igualmente afetado por eles. Nos termos de Safatle, um corpo caracteriza-se por sua capacidade "de entrar num regime sensível de aesthesis" (Safatle, 2016, p.19). Estética e política, portanto, aparecem intimamente relacionadas na composição de corpos políticos. É nesse sentido que o autor descreve esses corpos como circuitos de afetos.

A concepção dos corpos políticos como circuitos de afetos, na obra de Safatle, é semelhante, em muitos aspectos, à concepção dos corpos políticos na obra de John Protevi (2001; 2011a), onde aparece como body-politics e forceful body-politics, algo que se pode traduzir como corpos políticos constituídos de forças. A abordagem de Protevi, no entanto, parece partir dos corpos menores em direção aos corpos maiores: em vez de começar pela demonstração de como o espaço político constitui um corpo, o autor procura começa por mostrar como um corpo funciona, ele mesmo, como um espaço político - algo que corrobora a concepção espinosista, desenvolvida anteriormente, a partir de Morfino. Para Protevi, a dimensão afetiva desempenha um papel determinante na constituição de corpos capazes de afetar e serem afetados (Protevi, 2011b). Para esse autor, Deleuze e Guattari operacionalizaram o afeto para compreender a produção de agenciamentos. Um agenciamento é, para Deleuze e Guattari, uma multiplicidade, uma estrutura funcional que conserva a heterogeneidade de seus componentes. Um aspecto fundamental desse arranjo, enfatizado por Protevi, é que o afeto, conforme concebido por esses autores, é ao mesmo tempo fisiológico, psicológico e maquínico:

(...) ele imbrica o social e o somático na formação de um "corpo político" [body politic] que sente seu poder ou potência de agir aumentar ou decrescer conforme encontra outros corpos políticos e forma agenciamentos com eles (ou fracassa nessa tentativa). (Protevi , 2011b, p.394)

Como se pode perceber, não estamos muito distantes daquela definição de Safatle, a de corpos políticos como circuitos de afetos. Para Protevi, essa noção de agenciamento como uma estrutura funcional emergente, ou seja, um sistema composto por elementos heterogêneos e dispersos, dotado de agência na medida 
em consegue fazê-los funcionar como um corpo, encontra paralelo nas descobertas recentes da ciência cognitiva, mais precisamente, nas escolas da mente incorporada (embodied) estendida (extended), que postula que "a cognição opera em loops entre o cérebro, o corpo e o meio ambiente" (Protevi, 2011b, p.395). A ênfase nesses estudos, no entanto, recai sobre a cognição. Deleuze e Guattari, por sua vez, dão destaque à dimensão afetiva desses agenciamentos. A proposta de Protevi é abordar essas dimensões de afeto e cognição como parte de um único processo de cognição afetiva. Para ele, afeto e cognição atuam em conjunto na constituição dos corpos políticos. A semelhança com o conceito de “ideia-paixão" ou de "ideias passionais", que Morfino extrai de Espinosa, deve estar evidente a esta altura. Assim como a cognição afetiva que, para Protevi, surge no contato do corpo com o exterior, ou o meio ambiente, o mesmo ocorre com as ideias-paixões. $\mathrm{Na}$ interpretação de Morfino, "ideias-paixões" ou "ideias passionais" não são "estados interiores", porque mente e corpo, já sabemos, operam em uníssono no espinosismo. "Paixões (...) são o corpo e suas ações" (Morfino, 2014, p.67).

O conceito de multidão, em Espinosa, é importante para compreendermos a definição dos corpos políticos por Protevi, que parte de corpos políticos menores (os corpos humanos) e se encontra, no meio do caminho, com aquela de Safatle, que parte dos corpos políticos coletivos. Para Espinosa, a multidão se caracteriza por uma paixão que é prática. Nela vontade e intelecto - afeto e cognição - são uma só coisa: só existem como eventos singulares ${ }^{54}$. Morfino (2014) aponta que essa concepção está presente, por exemplo, na compreensão espinosana do papel do ritual no estado hebraico, algo discutido no Tratado Teológico-Político. Nele, as ideias-paixões atravessam o corpo social para, ao mesmo tempo, disseminar e moldar práticas individuais, convertendo o indivíduo num ser social e, assim, permitindo a construção de um corpo político-social a partir uma multidão. Essa abordagem é particularmente interessante para os objetivos propostos nesta dissertação.

Essa mesma concepção dos corpos políticos como corpos desejantes está presente no conceito de estruturalismo das paixões, em Frédéric Lordon, que postula que "A sociedade é movida por desejos e afetos" (Lordon, 2015, p.7).

\footnotetext{
${ }^{54}$ Nesse sentido, para Morfino, o que emerge da Ética espinosana é precisamente o relacionismo radical, buscado por Paci.
} 
Lordon acredita que para compreender a sociedade é preciso compreender os afetos (o que são? como surgem? o que significam?). Por questões metodológicas, ele argumenta, é essencial que essa investigação dos afetos não se dê numa perspectiva subjetivista, que poderia redundar em mero psicologismo; para tanto, é preciso "ficar com os afetos, mas se livrar do sujeito" (Lordon, 2015, p.10). É justamente isso que Espinosa, como vimos antes, nos permite fazer. A imagem de indivíduo, que emerge do espinosismo, é a de uma singularidade constituída nas relações que desencadeiam afetos que acontecem não nos indivíduos, mas entre indivíduos (é, portanto, transindividual). Indivíduos que, por sua vez, não preexistem às relações passionais, mas são, nelas, individuados: indivíduos, portanto, são sociais - ou socializados $-a$ priori $^{55}$. Não há espaço no sistema de Espinosa para um indivíduo monádico, absolutamente livre e soberano, na medida em que todos os indivíduos participam de uma única totalidade relacional, a ideia de um individuo isolado é um contrassenso. Para Lordon, o paralelismo espinosano abre caminho para uma abordagem materialista dos afetos, uma formulação que já víramos em Althusser. Lordon (2015) dá a isso o nome de estruturalismo das paixões. Para Espinosa: "Existem, sim, indivíduos e eles experimentam afetos, mas esses afetos não são senão efeitos das estruturas nas quais os indivíduos estão mergulhados" (Lordon, 2015, p.10). Pode-se dizer que no estruturalismo das paixões, proposto por Lordon, as estruturas equivalem à substância espinosista e os indivíduos, aos modos. Os indivíduos singulares são, para Lordon, expressões locais de estruturas globais.

Existem estruturas, e nas estruturas existem homens passionais, em primeira instância, os homens são movidos por suas paixões; em última análise, suas paixões são amplamente determinadas pelas estruturas; eles são movidos frequentemente em uma direção que reproduz estruturas, mas, às vezes, em outras, que as desfaz para criar novas. (Lordon, 2015, p.10)

Estruturas incidem sobre corpos, suscitando ideias-paixões que atravessam o corpo social para, ao mesmo tempo, disseminar e moldar as práticas individuais que darão origem (ou não) aos diversos corpos políticos que povoam o espaço social: organizações, corporações, empresas, movimentos, partidos e instituições de toda ordem que se tornam, elas mesmas, fontes (poderosas) de afetos... afetos

\footnotetext{
${ }^{55}$ Algo que, como será visto mais à frente, está presente na apresentação do conceito de habitus, em Pierre Bourdieu. É por Bourdieu, a propósito, que Lordon procura promover a aproximação do espinosismo à sociologia contemporânea.
} 
que geram mais ideias-paixões, num movimento que vai incessantemente do local ao global; esse efeito de causalidade imanente remete aos feedback loops da cibernética. Mas os corpos políticos, no entanto, não constituem sistemas fechados. São sistemas abertos. E os afetos homogêneos que ele produzem repercutem de modo heterogêneo nos diferentes ingenia que entram na relação institucional.

O conceito de ingenium - que se pode traduzir como "engenho" ou "gênio" - é às vezes traduzido como temperamento, mas talvez seja mais preciso traduzilo como compleição, uma vez que essa palavra pode ser utilizada para se referir tanto à constituição física quando psicológica ou moral de indivíduos ou grupos. Lordon (2013) usa a palavra complexão (complexion) e para se referir ao ingenium usa complexão afetiva. Uma das características do ingenium, nesse sentido, é ser uma espécie de memória afetiva, o resultado de uma trajetória social e biográfica que nos marca física e psicologicamente (Lordon, 2013, p.97). O ingenium é um hábito do pensamento - e também do corpo -, a síntese de um modo de vida, de uma história particular, aquilo que nos permite reconhecer distintamente um indivíduo ou um povo dos outros (Jaquet, 2011).

De acordo com Lordon, “as estruturas se exprimem nos indivíduos como desejos" (Lordon, 2015, p.13), mas os desejos variam segundo cada ingenium; os desejos são resultado do encontro de um interior socialmente constituído com um exterior que é ele mesmo constituído de pontos de convergência afetiva; os movimentos desejantes individuais reproduzem, mantém, nutrem os corpos político-sociais (formam, como diria Safatle, circuitos de afetos); ou os dissolvem, quando o desejo muda de direção, para se exprimir numa outra estrutura. Nessa abordagem estrutural das paixões, os indivíduos se manifestam como potências desejantes, que podem ora convergir numa instituição, ora noutra, sempre sob condições determinadas.

Existem forças motrizes no seio das estruturas, forças frequentemente determinadas pela reprodução do mesmo, mas eventualmente capazes de se mover em direções inéditas, que vêm quebrar o curso ordinário das coisas, ainda que sem escapar da ordem causal da determinação - quando, por exemplo, o funcionamento das estruturas se torna um tanto insuportável aos olhos dos indivíduos e os encaminha, desse modo, não mais à conformidade, mas à sedição. (Lordon, 2015, p.11) 
Lordon argumenta que - como já apontavam Mauss e Durkheim instituições são realidades exteriores ao indivíduo que aparecem no princípio de determinadas afecções. São, portanto, capazes de pôr corpos em movimento e nisso, precisamente, reside sua eficácia.

Se as instituições recebem algo dos indivíduos, se elas o induzem com sucesso a certos comportamentos (é isso e apenas isso que se deve entender por "eficácia"), a parar no sinal vermelho, por exemplo, a aceitar a moeda em circulação ou a respeitar o regulamento interno da fábrica é porque elas têm o poder de afetá-los. Este é o silogismo espinosista da ação: pelo encontro com certas coisas exteriores, os indivíduos sentem certas afecções que os afetam de certa maneira e os impelem a desejar fazer certas coisas. Os afetos são o modus operandi da eficácia institucional. (Lordon, 2015, p.14)

Pierre Bourdieu, com quem Lordon dialoga em sua obra, dá a esses ambientes institucionais que constituem o modus operandi das instituições o nome de "campo". O campo, argumenta Lordon, é “o lugar por excelência de uma oferta aos conatus, convidados a se investir nas apostas particulares instituídas pelo campo" (Lordon, 2015, p.75). Para o autor, as instituições resultam, portanto, de uma aposta dos conatus. Ninguém entra numa relação institucional assim como não faz uma aposta - para perder. Até porque o desejo, no espinosismo, não pode ser compreendido no sentido vulgar, como euforia ou obsessão desencadeada por este ou aquele objeto: o desejo às vezes é mero desejo de evitar um mal. Entra-se numa relação de trabalho, por exemplo, em nome de um salário que nos dê acesso a meios de subsistência. Suportam-se determinadas instituições policiais ou jurídicas em nome de uma promessa de segurança. Respeitam-se determinadas regras e ritos acadêmicos em nome de um diploma (ou do capital simbólico que ele pode conferir). Na sociologia de Bourdieu, cada um desses exemplos (o trabalho, a justiça, a academia) constituem campos e "cada campo propõe objetos específicos para capturar os desejos flutuantes - e para fixar aqueles já captados" (Lordon, 2015, p.75).

Bourdieu chama de illusio essas formas assumidas pela energia conativa e de estruturas de campo os investimentos que a determinam localmente. Os campos, argumenta Lordon, "são realizações concretas do estruturalismo das paixões, isto é, lugares de desejos, afetos e imaginário estruturalmente organizados" (Lordon, 2015, p.75). As instituições exercem, portanto, um "poder positivo de informação" (Lordon, 2015, p.75). Lordon de refere a esse poder 
como um poder hilemórfico, num sentido tomado de empréstimo de Aristóteles: as instituições dão forma ao conatus amorfo, compreendido como potência genérica. A exterioridade do social, cristalizada nas instituições, não é de ordem puramente repressiva, mas é também o lugar onde o conatus intransitivo se atualiza em desejo disto ou daquilo.

[As] estruturas globais se exprimem localmente por meio dos afetos que as produzem. Justamente porque esses afetos são produzidos nos corpos individuados é que eles devem ser considerados locais. Ainda que possam ser efeitos de estruturas sociais, globais por natureza, há uma localidade intrínseca dos afetos: não existe afeto sem corpo a afetar. (Lordon, 2015, p.76)

Para Lordon, a dimensão psíquica é locus de inscrição (local) do social (global), do mesmo modo que a psique é, para Morfino, a flutuação de ânimo constituída pelo atravessamento das paixões que nos constitui como res singulares ou, dito de outro modo, como complexos psicossomáticos. Os afetos globais são processados localmente de acordo com o ingenium - ou complexão afetiva - de cada um. Os afetos que experimentamos, portanto, resultam aí do encontro de um ingenium, de uma circunstância e de uma afecção.

Lordon argumenta, a partir de Espinosa, que uma instituição deixa de ser eficaz quando perde sua capacidade de colocar os corpos em movimento. Quando deixa de produzir nos corpos que lhes dão sustentação os afetos que os movem ou quando deixa de se apresentar como oferta ao conatus. Na grande maioria das vezes, diz, isso ocorre quando a instituição produz um excesso de afetos tristes medo, insegurança, opressão etc. Isso instaura, por assim dizer, uma crise na economia afetiva que, eventualmente, se torna insustentável e inclina o indivíduo a um desejo de fuga. Os limites de tolerância das pessoas variam, evidentemente, de acordo com o ingenium de cada uma. "Existem, no entanto, afecções que submetem muita gente aos seus limites, e transformam, então, uma divergência individual em movimento coletivo" (Lordon, 2015, p.80).

Em seu Tratado Político, Espinosa dá a esse sentimento o nome de indignação e traduz por meio dele um descontentamento político que indica "o limite do poder de afetar de uma instituição" (Lordon, 2015, p.81). A indignação se manifesta, portanto, como um sentimento antiestablishment, como sintoma de um movimento centrífugo dos afetos, uma fuga de investimentos afetivos. Em termos políticos, a indignação, para Lordon (2015), é a antessala da sublevação, 
da revolta, da sedição. Um indicativo de que embora as instituições possam levar os indivíduos a fazerem muita coisa, não os podem levar a fazer qualquer coisa (pelo menos, não o tempo todo).

qualquer instituição não passa de uma estabilização temporária de certa relação de potências, sendo esta a mesma que tal instituição estabelece com os indivíduos contidos (a conter) em seu império. O imperium da instituição nada mais é do que o afeto comum que ela consegue produzir para determinar que os indivíduos vivam de acordo com sua norma. (Lordon, 2015, p.81)

Ao reconhecimento dessa autoridade institucional por parte dos indivíduos envolvidos nessa relação, Espinosa dá o nome de obsequium. É em nome do obsequium que demonstramos respeito às instituições e, com (mais ou menos) bondade de ânimo, lhes prestamos favores. O obsequium é um afeto que surge de nossa relação com as intuições, um afeto do qual elas dependem, mas que só existe enquanto não é suprimido por um afeto contrário e mais forte ${ }^{56}$.

Tal qual o Estado analisado por Espinosa no Tratado Político, “(...) o imperium institucional é incapaz de estabilização definitiva" (Lordon, 2015, p.81). Nas palavras de Lordon: "Não existe instituição para sempre, porque as instituições devem existir com os indivíduos que as habitam - ainda que se pense o contrário" (Lordon, 2015, p.82). É na passagem do obsequium à indignação que se engendram as sedições desde que, é claro, esse afeto seja "compartilhado em escala suficientemente grande para, como afeto comum reacional, colocar-se contra o afeto comum institucional" (Lordon, 2015, p.82). Apoiando-se no pressuposto de que "nada pode congelar a dinâmica dos afetos" (Lordon, 2015, p.82), o autor considera possível religar o estruturalismo das paixões à transformação e à história justamente nesse ponto em que o fracasso da relação institucional permite que nela se opere uma transição do afeto comum predominante do obsequium para a indignação.

Pelo curto-circuito de uma metonímia que confunde o processo gerador com o efeito engendrado, poderíamos, portanto, dizer que uma relação social, uma estrutura, uma instituição nada mais são do que afetos comuns. Mas o que um afeto

\footnotetext{
56 "Indo da reprodução do regime à crise aberta, a relação de potência entre o obsequium institucional e os afetos contrários, reacionais, que fazem nascer muito frequentemente a subordinação e o comando, essa relação entre a instituição e seus sujeitos é, em graus diversos, sempre tensa." (Lordon, 2015, p.81)
} 
comum sustenta, outro afeto comum, contrário e mais potente, pode desfazer. (Lordon, 2015, p.83)

Aí reside o caráter dinâmico do estruturalismo das paixões. Há uma balança afetiva que determina a aderência ou não dos "polos de potência individuados" (Lordon, 2015, p.83) às instituições. É difícil precisar, no entanto, quando o acúmulo de afetos tristes processados pelos diferentes ingenia vai produzir um afeto comum de indignação, difícil prever qual a fagulha que pode incendiar a pradaria, pra usar a famosa frase de Mao Tsé-Tung. Mas é certo que, quanto mais seca a palha estiver, maior o risco de combustão.

Esse é um dos aspectos do estruturalismo das paixões que mais interessa se quisermos pensar o populismo como forma de constituir corpos políticos: "as estruturas não se mexem por si mesmas, 'alguém’ mexe nelas” (Lordon, 2015, p.15). Esse alguém é a política. Na lógica do estruturalismo das paixões: as coalizões de forças desejantes. Na lógica laclauniana, é o corte populista.

\section{4 \\ A razão populista e a coalizão de forças desejantes}

Se tantas linhas foram dedicadas à apresentação e à discussão do conceito laclauniano de populismo foi para chegar neste ponto. $\mathrm{O}$ que interessa aqui é compreender de que modo o populismo pode operar como um catalizador de afetos de indignação. Vimos, nos capítulos anteriores, que o soft power neoliberal opera, em grande medida, fazendo ofertas ao conatus, como diria Lordon. Promessas de autonomia, liberdade, realização. O que parece indicar a mudança recente na armadura institucional do capitalismo, que se procurou, em linhas gerais, ilustrar nos capítulos anteriores, é que esse já não é mais o modus operandi predominante do neoliberalismo no recrutamento das potências desejantes (pessoas) que lhe dão sustentação. É isso que parecem indicar, pelo menos, as análises de Piketty sobre o crescimento da desigualdade, que discutimos brevemente no primeiro capítulo. Mas é isso que aponta também Christopher Dejours (2016), quando enfatiza o papel do que podemos chamar aqui de afetos tristes como recurso motivacional de trabalhadores. Um desses afetos, talvez a forma mais básica de "motivar" alguém a perseverar num emprego - a despeito da insalubridade, da exploração, da pressão constante por resultados, do esgotamento 
físico e psicológico, do assédio moral - é o medo do desemprego. É o modo de ser lançado, de repente, para o outro lado. O lado dos que penam para ter acesso aos itens mais básicos para a sobrevivência. Esse dispositivo hoje em dia se manifesta de modo cada vez mais evidente, por exemplo, em certas reformas trabalhistas. Vendidas ao público geral como "modernização", como forma de tornar a indústria nacional mais competitiva num cenário de economia globalizada $\mathrm{e}-\mathrm{o}$ argumento mais importante - como forma de gerar mais empregos, o maior apelo dessas reformas é direcionado ao esforço das pessoas para perseverar no ser que, em muitos casos, significa simplesmente sobreviver, se alimentar, se vestir, criar os filhos. Como não cansa de insistir Frédéric Lordon, é esse afeto triste, essa insegurança, essa ameaça de impotência que está na base da relação assalariada.

O primeiro aguilhão do movimento assalariado, conceitual e historicamente, é o temor de morrer e o desejo de não morrer - no qual percebemos ocasionalmente, que o desejo não é necessariamente o impulso positivo e alegre que representamos com espontaneidade. E, na verdade, na primeira relação histórica da relação salarial - que não vai além de suas formas elementares -, a movimentação dos corpos assalariados se efetua em uma atmosfera de afetos tristes: o medo da miséria. Medo do depauperamento, desejo vital de acessar o dinheiro, transformado nas estruturas sociais do capitalismo em ponto de passagem obrigatória da perseverança no ser: isso é exatamente um regime de desejos e de afetos. (Lordon, 2015, p.192, grifo meu)

Pra quem está empregado, as mudanças estruturais do capitalismo têm reflexos diretos no clima organizacional. Impactam, sobretudo, no imaginário da realização profissional, tão presente na teoria e na retórica da administração investigadas por Boltanski e Chiapello (2005) em O novo espírito do capitalismo, precisamente, o conjunto de técnicas de gerenciamento ou gestão de recursos humanos que emergiram na virada para os anos 1970.

O título do livro de Boltanski e Chiapello (2005), obviamente, faz alusão ao clássico de Max Weber, a partir do qual os autores argumentam que ao longo da história teriam existido pelo menos três "espíritos". O primeiro deles teria se manifestado no empreendedor burguês, filho do século XIX, caracterizado pelo seu ímpeto prometeico, pela sua tolerância ao risco e pela sua vontade de inovação, virtudes que ascendiam no imaginário moderno em paralelo à ética protestante, marcada pela frugalidade, pela austeridade, pelo vínculo familiar. No entreguerras, entre 1930 e 1960, teria se configurado um novo espírito, dessa vez, 
nos visionários diretores das grandes indústrias, que sonhavam mudar o mundo com seus planos de longo prazo, sua gestão centralizada e sua organização racional do trabalho. Na indústria, nessa época, a trajetória até o topo se constituía como uma estrutura fixa e estava, em tese, bem claro para todos o que era necessário fazer pra chegar até lá (tudo isso traduz, evidentemente, a lógica do fordismo). Na virada para a década de 1970, mais precisamente após o Maio de 1968, na França (os autores se concentram no cenário francês), esse espírito começou a ser exorcizado, tendo sido submetido a uma avalanche de críticas, que o caracterizavam como uma ficção autoritária e arcaica, pouco adequada à realidade. As promessas de uma carreira que exigia dedicação, abnegação, paciência e muito sacrifício já não atraiam a juventude contestadora gestada no caldeirão de efervescência política que foi a década de 1960. Para compreender o que se passou nessa virada de década, e a ascensão do terceiro novo espírito do capitalismo, Boltanski e Chiapello (2005) consultaram os textos de administração, para ver o que eles tinham a dizer. Os autores observaram que essa literatura apontava, então, uma grande preocupação com a insatisfação em relação à gerência e sugeria, como saída para esse problema, a adoção de modelos mais descentralizados, meritocráticos e a concessão de uma autonomia limitada aos gerentes. Outro temor, identificado entre os autores desses textos de administação, era com a presença de vínculos patriarcais ou familiais entre os empregados, como favoritismo, nepotismo, falta de distinção entre o pessoal e o profissional, comportamentos que poderiam comprometer a racionalidade ou a objetividade do gerenciamento. Nos anos 1990, apontam os autores, tudo que poderia ser associado a hierarquia ou verticalização passou a ser fortemente rejeitado em textos de administração (era economicamente dispendioso, moralmente inaceitável). A mudança permanente, a adaptabilidade, a capacidade de responder às ameaças crescentes da competição no mercado global - ou da "globalização", que nesses textos virou a palavra da vez. O modelo da rede emergia então - na esteira das novas tecnologias de comunicação, notoriamente, da Internet - como um novo paradigma para a administração. Tal mudança vinha acompanhada de uma série de mudanças retóricas importantes: os gerentes tornavam-se, de repente, líderes ou coordenadores; os trabalhadores tornavam-se, de uma hora para outra, colaboradores: cabia aos líderes inspirá-los, motivá-los e engajá-los. A empresa era retratada, por sua vez, como um grande time que tinha no conhecimento seu 
bem mais precioso - vivíamos, afinal, na "sociedade da informação" - já que agora uma série de atribuições (e custos) podiam ser "externalizados" por meio da terceirização. Virtudes como carisma, comunicação, intuição visão, generalismo e flexibilidade passaram a ser utilizadas para caracterizar as lideranças do novo milênio. O controle passou a ser algo internalizado por cada empregado, no qual os líderes depositavam sua confiança - e seu "sonho". O foco no cliente fornavase um parâmetro para orientar as ações desses colaboradores e as pressões da competição incidiam agora com muita força sobre eles.

O novo espírito do capitalismo levou ao extremo a arte de governar - de dar direção, de estimular e, ao mesmo tempo, manter dentro de certos limites - as essências desejantes. Como argumenta Lordon (2015), fazer prevalecer uma norma - ou, por que não dizer, sustentar uma hegemonia - "é uma questão de produção de afetos e desejos. Etimologicamente, é uma questão de epitumogenia (do grego epithumia, desejo)" (Lordon, 2015, p.191). Nesse ponto, Foucault e Espinosa andam lado a lado:

Se a governabilidade é arte de conduzir as condutas, então, ela é fundamentalmente da ordem da epitumogenia, já que é afetando os indivíduos que os determinamos a se conduzir de determinada maneira. Ela é, desse modo, uma ars affectandi por natureza: governar é afetar. (Lordon, 2015, p.191)

O bom governante, gerente ou líder é, dessa perspectiva, o mais eficaz. E o mais eficaz é aquele capaz de guiar as condutas, estimulando, prioritariamente, os afetos felizes; afetos que, ao menos imediatamente, produzem um aumento na potência de agir. O amor, "alegria acompanhada da ideia de uma causa exterior" (E3Daf6, p.241), pode ser a empresa, mas também o gerente; pode ser o país, mas também o presidente. A esperança, "alegria instável, surgida da ideia de uma coisa futura ou passada, de cuja realização temos alguma dúvida" (E3Daf44, p.255), pode ser uma promoção futura, mas também o fim de uma crise econômica; pode ser a eleição de um novo presidente (ou reeleição de um antigo), mas também a volta dos militares. A ambição, o "desejo imoderado de glória" (E3Daf44, p.255) que "intensifica e reforça todos os afetos (...) e dificilmente pode ser superado" (E3Daf44, p.255), pode ser materializado no desejo de cargo elevado, uma vida de ostentação, uma montanha de dinheiro; mas pode também se expressar como desejo de uma "lacração", um "turn down for what" nas redes sociais. A emulação, "o desejo de uma coisa que se produz em nós por 
imaginarmos que os outros têm o mesmo desejo" (E3Daf33, p.253), que se traduz nas modinhas, no desejo de imitar, de fazer o que os outros fazem e todo mundo diz que é legal, é bom, é massa. A gratidão, o desejo de "fazer bem a quem, com igual afeto de amor, nos fez bem” (E3Daf44, p.255), expressa na fidelidade ao gerente que tolerou um deslize, ao partido ou político que implantou uma política social, a um movimento social ou uma igreja que o acolheu num momento difícil. A glória, "uma alegria acompanhada de alguma ação nossa que imaginamos ser elogiada pelos outros" (E3Daf30, p.251): a lisonja que sentimos ante o olhar de inveja do outro, os aplausos que recebemos. A adoração, o amor que sentimos por "aquele a quem admiramos" (E3Daf10, 243); o líder inspirador, o gênio da inovação.

A epitumogenia neoliberal nunca deixou de recorrer a todos esses expedientes para se consolidar, em todas as esferas. $\mathrm{O}$ que vale para o ambiente das empresas transborda, como vimos anteriormente, para todos os campos e se traduz no ideal do empresário de si. O que importa notar é que, nesse cenário, os afetos tristes - o medo, a insegurança etc. - nunca deixaram de exercer certo protagonismo. O medo do desemprego, nesse ambiente "flexível" (instável) e exigente, tornou-se cada vez mais onipresente. Era agora o medo de não atender às expectativas do grande líder (e perder o emprego), e medo de ser superado pela competição (e perder o emprego), de não ser suficientemente capacitado (e perder o emprego). Para os mais bem-sucedidos, o medo do desemprego possivelmente não pesava tanto, mas pesava igualmente o medo de perder o status - ou pesava o peso da coroa (quantas vezes não vimos, nas duas décadas passadas, capas de revistas de negócios falando sobre a vida dura dos CEOs e, por vezes, suas batalhas contra a depressão?).

Vimos já neste trabalho que uma das caracteristicas que Wendy Brown (2015b) identifica nas técnicas de governança que ascenderam, digamos, no neoliberalismo tardio, foi combinar o máximo de autoridade com o máximo de responsabilização, configurando um poder que é exercido, ao mesmo tempo, de forma massiva e singular. Frédéric Lordon (2014), por sua vez, aponta como a cadeia de comando funciona, dentro desse novo espírito do capitalismo, de modo a fazer com que a pressão exercida sobre as lideranças pela competição incida com força redobrada sobre a média gerência (o gerente que tem seu posto ameaçado, sua competência questionada), mas incidam, sobretudo, com muito 
mais força sobre os "colaboradores", aqueles que se encontram sempre mais perto da porta da rua. A competição, que acontece no ambiente externo, se reproduz também internamente. Os colaboradores precisam mostrar serviço, especialmente quando a empresa se encontra ameaçada pelos competidores, para garantir que, em caso corte de custos, a cabeça a rolar não seja a deles.

Não é difícil compreender por que, num cenário como esse, um dispositivo como a greve tem cada vez menos apelo para os "colaboradores" e os sindicatos, que já tinham saído enfraquecidos do embate com os governos neoliberais, no processo de mudança da armadura institucional do capitalismo, e agora parecem perder de vez praticamente todo seu poder de pressão. Exceto, claro, naqueles lugares onde a segurança no emprego é mais ou menos assegurada pela lei, como no caso das empresas públicas, ou em indústrias em que, por sua área de atuação, o regime fordista ainda parece ter algum valor - pelo menos enquanto a automação não elimina por completo a necessidade de trabalhadores braçais como a metalurgia, a indústria automobilística, a mineração e a extração de petróleo, entre outras. Mesmo nesses casos, no entanto, o novo espírito dá as caras, como se pode depreender tanto da análise de Dejours (2016) quanto da de Lordon (2014). Acontece que as promessas de realização pessoal, para o chão de fábrica, estão longe de representar a mesma oferta ao conatus que representam para os "colaboradores" cujo papel é ser a "cabeça pensante" desses processos, aqueles que hoje se encontram mais próximos daquilo que Yann Moulier Boutang (2008) chamou de capitalismo cognitivo, no qual o trabalho imaterial, associado à produção de conhecimento, às novas tecnologias de comunicação, à análise de dados e à inovação, entre outras coisas, ocuparia o centro da produção de valor. A divisão entre white collars, os trabalhadores do escritório, da sede, e os blue collars, os chão de fábrica, os peões, reproduz ainda a distância entre o trabalho intelectual e o trabalho material, entre concepção execução. Algo que, dada a complexidade que atingiu o processo da divisão do trabalho hoje, só seria contornável por meio da automação (Lordon, 2014).

Automação que, por sua vez, impõe questões de outra ordem, que impactam diretamente no crescimento da desigualdade, na inversão da Curva de Kuznets, no aumento do abismo entre o $1 \%$ mais rico e o resto. Além de muita qualificação, o domínio técnico de um imenso conjunto de habilidades, o capitalismo cognitivo não parece ter, hoje, condições de absorver a mão de obra que, num cenário de 
avanço exponencial da automação, ficaria desempregada. Hoje, o avanço da Inteligência Artificial ameaça, até mesmo, o emprego dos trabalhadores imateriais. Não faltam notícias, nos últimos anos, alertando para os empregos, nessa área, que estão com os dias contados, pois em breve poderão ser substituídos com sucesso por robôs. O que parece óbvio, quando se contempla esse cenário, é que não vai ter lugar pra todo mundo. Que o desemprego vai se tornar um problema crônico. E que se, por um lado, as economias centrais caminham a passos largos em direção à automação, nos países periféricos nada garante que esse é um caminho que poderá ser trilhado com a mesma rapidez. $\mathrm{O}$ que as reformas trabalhistas que aconteceram este ano no Brasil parecem indicar, por exemplo, é que, por aqui, optou-se por outro caminho: o de garantir a competitividade da economia no cenário internacional por meio da precarização. É exploração de mais valor-absoluto, para falar na língua de Marx (2013): intensificação do ritmo e da carga horária de trabalho, por meio de um controle cada vez mais intenso da produção, mecanismos de vigilância, cronometragem do tempo e controle dos movimentos. Não se sabe ao certo ainda nem qual vai ser a eficácia dessa estratégia como tentativa de dar mais competitividade à indústria nacional, nem quais os limites - físicos, psicológicos e até morais - dessa exploração. Não se sabe, nem mesmo, até quando esse paliativo poderá servir para adiar um cenário que parece cada vez mais plausível: o de desemprego estrutural.

Para Zizek (2012), é esse o cenário que se desenha no horizonte capitalista. O filósofo esloveno acredita que o desemprego estrutural não compreende apenas o desempregado clássico, aquele para o qual o desemprego tem caráter temporário. Juntam-se a ele também a imensa massa de trabalhadores precários, terceirizados, free-lancers, "pejotas" - como ficaram conhecidos aqueles que foram obrigados a constituir uma Pessoa Jurídica para vender seus serviços no mercado - todo conjunto de trabalhadores temporários, enfim, que muitos estudiosos têm pensado a partir dessa categoria do precariado, que engloba aqueles trabalhadores carentes de direitos trabalhistas e de representação, para os quais temporário não é o desemprego, mas o emprego. Além dos temporariamente desempregados e dos temporariamente empregados, o desemprego estrutural inclui, para Zizek, os permanentemente desempregados, os “inimpregáveis" que se concentram nas periferias, nos guetos, nas ruas, mas também existem em número cada vez maior na classe média, onde aparecem 
como a juventude educada e "inimpregável", que sai das faculdades, mas não encontra lugar no mercado de trabalho. O que tudo indica é que essa tendência, se confirmada, deve aumentar cada vez mais o fosso entre possuidores e despossuídos, o que tem levado alguns autores a falar sobre um possível retorno, e de uma nova importância política, do populacho (Pöbel), investigado por Hegel na Filosofia do Direito (Ruda, 2011; Zizek, 2012), o grupo daqueles ficam para trás, nesses processos de modernização do capitalismo, cujas ambições, muitas vezes altíssimas, são insufladas pelas ofertas que o discurso neoliberal faz ao conatus, mas não dá meios de satisfazer; são pessoas que ficam de fora da sociedade organizada, excluídas do processo de produção, em uma condição de marginalidade e se constituem apenas como "negatividade abstrata", uma negatividade que se manifesta apenas por meio da violência e das explosões irracionais (Zizek, 2012).

Se aceitamos a hipótese do retorno do populacho, não fica difícil identificálo como um componente essencial da recente explosão populista nos Estados Unidos, com Trump, e na Europa, principalmente com o Brexit, mas também com a ascensão de partidos de extrema direita em diversos países. O que se observa, nesses exemplos, é a presença de uma série de significantes vazios e flutuantes que, em sua forma, não diferem muitas vezes daqueles mobilizados pelos movimentos, partidos e candidatos da esquerda que disputam esse público, com recurso à retórica populista $(\mathrm{O}$ Movimento 5 Estrelas, na Itália, o Podemos, na Espanha, e o Syriza, na Grécia, são bons exemplos). Durante as prévias da eleição norte-americana, não foram poucos os analistas que apontaram as semelhanças entre o discurso antiestablishment do republicano Donald Trump e o do democrata (e socialista) Bernie Sanders. Em questões econômicas, sobretudo, os candidatos se aproximaram em muitos pontos; por exemplo, na crítica ao Tratado Transpacífico, na questão do emprego, na crítica à política engessada de Washington. No caso do Brexit, ocorreu um fenômeno parecido. Muitas das críticas à política econômica imposta pelo Banco Central Europeu, que incendiaram o discurso da extrema-direita inglesa, vinham sendo feitas, há bastante tempo, por movimentos, partidos e políticos da esquerda mais radical da Inglaterra. É preciso pensar em que medida os discursos xenófobos, racistas, nacionalistas, e por vezes, a simples violência ou obscenidade dos discursos de uma figura como Donald Trump, podem ter contribuído para, nos termos de 
Laclau, fazer com que os significantes vazios e flutuantes mobilizados pela direita tenham se revelado mais fortes, pelo menos na atual conjuntura, mais capazes de produzir catexia.

Podemos buscar em Espinosa uma possível explicação, investigando um pouco mais de perto conceito de ingenium, aquele hábito do pensamento, e também do corpo, que é síntese de um modo de vida, de uma história particular, aquilo que nos permite reconhecer distintamente um indivíduo ou um povo dos outros. É o ingenium que, na filosofia de Espinosa, pode nos ajudar a entender as diferentes expressões da indignação presentes na recente explosão populista.

\section{5}

\section{A gênese de um ingenium}

De que é feito um ingenium? De que modo hábitos do pensamento e do corpo constituem uma singularidade, se não por meio de experiências que se dão no tempo e no espaço e, pouco a pouco, constituem coordenadas, pontos de referência que utilizamos para nos orientar nas experiências futuras? Esses elementos, que acumulamos ao longo das experiências, engendram no pensamento e no corpo uma determinada complexão afetiva. É no ingenium, nesse sentido, que parece encontrar-se a chave para uma leitura mais sofisticada do papel das afecções e de sua diferença em relação aos afetos. O ingenium possibilita explorar por que o encontro com um mesmo corpo/evento provoca afetos distintos num mesmo individuo em diferentes momentos, ou por que dois indivíduos têm afetos distintos a partir do encontro com um mesmo corpo/evento. E ajuda a explorar, também, por que determinadas afecções parecem mais propícias a disparar determinados afetos. E, ainda, por que certos clichês, certos lugares comuns, certas estruturas narrativas são mais propícias do que outras para alterar a relação de movimento e repouso entre as partes que constituem nossos corpos e, por meio disso, são mais capazes de nos pôr em movimento nesta ou naquela direção.

Na Definição Geral dos Afetos, Espinosa afirma o seguinte:

O afeto, que se diz pathema (paixão) do ânimo, é uma ideia confusa, pela qual a mente afirma a força de existir, maior ou menor que antes, de seu corpo ou de uma parte dele, ideia pela qual, se presente, a própria mente é determinada a pensar uma coisa em vez de outra. (E3DGA, p.257, grifos meus) 
Procurando esmiuçar a "gramática da potência", Lordon (2015) afirma, por sua vez, o seguinte: "como potência é o poder de afetar, isto é, o poder de uma coisa produzir efeitos sobre outra ou várias outras, o afeto é o efeito em determinada coisa da exposição à potencia de agir de uma ou várias coisas" (Lordon, 2015, p.69). Lordon aponta que muitas vezes essa concepção é recusada, como mero fruto de uma concepção mecanicista, por aparentemente não dar conta da questão do sentido, das significações que, sem dúvida, desempenham um papel preponderante na maneira como os seres humanos organizam suas vidas. O que escapa a essa crítica é que a questão do sentido não está ausente na teoria dos afetos. Nela, o sentido é "um efeito da ordem geral da potência" (Lordon, 2015, p.69), o que está explícito na definição dos afetos: "Por afeto compreendo as afecções do corpo, pelas quais sua potência de agir é aumentada ou diminuída, estimulada ou refreada, e, ao mesmo tempo, as ideias dessas afecções (E3D3, p.163).

A produção de sentido, mais precisamente, deve à potência do corpo a ligação de suas afecções e à potência da mente a ligação de suas ideias. A associação, tal qual ela possa se fixar numa memória, é, assim, um dos efeitos mais característicos da potência do corpo-mente humano. "Se o corpo humano foi, uma vez, afetado, simultaneamente, por dois ou mais corpos, sempre que, mais tarde, a mente imaginar um desses corpos, imediatamente recordará também dos outros" (E2P18). A associação está também no início da doação de sentido, e primeiramente por sua inserção numa língua. "Compreendemos assim, claramente, por que a mente passa imediatamente do pensamento de uma coisa para o pensamento de outra que não tem com a primeira qualquer semelhança. Por exemplo, um romano passará imediatamente da palavra pomum [maçã] para o pensamento de uma fruta, a qual não tem qualquer semelhança com o som assim articulado, nem qualquer coisa em comum com ele, a não ser que o corpo desse homem tenha sido, muita vezes, afetado por essas duas coisas, isto é, que esse homem tenha ouvido, muitas vezes, a palavra pomum, ao mesmo tempo que via essa fruta" (E2P18Esc). Porém, essas ligações relacionando as coisas encontradas umas às outras, podem chegar a organizá-las em conjuntos significantes: "E, assim, cada um passará de um pensamento a outro, dependendo de como o hábito tiver ordenado, em seu corpo, as imagens das coisas. Com efeito, um soldado, por exemplo, ao ver os rastros de um cavalo sobre a areia, passará imediatamente do pensamento do cavalo para o pensamento do cavaleiro e, depois, para o pensamento da guerra, etc. Já um agricultor passará do pensamento do cavalo para o pensamento do arado, do campo, etc. E, assim, cada um, dependendo de como se habituou a unir e concatenar as imagens das coisas, passará de certo pensamento a este ou àquele outro" (E2P18Esc). (Lordon, 2015, p.70, grifo meu)

Como aponta Lordon (2015), o termo hábito é fundamental para compreender essas passagens da Ética. É por meio do hábito que determinadas 
relações entre coisas, as afecções que elas produzem e as imagens que elas suscitam são fixadas em nossas mentes, onde servirão, no futuro, como um reservatório ao qual recorreremos para interpretar novas experiências, novos encontros, novas afeções. O autor continua:

\begin{abstract}
Cada um encadeia seus pensamentos seguindo certo hábito, resultado da maneira como ordenou em seu corpo as imagens das coisas - ideia da qual se entende: 1) que o hábito é o próprio efeito da potência do corpo "deter" concomitâncias ou sucessões de afecções; 2) que "paralelamente" (simultaneamente), a mente liga suas ideias seguindo uma ordem simular e dual em relação àquela pela qual o corpo liga suas afecções; 3) que esse movimento generalizado de concatenação do pensamento não tem nada de aleatório, mas se organiza de acordo com regularidades - "hábitos", cada qual possuindo os seus próprios - que coordenam as ligações nas mesmas direções - no mesmo sentido, poderíamos dizer, jogando com a polissemia da palavra -, e que tais hábitos foram primeiramente formados pelo corpo e no corpo, que eles existem e operam como inscrições corporais - "a maneira como [cada um] ordenou em seu corpo as imagens das coisas [grifo do autor]. Em cada um constitui-se, portanto, um "hábito" hermenêutico, estrutura estratificada de esquemas concatenados orientados, dos quais uma parte é comum em uma grande escala - todo mundo, por exemplo, associa o barulho do trovão à iminência da chuva -, uma parte é comum na escala de grupos mais restritos - as associações dos camponeses são as mesmas, mas diferem daquelas dos soldados -, uma parte mais idiossincrática, formada, por exemplo, de acordo com as fixações neuróticas de uma história pessoal. Deixando de lado esta última (ainda que...), é preciso dizer o quanto a análise da formação desses "hábitos" é devedora da sociologia. Experiências comuns ou, em outros termos, afecções comuns, determinam concatenações comuns e, na sequência, hábitos hermenêuticos comuns. (Lordon, 2015, p.70-1, grifos meus)
\end{abstract}

Essas longas citações são importantes porque vão ao coração do problema do qual nos ocupamos neste trabalho. E porque reforçam a atualidade do pensamento espinosano quando olhamos, por exemplo, tanto para a sociologia de Bourdieu, da qual se ocupa Lordon, quanto da de Erving Goffman - Goffman que, por sua vez, é uma das principais referências de George Lakoff em sua abordagem da política à luz da neurologia. Na trajetória desse pesquisador americano, a relação entre mente e corpo sempre esteve presente. Ele chega a ela em sua busca pelo fundamento "material" da linguagem, que identifica, por exemplo, na relação das metáforas com as experiências do corpo num dado ambiente. Para ele, a maneira como experiências habituais produzem vínculos neurais e trilhas neuronais em nossos cérebros, modificam-nos fisicamente, influenciando de maneira radical na forma como pensamos, como reagimos diante de um acontecimento, de uma imagem, de uma cena, de uma palavra, de um discurso, de um rosto etc. Os estudos de Lakoff abrem perspectivas promissoras 
para pensarmos as relações existentes entre determinados conjuntos de palavras, imagens e narrativas e a eficácia de certos discursos políticos contemporâneos. Isso é parte importante no esforço de tentar compreender o papel e os efeitos persuasivos de certas construções retóricas - que num sentido amplo, incluem todo o arsenal da publicidade e da propaganda, mas também do jornalismo, da indústria de entretenimento e, é claro, das redes sociais - na transmissão, na disseminação, na "viralização" dos afetos políticos e, por sua vez, o papel dos afetos coletivos na constituição dos corpos políticos.

Num de seus primeiros livros (Lakoff e Johnson, 2013), escrito em parceria com Mark Johnson, Lakoff se ocupa de entender especificamente esse componente material das metáforas, que são, para ele, elementos fundamentais da linguagem. Nessa obra, os autores argumentam que o entendimento entre pessoas ou grupos depende muitas vezes da capacidade que se tem ou, no mínimo, do esforço que se empreende para traduzir experiências pessoais ou coletivas em metáforas compreensíveis - e compreensíveis quer dizer aí também sensíveis para o maior número de interlocutores. Mais do que isso. Para os autores, nosso autoconhecimento, nossa consciência de si, exige uma atenção e uma revisão permanentes do significado de nossas experiências: "envolve a construção constante de novas coerências em nossa vida, coerências que deem novo significado às velhas experiências" (Lakoff \& Johnson, 2013, p.233).

Metáforas têm origem em experiências espaciais, visuais, sensoriais. A partir dessas experiências, desdobram-se inúmeras outras, que se dão no âmbito mental - poder-se-ia dizer, com Espinosa, conforme o atributo do pensamento. As experiências, traduzidas em metáforas, palavras, imagens e conceitos, dão, pouco a pouco, origem a estruturas mais complexas que constituem precisamente aquilo que Goffman (2012) denominou quadros (frames). Os quadros funcionam como esquemas interpretativos ou modelos narrativos que ativamos de maneira inconsciente diante de situações, eventos, diante de afecções, de modo geral. Não é difícil perceber que o que Goffman define como quadro é precisamente aquilo que, nos trechos citados acima, Lordon descreve, em seus próprios termos, como “"hábito' hermenêutico" ou "estrutura estratificada de esquemas concatenados orientados" (Lordon, 2015, p.71). Os quadros são, no entanto, apenas parte desse processo de produção de sentidos. Lakoff recorre ao linguista Charles Fillmore para falar da importância dos "campos semânticos" nesse processo de produção 
de sentido. Para Fillmore, campos semânticos são definidos em relação aos quadros da experiência social. Palavras como "custo", "venda", "bens" ou "compra", por exemplo, acionam todas um mesmo quadro: o de uma situação de negócios. Nele emergem uma série de papéis - o do comprador, o do vendedor etc. -, cada um desses papéis, por sua vez, traz consigo uma especificidade de imagens e valores associados (pelo hábito, de acordo com cada ingenium). Do ponto de vista da neurologia, Lakoff (2012) argumenta que até mesmo as ações mais básicas, como agarrar um objeto, obedecem a um enquadramento e que isso pode ser observado no plano neuronal: “Os papéis são o do agarrador, o do agarrado e o da parte do corpo usada para agarrar" (Lakoff, 2012, p.23). Pode-se perceber, pela descrição dos conceitos mobilizados por Lakoff, que sua abordagem se aproxima, em muitos pontos, não apenas daquela de Espinosa, mas também daquela do segundo Wittgenstein, em que a fronteira entre semântica e pragmática torna-se cada vez mais borrada. Vimos, já aqui, o quanto essa leitura de Wittgenstein é importante para a concepção do conceito de discurso em Laclau. Para Wittgenstein, o significado é apreendido e moldado no e pelo uso e só pode emergir num determinado contexto. Um contexto, nesse sentido, nada mais é do que um quadro, se acompanhamos de perto a caracterização de Goffman (2012).

Quadros simples, argumenta ainda Lakoff (2012), agrupam-se para formar quadros mais complexos, muitos dos quais estão presentes em narrativas clássicas, que terminam por constituir o que se pode chamar de modelos arquetípicos. Não se pode subestimar o papel dessas estruturas, reforçadas, sedimentadas, fixadas pelo uso, na produção de afetos. Para o autor, sobre as narrativas simples impõem-se, muita vezes, estruturas adicionais: um protagonista, um herói, um vilão. Nessas narrativas, para cada um desses papéis, corresponde uma emoção apropriada. O hábito, a exposição reiterada a essas estruturas, nos torna mais suscetíveis às suas influências. Clichês funcionam como gatilhos afetivos. Não só clichês narrativos, mas clichês sensoriais, também. Músicas, cores, movimentos bruscos ou lentos, closes ou panoramas. Não é por acaso que certos clichês dramáticos funcionam tão bem no cinema ou na dramaturgia. Não é por acaso, tampouco, que certas cenas, as mais piegas, são, por vezes, capazes de nos comover. 
A importância disso tudo para a compreensão da política contemporânea - e da explosão populista - é óbvia. Para Lakoff, a política é uma questão de valores morais e o que está em disputa nos confronto de discursos políticos é sempre uma perspectiva sobre o que é certo ou errado. Para ele, não são os argumentos racionais, o empilhamento de dados, a guerra de informações que definem as escolhas políticas - ou, como preferiria, talvez, Laclau: não é isso que produz catexia. O que importa, para Lakoff, é sobretudo o quadro que um determinado conjunto de metáforas, narrativas e imagens é capaz de acionar. Para Lakoff, a linguagem se adequa à realidade na medida em que se adequa à nossa estrutura cognitiva: o poder das palavras reside, portanto, em ativar nosso processo de interpretação - que combina quadros, metáforas, narrativas e imagens para produzir sentimentos que nos afetam fisicamente:

Se ouvimos a mesma linguagem repetidas vezes, passamos a pensar cada vez mais nos termos dos enquadramentos e metáforas ativados por ela. Não importa se são palavras negativas ou questionamentos, os mesmos enquadramentos e metáforas serão ativados e, portanto, fortalecidos. (Lakoff, 2009, p.15)

Não é muito diferente do que aponta, por exemplo, Sarah Ahmed (2014), ao se referir ao imaginário e ao léxico mobilizados por discursos de cunho nacionalista ou xenófobo. Para ela, nessas narrativas há um alinhamento poderoso de "família", "história" e "raça" que transforma a branquitude numa espécie de "vínculo familial" que funciona para criar uma unidade - um "nós" - que se opõe a um "eles", um "outro", não-branco, descrito como "estranho", como um "corpo fora do lugar" (Ahmed, 2014, p.2). Nem é muito diferente do que, a partir do referencial lacaniano, Stavrakakis (2007) identifica na análise dos discursos nacionalistas.

Todas essas abordagens retornam, de certo modo, a uma questão crucial, colocada pela questão da causalidade imanente: não existe fora. A única "saída" disponível é sempre por dentro. Não se trata de sair de uma situação, mas de criar, inventar outra situação a partir desta. Negar a importância das estruturas, dos quadros, dos hábitos hermenêutico etc. - negar simplesmente tudo isso é a melhor maneira de manter tudo isso em funcionamento. A única forma de subverter tais estruturas é levando-as ao limite, mas sabendo que, se formos bem sucedidos, as ruínas dessas estruturas servirão de matéria prima para as novas construções. A 
política pós grito populista é sempre uma arte de "construir estradas com ruínas" (Safatle, 2004).

Essa imagem, sugerida por Vladimir Safatle num texto sobre a obra de David Lynch, é extremamente útil para descrever não só o grito populista, na maneira como ele recorre invariavelmente a estruturas gastas pelo uso, quanto para descrever a tarefa de reconstrução que, defende-se aqui, deveria suceder um corte populista bem-sucedido - ou eficaz. A maneira como Safatle descreve os personagens e as cenas de Estrada Perdida parece dizer algo sobre a forma do discurso populista, mas, sobretudo, parece indicar de onde ele tira muita de sua força.

Como em A Estrada Perdida, todos os personagens parecem falsos ou caricatos. Cada um nos dá a impressão de ter saído de um filme que já vimos: o "homem misterioso" usa pancake, maquiagem de olhos e roupa preta como qualquer vampiro barato de filme de baixo orçamento, os policiais são estúpidos como todos os policiais, o amante/cafetão de Renée, Andy, tem pele bronzeada e bigode fino como todo amante latino, isto ao menos segundo as leis de Hollywood.

Os personagens são carregados demais e às vezes parecem apenas repetir falas e desempenhar papéis que todos sabem gastos. Tudo parece ter sido reaproveitado, como em uma liquidação de antigos clichês da história do cinema que já não funcionam direito. Dessa forma, Lynch filma com ruínas da gramática do imaginário cinematográfico.

Este é um dos pontos de genialidade do filme e que diz respeito ao processo geral de criação de David Lynch. Trata-se de abrir espaço para uma experiência do real através da repetição mimética de uma realidade fetichizada. Na mão de outro cineasta, estas histórias de um mecânico que se apaixona pela amante do velho gângster ou do marido atormentado que assassina a própria mulher sem lembrar-se de nada viraria uma história trivial. Mas Lynch sabe que essas histórias não podem mais ser contadas - elas estão gastas demais - e trata-se de mostrar isto a todo momento.

A forma da estrutura narrativa nega o conteúdo da história que ela deveria suportar. É deste conflito que vem a impressão irredutivel de estranhamento próprio a Estrada Perdida. Vivemos em um mundo onde investimos libidinalmente em ruínas. Nesse sentido, Lynch nos oferece uma via de sublimação, ao se servir de um dos dispositivos maiores da arte contemporânea, cujo eixo de desenvolvimento está exatamente em forçar suas margens ao introduzir instabilidade naquilo que, de tão visto, parecia não poder significar mais nada.

O que era muito familiar deve transformar-se em estranho. Estratégia que abre espaço à experiência do real através do embaralhamento das noções de identidade e semelhança que estruturam nosso universo estável de referências (...). (Safatle, 2004, grifos meus).

Se tanto espaço foi dedicado, nos parágrafos anteriores, para descrever a armadura institucional do capitalismo na contemporaneidade, é para escapar de qualquer abordagem ingênua do potencial do populismo como forma de organização política. O que se está postulando aqui, em primeiro lugar, é que a 
eficácia do populismo como forma de organização política depende fundamentalmente do uso dessas estruturas. São elas que nos permitem responder a uma das perguntas repetidas, algumas vezes, nos parágrafos anteriores: o que cola? Se o que temos em mente, no entanto, não é reproduzir essas mesmas estruturas, se o que queremos não é simplesmente trocar os jogadores, mas mudar o jogo, é preciso que o uso dessas estruturas não produzam, no final das contas, familiaridade, mas estranhamento. Só dessa forma o grito populista deixará de ser apenas uma expressão de impotência, frente às estruturas complexas do Capitalismo Mundial Integrado, que tanto incidem sobre nossos corpos - que a elas se habituam - quanto invadem nossas mentes - e nelas habitam.

\section{6}

\section{Expressões da indignação da explosão populista}

Não é difícil compreender o papel exercido pelo quadros e narrativas que discutimos antes na recente explosão populista. Mas isso não é nenhuma novidade, não é nenhuma característica do neopopulismo. $\mathrm{Na}$ análise da retórica característica das manifestações populistas ao longo da história, é possível ver a repetição de uma série de estruturas básicas no movimento pendular dos significantes flutuantes, de um lado ao outro do espectro político (Kazin, 1998); na maneira como o oprimido pela elite pode ser tanto o branco ressentido com a perda de privilégios, que acredita ter sido usurpado, seja pelas políticas de direitos civis, seja pela imigração, quanto pode ser o operário que perdeu o emprego nas fábricas que não resistiram à concorrência do mercado internacional, à invasão do mercado pelos produtos chineses; na maneira como, de um lado ou de outro, a indignação parece sempre indicar uma impotência, uma barreira, um entrave imposto pelo sistema, pela institucionalização extrema, pela ossificação da armadura institucional. O populismo dá forma e, por vezes, força ao afeto da indignação. Afeto que resulta, por sua vez, dos hábitos do corpo e da mente, fixados pela experiência de viver sob um determinado meio. É nesse sentido que o populismo, menos que uma solicitação - do que o encaminhamento de uma demanda clara e distinta, formulada numa linguagem compreensível - é algo que se manifesta como grito. Apropriando-se de maneira um tanto quanto selvagem do conceito lacaniano, pode-se dizer que o populismo é algo da ordem da 
lalangue: linguagem não linguística, pré-simbólica que se encontra antes da linguagem e depois da linguagem. Algo da ordem do balbucio infantil, expressão de algo que emerge ali, naquele espaço obscuro que fica entre a jouissance e a linguagem, entre necessidade e demanda, o não-comunicável na linguagem, aquilo que, por meio da ambiguidade ou da homofonia, revela os aspectos afetivos que nela persistem e que nos afetam, sobretudo, por tudo que trazem à tona, "por meio de efeitos que são afetos" (Lacan apud Stavrakakis, 2007, p.95).

Deixando Lacan de lado, pode-se dizer, com Espinosa, que o grito populista é um signo da indignação. O que ele põe em cena é "o limite do poder de afetar de uma instituição" (Lordon, 2015, p.81). O que sai de cena, para a indignação entrar, é o obsequium, o respeito, a observância dos protocolos, o circuito de afetos (Safatle, 2016) que dava sustentação às instituições: é a antessala da sublevação, da revolta, da sedição.

E se tem algo que a indignação produz bem é ruína. Até o momento, o que Donald Trump e o Brexit produziram foram ruínas. Investiram contra as bases podres do capitalismo democrático, em cima das quais se assentava a hegemonia neoliberal - que, no entanto, ainda se sustenta. Muito possivelmente porque sobrevive, sobretudo, em nós. Porque a ela nos habituamos, porque ela nos habita. Essa foi, possivelmente, a grande façanha do realismo capitalista, como descrito por Mark Fisher (2009), um conceito construído a partir de uma ideia de esgotamento da imaginação, produzido pela internalização generalizada do bordão thatcheriano - não há alternativa - e do vaticínio de Jameson, popularizado também por Zizek, de que hoje em dia é mais fácil imaginar o fim do mundo do que o fim do capitalismo. Trump, Brexit e tantos outros fenômenos políticos recentes parecem surgir saturados desse sentimento. É como se a recente explosão populista, como se o grito populista, flertasse com um desejo de aniquilação, dirigido contra o "espírito do capitalismo" em nós. Como o possuído que, por vezes, ao debater-se, bate no próprio corpo, se violenta.

Escrito no auge da "crise" de 2008, o livro de Fisher (2009) começa remetendo a Filhos da Esperança, o filme de Alfonso Cuarón. Trata-se de uma distopia que, diferentemente de filmes clássicos do gênero, como Mad Max, não se passa num cenário catastrófico, desértico, uma terra devastada, mas num ambiente que lembra muito o urbano contemporâneo, fundo sobre o qual o personagem principal se desloca. 
O mundo que o filme retrata lembra mais uma extrapolação ou uma exacerbação do nosso mundo do que com uma alternativa. Nesse mundo, assim como no nosso, o ultra-autoritarismo e o Capital não são, de modo algum, incompatíveis: campos de concentração e franquias de cafeterias famosas coexistem tranquilamente. Em Filhos da Esperança, o espaço público está abandonado, servindo de depósito de lixo, entregue aos animais selvagens. (Fisher, 2009, p.2)

No plot principal de Filhos da Esperança, está uma humanidade às voltas com o estranho caso da esterilidade. De repente, sem nenhum motivo aparente, sem nenhuma explicação plausível, as crianças simplesmente pararam de nascer.

É evidente que o tema da esterilidade deve ser lido metaforicamente, como deslocamento de outro tipo de ansiedade. Quero dizer que a ansiedade pede para ser lida em outros termos. A questão que o filme coloca é: quanto tempo pode durar uma cultura que persiste sem criar o novo? O que acontece quando os jovens se tornam incapazes de surpreender?

Filhos da Esperança tem relação direta com a suspeita de que o fim já chegou, com o pensamento de que é bem possível que a promessa de futuro que alimentamos seja apenas uma promessa de reiteração e restauração. Será que já não existem mais rupturas ou "choques de novidade" por vir? Essas ansiedades tendem a uma oscilação bipolar: o "messianismo fraco", que espera que exista alguma coisa nova pelo caminho, sucumbe e dá lugar à convicção morosa de que nada de novo pode acontecer. O foco muda da Próxima Grande Coisa para a última grande coisa - há quanto tempo aconteceu? Quão grande ela foi? (Fisher, 2009, p.3)

Não é precisamente desse "messianismo fraco" que parecem ensejar os recentes gritos populistas, dos quais temos nos ocupado aqui? Não é “a convicção morosa de que nada pode acontecer" que faz com que, por exemplo, poucos meses depois da eleição de Donald Trump, o candidato republicano já ostente um dos piores índices de popularidade para um começo de governo nos últimos anos? Não é essa constante frustração que faz com que, após eventos como esse, nos vejamos obrigados a reconhecer que nada mudou - para seguir em busca da "próxima grande coisa", num caminho que parece conduzir, mais cedo ou mais tarde à anedonia, à incapacidade mesmo de sentir qualquer prazer?

Enquanto estiverem impregnados de realismo capitalista, os gritos populistas não serão capazes de ir muito longe. Ainda que a armadura institucional do capitalismo contemporâneo, construída ao longo dos últimos trinta anos de retórica e biopolítica neoliberal, esteja hoje em frangalhos. É possível que o capitalismo democrático, que vigorou plenamente nas economias e não raro, grotescamente nas periféricas -, esteja apenas comprando tempo, como 
sugere Streeck (2012). Ninguém parece saber, no entanto, o que fazer diante disso.

O que parece evidente, por outro lado, é que a extrema direita, repaginada agora na Alt-Right, parece estar se divertindo bastante nesse novo contexto. É isso que transparece, por exemplo, na análise recente de Angela Nagle (2017). A autora se dedica a investigar de que forma a chamada guerra cultural, travada nas redes entre a chamada esquerda progressista, ligada às lutas identitárias, e a direita conservadora, opera numa espécie de relação simbiótica, onde uma se alimenta da outra. Em seu livro, a autora defende a hipótese que o discurso da Alt-Right se constituiu como resposta à ascensão dos chamados social justice warriors, os militantes das redes sociais vinculados às pautas progressistas, sempre prontos a submeter toda manifestação pública a um cuidadoso escrutínio, em busca de manifestações mais ou menos explícitas de machismo, homofobia, transfobia, racismo ou preconceito, de forma geral. Para Nagle, a Alt-Right teria gestado sua estratégia de guerra nos fóruns do 4Chan, uma rede social muito apreciada por nerds, gamers e ratos de internet, que, segundo ela, reúne uma cultura eminentemente machista, com uma espécie de ressentimento orgulhoso, um espírito de "trollagem", para usar o termo próprio das redes, uma vontade de "zueira pela zueira", de bagunçar só pelas risadas - for the "lols" (apreviatura de laugh out loud, popularizada em memes que circulam na rede). Para a autora, o que se deu, nesse contexto de guerras culturais, foi uma apropriação dos discursos, posturas, comportamentos e performances transgressoras, popularizados sobretudo no âmbito da New Left, anos 1960, por parte dessa geração 4Chan. A obscenidade, a ofensa, o combate ao status quo - associado pelas falanges do 4Chan à esquerda progressista, que a autora associa principalmente à plataforma Tumblr - teriam se tornado armas poderosas na mão da chamada Alt-Right, que se consolidou graças à organização de uma vasta rede, especializada, entre outras coisas, em disseminar discursos de ódio e teorias da conspiração e, também, em perseguir, escrachar, destruir reputações ou simplesmente "trollar" seus adversários políticos. Nagle (2017) vê em Trump um produto desse meio. E atribui, ao menos em parte, a vitória de Donald Trump ao engajamento desses grupos na campanha do republicano.

É evidente que não se pode atribuir a vitória de Trump aos votos dessa parcela da população americana. Nem a esquerda Tumblr, nem a direita 4Chan 
têm essa representatividade. O que é preciso compreender, no entanto, é de que maneira esses grupos ajudam a dar forma ao discurso populista vocalizado por Donald Trump em entrevistas, debates e comícios que tiveram seu alcance potencializado pela desproporcional cobertura midiática recebida pelo então candidato. Quando se tem em mente o argumento de Lakoff (2012), o de que a repetição exaustiva dos mesmos discursos, dos mesmos conjuntos de palavras, das mesmas imagens, reforçam determinados quadros, independente do conteúdo dessas palavras, é fácil compreender a importância que tiveram nos resultados da eleição tanto a atuação dessa rede de "colaboradores" de campanha, quanto da hiperexposição midiática que a aura transgressora e a obscenidade do discurso de Trump estimularam. Não foi a extrema direita que deu a Trump os votos que ele precisava para se eleger. Os eleitores de Trump não são um imenso exército de fascistas. O que os nerds do 4Chan fizeram foi contribuir para ativar determinados quadros e levar adiante determinadas narrativas capazes de suscitar determinados afetos e levar, dessa forma, milhões de eleitores a optar pelo republicano como aquele capaz de representar rua indignação, a despeito de todo discurso apocalíptico da mídia. Trump e o Brexit são, nesse sentido, só mais uma prova de que o populismo funciona como forma produzir coalizão de forças desejantes. Mas também de que seu sucesso depende de como ele é capaz de lidar, ao mesmo tempo, com os quadros da experiência social, os hábitos hermêuticos, e com as estruturas globais que produzem afetos locais, com o Capitalismo Mundial Integrado que, ao mesmo tempo, nos habitua e habita. 


\section{Conclusão: Das ruínas às estradas (ou um pitaco sobre geringonças, manipulação do oikos e espaços de "descapitalização")}

“A poesia persa define esse movimento
como o curso de um riacho num prado.
A água nunca segue linha reta. A
essência de seu movimento é o
obstáculo. O que obstrui a água a obriga a se movimentar. Essas curvas e meandros, que fazem a beleza dos riachos, provêm de seu encontro com obstáculos"

Abbas Kiarostami

O que deu origem a esta pesquisa de mestrado foram os eventos de Junho de 2013, no Brasil. Hoje, compreendo-os como uma afecção global que produziu, num ingenium (no caso, o meu) um afeto local - e me pôs em movimento. Minha complexão afetiva não me conduziu ao ativismo político, mas de volta à universidade, depois de um longo período imerso num espaço em que convivem o velho e o novo espírito do capitalismo: uma empresa de petróleo. Isso, obviamente, tem muito a dizer sobre a escolha dos objetivos e das perspectivas a partir das quais eles foram abordados ao longo deste trabalho.

Entre os eventos de Junho de 2013 e o início do mestrado, o Brasil passou por uma eleição presidencial. Nela, a candidata reeleita, Dilma Rousseff, saiu vencedora, opondo sua plataforma desenvolvimentista - que defendia uma forte presença do Estado na economia, como saída para crise econômica - à proposta neoliberal, que atribuía aos seus dois principais adversários, Aécio Neves e Marina Silva. Entre essa eleição e o momento da escolha de meu objeto de pesquisa, vi a presidente eleita praticar o que muitos classificaram como um “estelionato eleitoral". Dilma abraçou, imediatamente após a eleição, uma série políticas de austeridade fiscal que, em linhas gerais, pareciam não diferir muito 
daquelas defendidas pelos adversários derrotados. Foi mais ou menos nessa época que esta actuosa essentia que vos fala foi submetida a uma série de afecções e afetos que levaram à suspeita de que a estrutura do Capitalismo Mundial Integrado - CMI (Guattari e Rolnik, 1986) era determinante para a forma com que eu percebia uma série de fenômenos políticos atuais.

Pouco antes de defender o projeto, na qualificação, meu interesse foi subitamente capturado pelas prévias da eleição norte-americana e pelo embate entre Donald Trump e Bernie Sanders. Nessa época, eu já tinha tomado conhecimento das teses de Ernesto Laclau sobre o populismo e não conseguia não ver muitos dos mecanismos descritos por ele em ação naquele pleito, que produzia, então, uma aparente reviravolta nas instituições democráticas da economia mais poderosa do mundo. O crescimento de Bernie Sanders me entusiasmava especialmente. Donald Trump era considerado, na época, para a maioria dos analistas, um aventureiro, um franco atirador absolutamente incapaz de obter, nas eleições majoritárias, o sucesso que fazia nas prévias. Essa leitura, ao que tudo indica, foi determinante para que o establishment democrata, na época, favorecesse a candidatura da democrata Hillary Clinton, cuja longa experiência em Washington poderia ser contraposta à inexperiência do magnata Donald Trump. Bernie Sanders era, para muitos democratas, uma aposta arriscada demais. De resto, muitos achavam que tinha chegado a vez de Hillary, que o fato de ser mulher era um ponto a favor, que o carisma de Obama, com seus altos índices de aprovação, poderia favorecê-la e que sua boa aceitação entre as comunidades afro-americanas era a cereja do bolo que faltava para atrair o eleitorado progressista.

Como sabemos, não foi. Com Bernie Sanders fora do páreo, Trump se tornou o único candidato capaz de dar forma à indignação de uma parcela significativa do eleitorado americano, inclusive junto a uma fração que ainda se ressentia dos efeitos do estouro da bolha imobiliária e da crise econômica que a sucedeu. Ao mesmo tempo, a derrota de Sanders, nas prévias, acabou por reduzir o interesse pela corrida presidencial por parte dos jovens eleitores, mais afinados com a recente ascensão das ideias de esquerda nos Estados Unidos, sobretudo na esteira do Occupy Wall Street. Ao escolher o populismo como objeto de pesquisa, procurei acompanhar esse movimento todo com o máximo de atenção. Algo nem sempre muito fácil, devido à avalanche de informações que eram produzidas 
diariamente pela mídia, que cobria apaixonadamente a corrida. Como se não bastasse, o cenário brasileiro nunca saiu completamente de meu horizonte. Foi impossível não se deixar afetar pelos eventos que conduziram ao impeachment da presidente Dilma Rousseff e a crise institucional que veio em seguida - crise esta que hoje atribuo ao movimento centrífugo dos afetos.

Ao longo da pesquisa, a observação desses fenômenos contemporâneos parecia deixar muito claro que Laclau acertava em cheio quando via no populismo uma reação ao que ele chamava de institucionalismo extremo. A sensação que eu tinha, no entanto, era de que esse institucionalismo não estava mais no Estado, mas numa estrutura maior. Algo me levava a crer que, sem levar em conta as estruturas globais, a mobilização (política) dos afetos locais (ainda que esse local fosse tão grande quanto um país de dimensões continentais, como o Brasil) ainda que bem sucedida na mobilização de significantes vazios e na construção de cadeias de equivalências entre demandas heterogêneas - se defrontaria, inevitavelmente, com duas dificuldades que me pareciam incontornáveis: de um lado, a estrutura do CMI; de outro, a presença dessas estruturas em nós. Esses dois elementos sempre me pareceram, ao longo de toda a pesquisa - e continuam me parecendo - o motivo dessa sensação de que, nos levantes populistas, tudo muda para permanecer igual. É preciso reconhecer, no entanto, que essa é uma ideia inadequada. Mais correto seria dizer que nem tudo muda e nem tudo permanece igual, mas, parafraseando Leibniz, dizer que de tudo que muda, algo permanece. E esse sentido, o que determina a eficácia ou o fracasso de um levante populista, em sua tentativa de reconfigurar o social, é a razão entre o que muda e o que permanece - e para quem.

No caso brasileiro, se reconhecemos a presença da lógica populista no movimento do impeachment - uma parte que passa a representar o todo (a classe média, majoritariamente branca, que se apresenta como a totalidade do povo brasileiro) e se organiza em torno de um significante vazio (o antipetismo) para derrotar um adversário que personifica o institucionalismo extremo (o Partido dos Trabalhadores) - é fácil perceber que, para a grande maioria da população, o que muda é o fato de agora ter que lidar com uma série de direitos hoje ameaçados; o que permanece é a desigualdade brutal entre a minoria mais rica e a maioria mais pobre da população. Coisas que, no entanto, ninguém poderia afirmar que não aconteceriam se o impeachment não tivesse acontecido, afinal, nos primeiros 
meses de governo da presidente reeleita, o que se viu foi a tentativa de implantar uma série de medidas de austeridade que, hoje, o governo de Michel Temer leva adiante com uma rapidez assustadora, a despeito de sua impopularidade.

Mas o que dizer da juventude que foi às ruas em 2013, mas não fez parte das multidões de amarelinhos que, com suas camisas da CBF, ocuparam-nas em 2014, para pedir a cabeça de Dilma? Nesse jogo entre "coxinhas" e "petralhas" que virou a política brasileira, onde foi parar a "geração Junho"?

Num artigo bastante perspicaz, Rodrigo Nunes (2014), defende que Junho de 2013 pode ser compreendido como resultado de uma série de manifestações menores que, nos anos anteriores, vinham mobilizando vários grupos ligados à esquerda em torno de diversas causas. Nunes (2014) acredita que foram as forças acumuladas nesse conjunto de manifestações e movimentos que, em 2013, convergiram para formar, ao menos em sua origem, aquele acontecimento de grande magnitude, que incendiou o país. Nunes (2014), recorrendo ao pensamento de Karl Mannheim, chama de "geração-junho" a geração-acontecimento gestada no calor daqueles dias.

Entre os movimentos que precederam Junho, Nunes identifica os protestos e mobilizações contra a remoção de famílias e comunidades para dar lugar às obras da Copa do Mundo de 2014 e das Olimpíadas de 2016, no Rio; contra a especulação imobiliária e a expansão da fronteira agrícola, que avançou em direção às áreas de preservação ambiental e reservas indígenas e quilombolas; contra a política desenvolvimentista dos governos Lula e Dilma, que tiveram nas obras da usina de hidrelétrica de Belo Monte e na transposição do rio São Francisco duas de suas faces mais emblemáticas; e, de modo geral, contra a política de alianças do PT com setores conservadores da política brasileira, ligados ao agronegócio e ao setor evangélico, que impediu o avanço de muitas políticas progressistas e, por vezes, exigiu o sacrifício de bandeiras históricas do partido, como a luta pelos direitos reprodutivos e de orientação sexual, bem como a reforma agrária. E por aí vai. Rodrigo Nunes é muito feliz ao resumir essa miríade de protestos a "basicamente dois conjuntos de problemáticas":

(...) as reivindicações provenientes dos que foram de maneira sistemática excluídos do desenvolvimento quantitativo da última década, isto é, daqueles que não apenas não se beneficiaram com o crescimento econômico, como foram diretamente 
prejudicados por ele; e as demandas por um desenvolvimento qualitativo. (Nunes, 2014, p.18)

Por desenvolvimento "qualitativo", Nunes se refere não só à melhora dos serviços públicos capazes de acompanhar o novo status econômico e geopolítico conquistado pelo país ao longo da gestão petista, mas à demanda por um modelo alternativo de desenvolvimento, capaz de combinar não apenas uma outra relação entre o estado e sua população - especialmente a parcela mais pobre dessa população; e - além da garantia, claro - a criação de direitos que resultassem em maior participação política e num acesso aos commons, os bens comuns, em especial, o meio ambiente ${ }^{57}$.

Acredito que o que levou a geração Junho a ser, por assim dizer, escanteada do jogo político brasileiro não foi apenas o fato de ter se estabelecido entre ela e a geração anterior da esquerda, hoje reunida sobretudo em torno do Partido dos Trabalhadores, um antagonismo que enfraqueceu ambas, impedindo que fosse estabelecida entre duas diferentes demandas uma cadeia de equivalências, que os unisse na luta contra as forças conservadoras que, no pós-Junho, se organizaram em torno dos movimentos que lideraram as manifestações pelo impeachment. Acredito ainda que a geração Junho, como descrita por Nunes (2014), foi incapaz de embrulhar suas pautas num discurso capaz de produzir catexia junto ao conjunto mais amplo da população. Não só entre setores da classe média que se aliaram ao impeachment, mas também junto aos setores mais carentes da população, concentrados tanto nas periferias dos grandes centros urbanos quanto nas pequenas cidades do interior. Atribuo essa incapacidade, em parte, tanto à dificuldade encontrada para ativar os quadros da experiência social desse imenso contingente da população, quanto ao fato que, por vezes, não foram levados suficientemente em conta a pressão exercida por algumas das expressões mais básicas do conatus, o esforço para perseverar no ser que, para a maioria absoluta da população brasileira, consiste em ter um emprego que lhes dê acesso ao dinheiro. Essa me parece uma questão incontornável. É possível que ajude a explicar, por exemplo, o sucesso de Lula, que persiste, apesar da enxurrada de

\footnotetext{
57 “Que tenha sido o transporte público a faísca que acendeu a insatisfação que se acumulava é relativamente contingente, ao mesmo tempo em que faz muito sentido, já que se trata de um tema universalmente compartilhado e um exemplo claro de que algumas dimensões elementares da vida cotidiana da maioria da população não mudaram nada, apesar do sucesso internacional do país na última década." (Nunes, 2014)
} 
acusações de corrupção e críticas de todo tipo, ainda hoje. E não só entre as classes mais baixas. Entre determinados setores da classe média também. Setores para os quais o governo petista fez uma série de ofertas ao conatus, por exemplo: funcionários públicos que viram seu salário crescer significativamente, professores que puderam observar mudanças sensíveis na estrutura das universidades, alunos e pesquisadores beneficiados com bolsas de estudo, políticas de cotas e programas como o Prouni. Essas ofertas ao conatus não estava ao alcance da geração Junho fazer. Mas é possível que a "velha esquerda", que por um tempo se apegou ao "Volta, Dilma" e hoje deposita todas as esperanças em "Lula 2018", também não pudesse.

Não apenas por conta dos reflexos da crise econômica, que demoraram, mas se fizeram sentir por aqui. Mas sobretudo pela baixa no preço das commodities, motivada, em parte, pela redução do ritmo do crescimento chinês, que até então vinha consumindo vorazmente toda matéria prima que produzíamos. Como disse Paulo Eduardo Arantes, em artigo publicado no Correio da Cidadania, em 2015: a "paz social" promovida por Lula, em sua versão "Paz e Amor", não é mais possível.

\begin{abstract}
Numa palavra, a fórmula mágica da paz simplesmente se esgotou, como todos os demais recursos que alimentaram o jogo de cena da trégua lulista. Todo mundo sabe de trás para frente quais eram esses recursos: o consenso das commodities, o acesso facilitado ao crédito e consequente endividamento popular em grande escala, o consumo de massa puxado por uma descomunal e caótica expansão urbana etc. (...).

Como resumiu Camila Moreno, "nós estamos dentro da China, e a China está dentro de nós". Um dia ainda nos daremos conta de que o drama de época que está se encerrando agora foi representado em dois palcos distintos, transitando do finado Consenso (financeiro) de Washington ao não menos fantasmagórico Consenso (extrativista) de Pequim (...). (Arantes, 2015)
\end{abstract}

China que "dá em Chico, dá em Francisco". Problema semelhante a esse que se abateu sobre o lulopetismo já está sendo enfrentado, hoje, por Donald Trump. Não dá pra simplesmente se livrar da China, que financia hoje grande parte da a dívida americana, comprando títulos do Tesouro enquanto, ao mesmo tempo, inunda o mercado interno com seus produtos. Não dá tampouco para, de uma hora pra outra, sair da Nafta. O discurso nacionalista, mobilizado pelo populismo de direita, é, também ele, impotente diante da imensa máquina 
capitalista. Por mais estrago que faça, no plano dos direitos civis. Por mais ameaças que ofereça às conquistas das lutas identitárias nos últimos anos...

É nesse ponto que o populismo emperra. É nesse ponto que o ceticismo de Jameson parece fazer sentido. O grito populista, até o momento, parece não ter feito muito mais do que de nos distrair do "tema principal que é a natureza e a estrutura mesma do capitalismo" (Jameson, 2010). Laclau estava certo em muitas de suas conclusões. O populismo parece ser, realmente, uma lógica do político. O populismo parece ser, realmente, uma excelente ferramenta de organização política. Mas além disso, bem... tem outras coisas. Para que os problemas apontados por gente como Streeck, Pikkety, e mesmo Lordon, não permaneçam, não basta um novo arranjo político: é preciso um novo arranjo políticoeconômico: é preciso "existir soluções econômicas melhores, e marxistas e esquerdistas têm que se concentrar nisso" (Jameson, 2010).

Mas quais seriam essas soluções econômicas melhores? Essa é a pergunta da Esfinge, que ora nos devora. E creio que a resposta para ela só pode emergir como algo da ordem de uma experimentação tateante. Renda Básica Universal? Talvez. Mas como, na prática, isso funcionaria? Como seria financiada, levando em conta, é claro, o caráter integrado do capitalismo contemporâneo? Como funcionaria num país de dimensões continentais, como o Brasil? Daria para financiar a Renda Básica Universal taxando as grandes fortunas? Ou criando um imposto sobre robôs, dada a perspectiva de crescimento da automação, que se anuncia? Mas e se isso produzisse "fuga de capitais"? Se mexesse demais com o "humor do mercado"? E se, e se, e se...

Impossível dar conta de todas as variáveis. Mas, se queremos soluções econômicas melhores, é preciso que nos debrucemos sobre esses problemas, como esquerdistas, como marxistas, mas - trilha de suspense agora - como liberais, também... como neoliberais, talvez. E por liberais e neoliberais não me refiro, obviamente, aos capitalistas, nem, possivelmente, aos CEOs e executivos das grandes corporações. Esses jogam outro jogo. Falo daqueles que, por algum motivo, acreditam que poderão jogar esse jogo um dia, embora as chances disso acontecer, sejam hoje, para a maioria deles, cada vez mais improváveis. É que é bem possível que, no futuro que se avizinha, todos os gatos sejam pardos do lado de cá do $1 \% \ldots$ 
De certo modo, é nesse sentido que expressões recentes do populismo, à esquerda do espectro político, parecem apontar. A juventude inglesa pós-Brexit parece dar sinais de reação, voltando a trazer o futuro para o centro do debate político e encontrando potência de catexia em temas como a própria Renda Básica Universal, mas também no aparentemente utópico Fully Automated Luxury Communism (FALC) - algo que só podemos traduzir, toscamente, como "comunismo de luxo totalmente automatizado" (Dossiê Corbyn, 2017). As perguntas quanto às questões práticas envolvidas na realização dessas utopias persistem - e creio que devem ser, o tempo todo, recolocadas. Mas é preciso reconhecer que elas sinalizam para a possibilidade de um discurso populista forte, capaz de produzir catexia em torno de temas que, ao menos a princípio, põem em jogo o espectro da emancipação para produzir deslocamentos. Esse movimento pode representar um primeiro passo numa tentativa de nos livrarmos do realismo capitalista - uma tentativa de dar início à construção de estradas a partir das ruínas.

Digo isso porque esse imaginário do progresso tem, também ele, um quê de ruína. Esse aceno com a instauração de um paraíso na terra não é recente. Tem mesmo algo de escatológico, que remete, em grande medida, a uma narrativa arquetípica, uma narrativa de redenção, de salvação coletiva. Mas o que quero dizer aqui é: tudo bem. Para colar, o discurso populista precisa mesmo recorrer aos recursos que têm à mão: as ruínas, os clichês, os lugares comuns do imaginário coletivo. É isso ou o realismo capitalista. Importa, no entanto, não perder o passo seguinte. Importa, também, que esse recurso aos clichês deixe ainda um espaço para o estranhamento.

E o estranhamento é necessário, sobretudo, porque o imaginário progressista, esse imaginário prometeico de quem tem os olhos fitos no futuro, tem levar em conta a possibilidade de um futuro nada luxuoso com que nos acena o antropoceno. Não podemos perder de vista o fato de que, talvez, a utopia que move esse populismo precise lidar, mais cedo ou mais tarde, com o distópico. É que, em paralelo à máquina capitalista que acelera a automação, temos o movimento de Gaia. E dependendo de para onde ela se mover, pode até ser que luxo seja apenas sobreviver.

Para produzir esse estranhamento, creio que temos algo a aprender com os insights de Isabelle Stengers (2005). Precisamos aprender a - e perder o pudor de 
- manipular; precisamos aprender dispor o oikos de outras maneiras; e é preciso aprender a fazer isso tirando vantagem da propensão das coisas: precisamos, em outras palavras, de um pensamento focado na eficácia, que nos permita agir no espaço entre ethos e oikos, para que novas possibilidades possam emergir daí. Mas como intervir nesse oikos, tão colonizado pela “oikonomia"? Tão colonizado, digamos logo, pelo capital? Eu digo: não tenho resposta - e já sinto a Esfinge arrancar de mim outro naco de corpo (e de pensamento, pra respeitar "o paralelismo"). Mas tenho, claro, um palpite.

O palpite é o seguinte: a única forma avançar na direção de uma resposta é, como diz a música da moda: des-pa-ci-to. E o que quero dizer com esse gracejo é que a descolonização do oikos passa, acredito, pela criação de espaços de transição, de áreas de fronteira, de zonas de passagem. Espaços que talvez funcionem, num primeiro momento, como geringonças. Fiz questão de me referir aqui à belíssima palavra portuguesa utilizada para classificar a aliança de centro esquerda que hoje tem permitido à economia portuguesa crescer em meio à depressão europeia, mas não acho que essas geringonças devem existir apenas no plano macroeconômico. Creio que o grande desafio é multiplicar geringonças no nível molecular, para usar conceito de Deleuze e Guattari. Geringonças como espaços de "descapitalistização" capazes atender às necessidades mais básicas do conatus, antes de alimentá-las com utopias.

Acredito que a melhor maneira ilustrar o que quero dizer com isso é por meio de uma comparação que, a princípio, vai parecer (e talvez seja mesmo, mas sigamos com ela) meio esdrúxula: esses espaços de "descapitalistização" deveriam funcionar mais ou menos como funcionam certas comunidades religiosas, mais precisamente, mais ou menos como operam hoje as igrejas neopentecostais. Não, não acho que devamos pregar uma salvação pelo dinheiro, nem adaptar a "ética protestante" ao espírito do "novo capitalismo" - algo que muitas dessas igrejas fazem. Refiro-me aqui ao "paralelismo" que existe na atuação dessas igrejas. Na maneira como "a palavra" que elas levam aos fiéis, na maioria das vezes, vem junto com o "pão": junto com uma rede de segurança, um laço de solidariedade, uma ajuda com as questões práticas, de sobrevivência, de vida em sociedade: como arrumar um emprego, onde fazer amigos, onde - por que não - encontrar um amor? Tudo isso faz parte da arte de manipular um oikos para produzir um ethos. 
Acredito que outro ponto importante, nesse processo, um ponto com o qual, ao menos a princípio, as igrejas neopentecostais (parte delas, pelo menos) parecem lidar relativamente bem é com as contradições do "fiel". É aprender a aceitar as contradições que experimentamos como aspecto fundamental da experiência de viver sob o signo do capitalismo. Só assim será possível produzir espaços de "descapitalistização" eficazes: é preciso aprender a lidar com o capitalismo que habituou e habita o outro - e reconhecer que esse mesmo capitalismo igualmente nos habituou e nos habita: o capitalismo não tem fora. É importante, no entanto, não seguir o exemplo neopentecostal tão de perto. Essa relação com as contradição não precisa vir acompanhada de espetáculos de exorcismo ou de autoflagelação. Talvez encontremos maneiras mais interessantes de lidar com isso no paganismo. Ou em Espinosa. Quero dizer: é preciso entender que nem todo interesse, nem toda ambição, nem toda vaidade é sintoma de capitalismo. É preciso olhar os "fiéis" não como eles deveriam ser, mas como são. E talvez eles não sejam, não queiram ser e nem devam ser... de esquerda, socialistas ou comunistas. Querer isso é querer já um ethos definido: um telos. $\mathrm{O}$ que sugiro aqui, neste palpite, não é a definição de um telos, mas a ousadia de manipular o oikos para produzir um ethos que favoreça um circuito de afetos mais felizes. Não dá pra saber ao certo como será esse ethos. Insisto: é algo da ordem de uma experimentação tateante.

Otimismo, tenho que dizer, não é meu forte. Tenho absoluta convicção de que qualquer tipo movimento nesse sentido encontrará obstáculos e resistências brutais, por parte do Estado e do Capitalismo Mundial Integrado. Mas, até aí, nada de (muito) novo sob sol... Isso só reforça a necessidade de que que a luta aconteça, também, no plano molar, que mencionei, anteriormente, em alguns exemplos, de Sanders e Corbyn à Renda Básica Universal. Apesar de ter recorrido ao exemplo das igrejas neopentecostais, sei que existem, espalhadas pelo mundo, inúmeras geringonças diversas com potencial "descapitalistizador". E, nesse sentido, é possível que Franco Berardi (2017) aponte numa direção interessante, quando fala na necessidade de criar uma "plataforma" para conectar iniciativas dispersas, pelo mundo todo, que nos restituam o poder de criar um futuro para além do capitalismo. A consolidação de redes capazes de construir relações mais potentes seremos, quanto mais relações estabelecermos - é um aspecto que não se pode perder de vista. Afinal, não se combatem estruturas globais atuando 
apenas localmente. É preciso fundar muitas igrejas, digo, muitos espaços de “descapitalistização" empoderadora. A questão, me parece, é compreender que não se trata só de uma luta por corações e mentes: é uma luta que envolve corações (afetos, sentimento), mentes (ideias, imaginários, discursos) e corpos (afecções).

Em linhas gerais, acho que era mais ou menos isso que eu queria dizer o tempo todo. 


\section{6 \\ Referências bibliográficas}

AHMED, Sara. Cultural Politics of Emotion. 2ed. Edinburgh: Edinburgh University Press, 2014.

ALTHUSSER, Louis. A corrente subterrânea do materialismo do encontro (1982). Crítica Marxista (Editora Revan) 1, n.20, 2005. p.9-48.

BATAILLE, Georges. A parte maldita. Belo Horizonte: Autêntica, 2013.

BERARDI, Franco. The Age of Impotence and the Horizon of Possibility. Londres: Verso, 2017.

BERAN, Dale. Medium. 14 fevereiro 2017. Disponível em: https://medium.com/@DaleBeran/4chan-the-skeleton-key-to-the-rise-of-trump624e7cb798cb. Acesso em: 2 mai 2017.

BOLTANSKI, Luc; CHIAPELLO, Ève. The new spirit of capitalism. Londres: Verso, 2005.

BROWN, Wendy. Critical Essays on Knowledge and Politics. New Jersey/Oxfordshire: Princeton University Press, 2005.

Undoing the demos: neoliberalism's stealth revolution. New York: Zone Books, 2015.

BRYANT, Levi; SRNICEK, Nick; HARMAN, Graham. Towards a Speculative Philosophy. In: (eds) The speculative turn: continental materialism and realism. Melbourn: re.press, 2011.

CASTORIADIS, Cornelius. Figures of the thinkable. Stanford: Stanford University Press, 2007.

CAVA, Bruno. Os batalhadores brasileiros: nova classe média ou nova classe trabalhadora? Revista Lugar Comum \#40. Uninômade. 10 dezembro 2013. Disponível em: http://uninomade.net/lugarcomum/40/ Acesso em: 10 mai 2017.

CHAVES, Wilson Camilo. O Estatuto do Real em Lacan: dos primeiros escritos ao Seminário. Paidéia, n.34, v.16, 2006. p.161-8.

CITTON, Yves. Populism and the empowering circulation of miths. Edição: nail010 publishers. Open 20: The Populist Imagination on the Role of Myth, Storytelling and Imaginary in Politics, n.20, 2011.

CLARK, T. J. For a left with no future. New Left Review, 2012 p.55-75.

DELEUZE, Gilles. A ilha deserta e outros textos. São Paulo: Iluminuras, 2006.

; GUATTARI, Felix. Mil Platôs: capitalismo e esquizofrenia. v.3. 5 vols. São Paulo: Editora 34, 1996.

Editora $34,2007$.

Mil Platôs: capitalismo e esquizofrenia. v.5. 5 vols. São Paulo:

O Anti-Édipo. São Paulo: Editora 34, 2010.

O que é filosofia? Rio de Janeiro: Editora 34, 1992.

DERRIDA, Jacques. Specters of Marx: the state of debt, the work of mourning and the new international. London/New York: Routledge, 1994.

DURIGUETTO, Maria Lúcia. A questão dos intelectuais em Gramsci. Serviço Social e Sociedade, n. 118, abr/jun 2014. p.265-93.

DUROZOI, Gerárd; ROUSSEL, André. Dicionário de Filosofia. Campinas: Papirus, 1993.

Žižek, Slavoj. Como ler Lacan? Rio de Janeiro: Jorge Zahar, 2006.

Against the Populist Temptation.” Critical Inquiry 32 (Spring 2006), 2006. p551-574. 
Em defesa das causas perdidas. São Paulo: Boitempo, 2011.

Interrogating the real. Editores: Rex Butler e Scott Stephens. New York:

Continuum, 2005.

O ano em que sonhamos perigosamente. São Paulo: Boitempo, 2012.

The return of publicly vulgarity. Newsweek. 2 dezembro 2016.

Disponível em: http://www.newsweek.com/return-public-vulgarity-425691. Acesso em: 30 jul 2017.

LACLAU, Ernesto. The making of political identities. London/New York: Verso, 1994.

FISHER, Mark. Capitalist realism: is there no alternative. Winchester/ Washington: Zero Books, 2009.

Ghosts of my life: Writings on Depression, Hauntology and Lost Futures. London: Zero Books, 2014.

FOUCAULT, Michel. História da Sexualidade 1: A vontade de saber. 19ed. Rio de Janeiro: Graal, 1988.

Microfísica do Poder. 23ed. Rio de Janeiro: Graal, 1979.

O nascimento da biopolítica. São Paulo: Martins Fontes, 2008.

Segurança, território, população. São Paulo: Martins Fontes, 2008b.

The Mesh of Power. 2012 setembro 2012. Disponível em: https://www.viewpointmag.com/2012/09/12/the-mesh-of-power/ Acesso em: 1 jan 2017.

2004.

Vigiar e Punir: história da violência nas prisões. Petrópolis: Vozes,

FREUD, Sigmund. O Inconsciente. Edição Standard Brasileira das Obras Psicológicas Completas. v. XIV. Rio de Janeiro: Imago, 1996.

Luto e Melancolia. São Paulo: Cosac Naify, 2011.

Psicologia das massas e análise do eu e outros textos (1920-1923). São

Paulo: Companhia das Letras, 2011.

FROST, Gerald. Antony Fisher: champion of liberty. London: Profile Books, 2002.

GRANET, Marcel. O pensamento chinês. Rio de Janeiro: Contraponto, 2016.

THE GUARDIAN. Not even my wife knows: secret Donald Trump voters speak out. 3 de Março de 2016. Disponível em: https://www.theguardian.com/usnews/2016/mar/03/secret-donald-trump-voters-speak-out. Acesso em: 10 abr 2017.

GUATTARI, Felix; ROLNIK, Suely. Micropolítica: cartografias do desejo. Petrópolis: Vozes, 1986.

HABERMAS, Jürgen. The crisis of European Union. Cambridge: Polity Press, 2013.

HARDIN, Garrett. The Tragedy of the Commons. Science Magazine, 13 dezembro.1968: p.1243-8.

HARVEY, David. Cidades rebeldes: do direito à cidade à revolução urbana. São Paulo: Martins Fontes, 2014.

Neoliberalismo: história e implicações. São Paulo: Loyola, 2014.

O novo imperialismo. São Paulo: Loyola, 2004. (ver ano edição casa).

HAYEK, F. A. Law, legislation and liberty: A new statement of the liberal principles o f justice and political economy. v.3: The political order of afree people. London: Routledge, 1979.

JAMESON, Fredric. A new reading of Capital. Mediations: Journal of the marxist literary group. n.1, v.25, 2010. p.5-14. 
JAQUET, Chantal. A unidade do corpo e da mente. Belo Horizonte: Autêntica, 2011.

JUDIS, John B. The populist explosion: how the great recession transformed American and European politics. New York: Columbia Global Reports, 2016.

JUDT, Tony. Ill fares land. London: Penguin, 2013.

JULLIEN, François. Tratado da Eficácia. Lisboa: Instituto Piaget, 1996.

KAZIN, Michael. The Populist Persuasion. Ithaca/London: Cornel University, 1998.

KEHL, Maria Rita. Melancolia e Criatividade. In: FREUD, S. Luto e Melancolia. Trad. Marilene Carone. São Paulo, SP: Cosac Naify, 2011.

KLEIN, Naomi. A doutrina do choque: a ascensão do capitalismo de desastre. Rio de Janeiro: Nova Fronteira, 2008.

KOZICKI, Katya. Prefácio à edição brasileira. In: MOUFFE, Chantal. Sobre o Político. São Paulo: Martins Fontes, 2015.

KUZNETS, Simon. Economic Growth and Income Inequality. American Economic Review, 1955. p.1-28.

LACLAU, Ernesto. A glimpse of the future. In: MARCHART, Oliver; CRITCHLEY, Simon (eds). Laclau: a Critical Reader. London/New York: Routledge, 2014. A razão populista. São Paulo: Três Estrelas, 2013.

Emancipação e Diferença. Rio de Janeiro: Ed. UERJ, 2011.

New reflections on the revolution of our time. London/New York:

Verso, 1990.

. Politics and Ideology in Marxist Theory: capitalism, fascism, populism. Londres: NLB, 1977.

The rhetorical foundations of society. London: Verso, 2010.

; MOUFFE, Chantal. Hegemonia e estratégia socialista: por uma política democrática radical. São Paulo: Intermeios, 2015.

LAKOFF, George. The Political Mind: A Cognitive Scientist's Guide to Your Brain and Its Politics. New York: Penguin Books, 2009.

The Political Mind: why you can't understand a 21st-century politics with a 18th century brain. New York: Penguin Books, 2009.

LAKOFF, George; JOHNSON, Mark. Metaphors we live by. Chicago: Chicago University Press, 2013.

LLOYD, William Forster. Two Lectures on the Checks to Population . Oxford: Oxford University Press, 1833.

LOPES, Alice Casimiro; MENDONÇA, Daniel de; e BURITI, Joalindo A. A contribuição de Hegemonia e Estratégia Socialista para as ciências humanas e sociais. In: LACLAU, Ernesto; MOUFFE, Chantal. Hegemonia e Estratégia Socialista: por uma política democrática radical. São Paulo: Intermeios, 2015. p.7-32.

LORDON, Fréderic. A sociedade dos afetos: por um estruturalismo das paixões. São Paulo: Papirus, 2015.

MACHEREY, Pierre. The Productive Subject. 31 outubro de 2015. Disponível em: https://www.viewpointmag.com/2015/10/31/the-productive-subject/. Acesso em: 25 jul 2017.

MALINI, Fábio. Tecnopolítica: A viralidade indígena em rede e os modos de mobilização. 20 Abril 2017. Disponível em: http://midianinja.org/fabiomalini/ tecnopolitica-a-viralidade-indigena-em-rede-e-os-novos-modos-de-mobilizacao/ Acesso em: 10 mai 2017. 
MARCUSE, Herbert. Eros e Civilização: uma interpretação filosófica do pensamento de Freud. 8ed. Rio de Janeiro: Guanabara Kogan, 1999.

MARX, Karl. Manuscritos econômico-filosóficos. São Paulo: Boitempo, 2004.

O Capital: Livro 1. São Paulo: Boitempo, 2013.

MEANEY, Thomas; MOUNK, Yascha. What was democracy? The Nation, Junho 2014.

MIROWSKI, Philip; PLEHWE, Dieter. The road from Mont Pèlerin: the making of the neoliberal though collective. Massachusetts/London: Harvard University Press, 2009.

MORFINO, Vittorio. Plural Temporality: Transindividuality and the Aleatory Between Spinoza and Althusser. Leiden/Boston: Brill, 2014.

MOUFFE, Chantal. Agonistics. London: Verso, 2013.

. Sobre o Político. São Paulo: Martins Fontes, 2015.

The Democratic Paradox. London: Verso, 2000.

NUNES, Rodrigo. A vitória da obscenidade. Folha de São Paulo. 4 dezembro 2016. Disponível em: http://www1 folha.uol.com.br/ilustrissima/2016/12/1837803 -como-2016-levou-o-indizivel-ao-estrelato.shtml. Acesso em: 25 jul 2017.

. Entrevista: As manifestações renovarão os mecanismos existentes ou criarão novos? Cadernos IHU em Formação, n.46, 2014.

Entre Negri y Laclau: los límites de la multitud. Políticas de la Memória.

Anuario de Investigación e Información del CeDInCI, 16 (2015/2016).

Geração, acontecimento, perspectiva: pensar a mudança a partir do Brasil. Revista Nueva Sociedad, n.251, dez 2014.

PIGNARRE, Philippe; STENGERS, Isabelle. Capitalist Sorcery: breaking the spell. London: Palgrave Macmillan UK, 2007.

PIKETTY, Thomas. A economia da desigualdade. Rio de Janeiro: Intrínseca, 2015.

PROTEVI, John. Ontology, Biology, and History of Affect. In: BRYANT, Levi; SRNICEK, Nick; HARMAN, Graham. The speculative turn: continental materialism and realism. Melbourn: re.press, $2011 \mathrm{~b}$.

Political Affect: conecting the social and the somatic. Mineapolis/ London: University of Minesota Press, 2009.

Political Physics: Deleuze, Derrida \& the Body Politic. London/New

York: The Athlone Press, 2001.

RANCIÈRE, Jacques. A partilha do sensível: estética e política. São Paulo: Editora 34, 2005.

O Desentendimento. São Paulo: 34, 1996.

READ, Jason. A Genealogy of Homo-Economicus: Neoliberalism and the Production of Subjectivity. Foucault Studies, Fevereiro 2009. p.25-36.

The micro-politics of Capital: Marx and the prehistory of the present. New York: State University of New York, 2003.

The Production of Subjectivity: From Transindividuality to the Commons. New Formations: A Journal of Culture/Theory/Politics, n. 70, 2010.

ROBERTS, Alasdair. The logic of discipline: global capitalism and the architecture of governement. Oxford: Oxford University, 2010.

ROQUE, Tatiana. En quoi le capitalisme serait une axiomatique? Actes du Colloque de Cerisy-Deleuze: virtuel, machines et lignes de fuite. Trad. Alyne de Castro Costa. (no prelo) 2016. 
- Sobre a noção de diagrama: matemática, semiótica e as lutas minoritárias. Revista Trágica: estudos de filosofia da imanência 8, n.1, 2015. p.84-104.

ROSANVALLON, Pierre. The society of equals. Harvard: Harvard University Press, 2013.

RUNCIMANN, David. The confidence trap: a history of democracy in crisis from World War I to the present. Princeton: Princeton University Press, 2013.

SAFATLE, Vladimir. David Lynch ou a arte de construir estradas com ruínas, 2004. Disponível em: < http://p.php.uol.com.br/tropico/html/textos/1682,1.shl> . Acessado em: 20 de Julho de 2017.

O circuito dos afetos: corpos políticos, desamparo e o fim do indivíduo. Belo Horizonte: Autêntica, 2016.

SANTOS, Bernardo de Carvalho Tavares dos. O capitalismo axiomático de Deleuze e Guattari: sobre o sentido da ideia de "axiomática geral dos fluxos descoficados" elaborada em O Anti Étipo e Mil Platôs. Disponível em: http://www.ufscar.br/ semppgfil/wp-content/uploads/2012/05/1.pdf Acesso em 24 jan 2017.

SCHÄFER, Amir; STREECK, Wolfgang. Introduction: politics in the age of austerity. In: Politics in the age of austerity. Cambridge: Polity Press, 2013.

SIMONDON, Gilbert. El modo de existencia de los objectos técnicos. Buenos Aires: Prometeo Libros, 2007.

SPINOZA, Baruch. Obra completa II: correspondência completa e vida. São Paulo: Perspectiva, 2014. . Tratado Político. In: Obras Completas IV: (Breve) Tratado e outros escritos. São Paulo: Perspectiva, 2014.

Tratado Teológico-Político. In:

Teológico Político. São Paulo: Perspectiva, 2014. . Obra Completa III: Tratado SRNICEK, Nick; WILLIAMS, Alex. Inventing the Future: Postcapitalism and a World Without Work. London/New York: Verso, 2015.

STAVRAKAKIS, Yannis. The lacanian left: psychoanalysis, theory, politics. Edinburgh: Edinburgh University Press, 2007.

STENGERS, Isabelle. A cosmopolitical proposal. In: LATOUR, Bruno; WEIBEL, P. Making Things Public: Atmospheres of Democracy. Cambridge: MIT Press, 2005. p.994-1003.

STREECK, Wolfgang. As crises do capitalismo democrático. Novos Estudos (Cebrap), n.92, mar 2012. p.35-56.

TARDE, Gabriel. Monadologia e Sociologia e Outros Ensaios. São Paulo: Cosac Naify, 2007.

TOSCANO, Alberto. Fanaticism: on the uses of an idea. London: Verso, 2010. TSÉ-TUNG, Mao. Sobre prática e a contradição. Rio de Janeiro: Jorge Zahar, 2008.

TUPINAMBÁ, Gabriel. Sobre um projeto de psicanálise popular, ou: convém ser comunista para escutar o sofrimento social? Lavra Palavra. 7 outubro 2006. Disponível em: https://lavrapalavra.com/2017/04/19/sobre-um-projeto-depsicanalise-popular-ou-convem-ser-comunista-para-escutar-o-sofrimento-social/ Acesso em 20 abr 2017.

WALLERSTEIN, Immanuel. World-Systems Analysis: an introduction. Durham/ London: Duke University Press, 2004. 
YOVEL, Yirmiyahu. Spinoza and Other Heretics: The Adventures of Immanence. Oxford/Princeton: Princeton University Press, 1989b.

Spinoza and Other Heretics: The Marrano of Reason. Oxford/ Princeton: Princeton University Press, 1989a. 